Avaliação eletromiográfica de músculos da cintura escapular e braço durante a realizaçāo de exercícios com a extremidade distal do segmento fixa e carga axial controlada

Ribeirão Preto 2007 


\title{
Avaliação eletromiográfica de músculos da cintura escapular e braço durante a realização de exercícios com a extremidade distal do segmento fixa e carga axial controlada
}

\author{
Dissertação apresentada ao Departamento de \\ Biomecânica, Medicina e Reabilitação do Aparelho \\ Locomotor da Universidade de São Paulo para a obtenção \\ do título de Mestre. \\ Área de Concentração: Reabilitação \\ Orientadora: Profa. Dra. Anamaria Siriani de Oliveira \\ Co-orientadora: Profa. Dra. Débora Bevilaqua-Grossi \\ Colaboradores: Rodrigo de Andrade \\ Rodrigo Cappato de Araújo \\ Jaqueline Martins
}

Ribeirão Preto

2007 
AUTORIZO A REPRODUÇÃO E DIVULGAÇÃO TOTAL OU PARCIAL DESTE TRABALHO, POR QUALQUER MEIO CONVENCIONAL OU ELETRÔNICO, PARA FINS DE ESTUDO E PESQUI SA, DESDE QUE CITADA A FONTE.

Ficha Catalográfica

Tucci, Helga Tatiana

Avaliação eletromiográfica de músculos da cintura escapular e braço durante a realização de exercícios com a extremidade distal do segmento fixa e carga axial controlada. $108 \mathrm{p}$.

Dissertação de Mestrado, apresentada à Faculdade de Medicina de Ribeirão Preto da Universidade de São Paulo/USP - Programa de Pós-graduação em Ortopedia, Traumatologia e Reabilitação, Área de concentração: Reabilitação
1. Eletromiografia
2. Ombro
3. Carga axial controlada

4. Cadeia cinética

5. Superfície estável 
Um dia li um poema de Madre Tereza de Calcutá que dizia, entre outras coisas, que as pessoas mais necessárias são os pais e que a coisa mais bela é o amor. Hoje, mais do que nunca percebo e concordo com isso. Dedico esta dissertação aos meus pais Darci e Maria, por me ensinarem a não esmorecer diante das dificuldades, a ser otimista e buscar os meus ideais, a acreditar nas pessoas e por mostrarem que com respeito e trabalho podemos conquistar pessoas, trabalhos, vencer dificuldades e conseguir o nosso lugar ao sol. Dedico ao amor incondicional que recebi sem o qual provavelmente não teria chegado até aqui. Amo muito vocês!

Também dedico esta dissertação aos Meus irmãos Eduardo e Heloisa, pelo carinho, companheirismo, amizade, descontração e por primeiro me ensinarem que temos que dividir, aprender, sorrir, concordar, discordar sem discutir, lutar, ajudar e amar aqueles que convivemos, enfim, o primeiro aprendizado de uma vida em conjunto! 
Também dedico esta dissertação a uma pessoa que escolheu o ensinamento por profissão. Alguém que me ensinou a ter a dúvida como curiosidade maior e guia de caminho

para a pesquisa, alguém que me ensinou que trabalho dedicado rende frutos, que aprendizado não é apenas leitura, mas convívio, atenção às palavras, divisão de tarefas, esforço e determinação. Alguém que por muitas vezes deixou de ser orientadora para ser amiga e conselheira e, acima de tudo, alguém que acreditou que eu seria capaz de ser uma Mestrada. Dedico esta Dissertação a Profa. Dra. Anamaria Siriani de Oliveira. 
Agradeço a Deus, que me deu sabedoria para enxergar as oportunidades, por ter posto em meu caminho pessoas que ensinaram e que me auxiliaram e por ter sido meu maior refúgio nas horas de desespero e desilusão, quando me deu mais paciência e lucidez para sempre enxergar o lado bom das coisas.

Agradeço a minha família, que em sua maior parte esteve ao meu lado. Mas agradeço em especial a minha avó Maria Cioffi Tucci, por ter cuidado de mim enquanto meus pais trabalhavam. Foi ela, junto com os meus pais, a maior responsável pela minha educação e criação. Também agradeço aos meus avós Ernesto Gaspar e Antonia Gallo Gaspar por me ensinarem que a vida sempre vale a pena apesar dos obstáculos, por me ensinarem que o amor entre pessoas sempre existe e que nem sempre é expresso do jeito que queremos. Agradeço a minha madrinha Angela Maria Gaspar e ao meu tio Edson Gaspar pelo companheirismo e visão otimista da vida e por me ensinar que bom humor é fundamental como alicerce entre pessoas e como luz em dias difíceis.

Agradeço a Profa. Dra. Helena Maria André Bolini, primeira pessoa que parou para ouvir o meu interesse pela pesquisa e, com sua paciência e amor pelo que faz, me expôs a vida acadêmica. Agradeço também por ter sido a primeira pessoa que acreditou que eu tinha um potencial e que torceu por mim durante as provas de iniciação científica. Por ter me ensinado que pesquisa é dedicação, paixão pelo que faz e determinação. E, acima de tudo, por ter me ensinado que podemos ser educadores através do estabelecimento do respeito entre pessoas e não da exposição da diferença de graduação entre elas.

Como não poderia deixar de ser, agradeço aos docentes Prof. Ms. Gilberto Eiji Shiguemto, Prof. Ms. Carlos Grazziano, Prof. Dr. Wilton Rogério Lustri e Prof. Dr. Carlos Benatti Neto, meus professores de iniciação científica. Foi através da convivência com eles que formei a minha primeira base científica. Obrigada pelos ensinamentos!

Agradeço também a Lilian Ramiro Felicio e a Sabrina dos Santos Amorim, minhas companheiras de iniciação científica! A equipe foi tão boa e o companheirismo foi tão presencial que durou praticamente a graduação toda em duas iniciações científicas. Foi com elas que aprendi que discutir resultados de pesquisa não é fácil e que um grupo de trabalho não permanece e não cresce sem respeito.

Não poderia deixar de agradecer a Profa. Dra. Anamaria Siriani de Oliveira e a Profa. Dra. Débora Bevilaqua Grossi pelas profissionais exemplares que são, pela demonstração de perseverança e determinação, pela competência como docentes e pesquisadoras. Agradeço por terem me aberto as portas do LAPOMH (Laboratório da Análise da postura e do Movimento Humano). E, claro, pela convivência diária e longa, por tantas vezes terem sido amigas acima de docentes.

A minha equipe de trabalho, Rodrigo de Andrade, Rodrigo Cappato de Araújo e Jaqueline Martins, pessoas que formaram um grupo, trabalharam juntas, venceram desafios e acreditaram que poderiam realizar este projeto. Agradeço a todos, pois o trabalho de cada um foi fundamental. Ao Capatto pela determinação a afinco no que faz e ao Kinder (Rodrigo de Andrade) pelo trabalho dedicado e pelas boas risadas que ele provocava, pois através dele descobri que trabalho e diversão podem andar juntos e dar bons resultados e foi pela sua descontração que muitas vezes o trabalho incessante desta pesquisa percorreu caminhos mais fáceis e deu ânimo a este grupo nas horas 
de cansaço. Agradeço a Jaqueline, por ter me ensinado que ensinar nem sempre é fácil, mas sempre é prazeroso e que o maior ensinamento é o que se conquista e permanece na forma de aprendizado de vida.

Agradeço à família Antoniosi, que considero a minha segunda família, por sempre me acolherem, me respeitarem e me tratarem como tal. Adélio e Nadir, pessoas especiais e que são exemplos pra mim. A Adeliane, Alex e Patrícia, por sempre me acolherem e me respeitarem. Ao Alex e ao Adélio por confeccionarem alguns dos suportes que utilizei em minha pesquisa. Acima de tudo, agradeço à Angélica, que considero minha irmã de coração, pessoa sempre presente em minha vida, que me ensinou que amizade vale a pena, que deu risadas comigo, que compartilhou segredos, vitórias, conquistas, que enxugou minhas lágrimas quando precisei, que me aconselhou e, como todo amigo verdadeiro, puxou minhas orelhas e abriu meus olhos quando foi necessário. Uma pessoa que vale a pena conviver. Obrigado Lela!

Agradeço a Priscila E. S. Gianini, por ter sido amiga e conselheira, por me mostrar que as coisas valem à pena e por ter me ajudado nas horas em que achava que a esperança era artigo de luxo! Mas também agradeço pelas imensas horas de boas conversas e diversão regadas à refrigerante e brigadeiro! Necessidades básicas para comemorar coisas boas naquela república!

Agradeço a Lilian Ramiro Felicio pela amizade dedicada desde a graduação, pelo ombro amigo nas horas difíceis, pelos ensinamentos, pelo companheiro, pela motivação, pelas boas conversas, pelos conselhos em hora própria, enfim, por me oferecer uma amizade, que de tão especial, considero fraternal. Alguém em que compartilho minhas conquista e que busco motivação na sua determinação e competência. Alguém que quero por perto sempre. Adoro muito você!

Também não poderia deixar de agradecer a Thais Cristina Chaves. Uma amizade tão grande em tão pouco tempo, alguém que mostra a cada segundo o quanto vale a pena gostar do que faz e correr atrás dos seus sonhos. Alguém que me acolheu, ajudou, ensinou... Alguém que adoro e tenho uma enorme consideração, mais uma pessoa que me fez acreditar que amizade vale a pena! Também adoro você!

Também agradeço aos meus amigos de laboratório, minha família fora de Matão, donos do meu maior aprendizado em equipe e em pesquisa, amigos de horas difíceis e boas horas de churrasco! Obrigada Priscila E. S. Gianini, Lílian Ramiro Felício, Thaís Cristina Chaves, Jaqueline Martins, Vânia Fanelli, Rodrigo Cappato de Araújo, Rodrigo Andrade, Rodrigo Antunes Vasconcelos, Juliano Arakaki, Augusto Baffa, Daniel Martins Coelho, Rogério, Marcelo Saad, Letícia Melo de Souza, Harumi Martins Nagamine e Michelle Tannuri.

Tenho mais um motivo pra agradecer a Deus, ele me deu a oportunidade de encontrar em minha jornada muitas pessoas que considero amigas e, como não poderia deixar de ser, sempre me acolheram, ajudaram, respeitaram, ensinaram, me fizeram rir, demonstraram que confiar é possível e que amizade duradoura existe. Aos meus amigos que, de tão boa convivência, formam uma turma de longos anos! São eles: Angélica Antoniosi, Marcos Romano, Luiz Eurico de Linhares, Maria Cristina Ruiz, Leony Assaiante, Edvaldo Falcai, Sandra e Neto Chiozzini, Angela Maria Serrano, Celso Ruiz, Alba Chiozzini, Alexandre Tessi, Elisabete Ferreira da Costa, Edvaldo Scarpinati, Rogério e Ivete Gabriel, Ligiane Gardenchi, Odne Bambozzi, Valéria de Abreu, Carolina Salvini, Sandra Helena Bononi. 
Agradeço as minhas antes amigas de faculdade e hoje amigas de vida, Flávia Engelbrecht, Viviane Frigo Busolin Motta, Ana Lúcia Conde e Simone Paganelli. Agradeço à Sandra Bottesini Massocato, Fernanda Vieira, Tamara Baldini, Henrique Cestari de Paoli e Íris Beeke pela amizade e pela pronta ajuda. Agradeço ao Sr. Laércio Ardana, pelas infinitas vezes que me levou, juntamente com os pacientes, à Ribeirão Preto pelo ônibus municipal.

Aos meus amigos:

\section{Gratidão}

Pela amizade que você me devota, por meus defeitos que você nem nota... Por meus valores que você aumenta, por minha fé que você alimenta... Por esta paz que nós nos transmitimos, por este pão de amor que repartimos... Pelo silêncio que diz quase tudo, por este olhar que me reprova mudo... Pela pureza dos seus sentimentos, pela presença em todos os momentos... Por ser presente, mesmo quando ausente, por ser feliz quando me vê contente...

Por este olhar que diz: "amigo, vá em frente!"

Por ficar triste, quando estou tristonho, por rir comigo quando estou risonho...

Por repreender-me, quando estou errado, por meu segredo, sempre bem guardado...

Por seu segredo, que só eu conheço,

e por achar que apenas eu mereço...

Por me apontar pra Deus a todo o instante, por esse amor fraterno tão constante...

Por tudo isso e muito mais eu digo

"Deus te abençoe!"

(Autor Desconhecido)

Agradeço aos funcionários e docentes do Departamento de Biomecânica, Ortopedia e Reabilitação do Aparelho Locomotor e à Seção de Pós-Graduação, pelo apoio oferecido e pela paciência desprendida. Também agradeço ao CEMEQ - Centro de Métodos Quantitativos, pela realização da estatística deste trabalho.

Agradeço a minha banca, Profa. Dra. Stela Márcia Mattiello Gonçalves Rosa e Prof. Dr. Wilson Marques Júnior, por aceitarem fazer parte desta etapa da minha vida, por terem me recebido previamente e por terem oferecido suas contribuições.

Por fim, agradeço à Fapesp - Fundação de Amparo à Pesquisa do Estado de São Paulo pelo apoio financeiro oferecido (Processo $n^{\circ}$ 2003/13042-1) a Capes, pela bolsa Demanda Social que tornou possível a minha permanência no Mestrado e pelo Conselho Nacional de Desenvolvimento Científico e Tecnológico - CNPq, pela Bolsa Produtividade em Pesquisa (Processo $\left.n^{\circ} 119491 / 2004-4\right)$. 


\section{SUMÁRIO \\ Lista de Abreviaturas \\ Lista de Tabelas \\ Lista de Figuras \\ Lista de Símbolos \\ Resumo \\ Abstract}

2. Objetivo

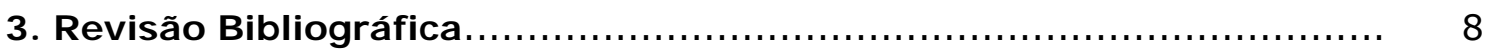

3.1 Classificação de exercícios para os membros superiores................... 8

3.2 Fatores que influenciam a relação Eletromiografia-força

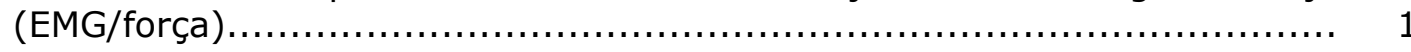

3.3 Estudos eletromiográficos sobre os exercícios push-up, bench-press e

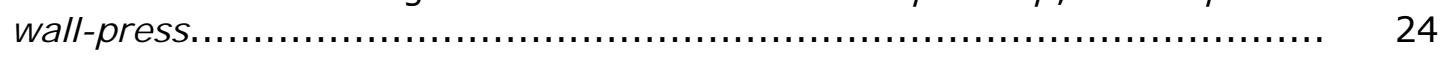

4. Materiais e Métodos........................................................ 40

4.1 Descrição da amostra...................................................... 40

4.2 Avaliação física................................................................ 41

4.3 Materiais Utilizados................................................... 41

4.4 Equipamento.................................................................. 42

4.4.1 Eletromiógrafo e Programa.................................... 42

4.4 .2 Eletrodos............................................................. 45

4.4.3 Célula de Carga e Condicionador de Sinais......................... 45

4.5 Superfície Estável.................................................... 48

4.6 Maca e Suportes para a realização dos exercícios...................... 48

4.7 Procedimento e Coleta de Dados......................................... 52

4.8 Exercícios Propostos...................................................... 56

4.9 Análise dos Dados...................................................... 59

4.10.Análise Estatística................................................... 60

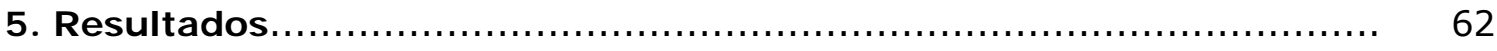

5.1 Comparação da atividade eletromiográfica dos músculos avaliados entre os exercícios realizados com $100 \%$ e $80 \%$ do esforço isométrico máximo...... 
5.2 Comparação da atividade eletromiográfica a $100 \%$ e $80 \%$ do torque isométrico máximo para um mesmo exercício.

5.3 Análise da porcentagem de ativação eletromiográfica nos exercícios wall-press, bench-press e push-up..............................................

5.4 Força produzida durante os exercícios wall-press, bench-press e pushup nos dois níveis de esforço isométrico...

6. Discussão

7. Conclusão.

8. Referência Bibliográfica

\section{Apêndice}

\section{Anexo}




\section{LISTA DE ABREVIATURAS}

\begin{tabular}{|c|c|}
\hline CCA & Cadeia Cinética Aberta \\
\hline $\mathrm{CCF}$ & Cadeia Cinética Fechada \\
\hline EMSC & Extremidade Distal Móvel sem Carga \\
\hline EMC & Extremidade Distal Móvel com Carga \\
\hline EFC & Extremidade Distal Fixa \\
\hline EFCA & Extremidade Fixa - Carga Axial \\
\hline EMCA & Extremidade Móvel - Carga Axial \\
\hline EMCR & Extremidade Móvel - Carga Rotacional \\
\hline EMSC & Extremidade Móvel - Sem Carga \\
\hline EMG & Eletromiografia \\
\hline SEMG & Sinal Eletromiográfico de Superfície \\
\hline PAUM & Potencial de Ação de Unidade Motora \\
\hline CIVM & Contração Isométrica Voluntária Máxima \\
\hline DBA & Distância Biacromial \\
\hline TS/SA & Quociente trapézio superior/serrátil anterior \\
\hline EFCA & Extremidade Fixa - Carga Axial \\
\hline ELCR & Extremidade Livre - Carga Rotacional \\
\hline EFCA & Extremidade Fixa - Carga Axial \\
\hline EFCR & Extremidade Fixa - Carga rotacional \\
\hline SENIAN & $\begin{array}{l}\text { Surface Electromyography for the Non-Invasive Assessment of Muscles } \\
\text { (Eletromiografia de Superfície para avaliação muscular não invasiva) }\end{array}$ \\
\hline RMS & Root Mean Square (raiz quadrada da média) \\
\hline WP & Wall-press \\
\hline $\mathrm{BP}$ & Bench-press \\
\hline PU & Push-up \\
\hline M & Músculo \\
\hline DA & Fibras Anteriores do Músculo Deltóide \\
\hline PM & Peitoral Maior \\
\hline BB & Bíceps Braquial \\
\hline TB & Tríceps Braquial \\
\hline TS & Fibras Superiores do Músculo Trapézio \\
\hline SA & Serrátil Anterior \\
\hline DP & Fibras Posteriores do Músculo Deltóide \\
\hline
\end{tabular}




\section{LISTA DE TABELAS}

Tabela 1. Médias e desvios-padrão dos dados antropométricos dos voluntários.................................................................

Tabela 2. Modo de colocação dos eletrodos segundo orientações da Recommendations for Surface Electromyography do Projeto SENIAN Hermes et al. (1999) e de Hintermeinster et al. (1998).....

Tabela 3. Valores médios e desvios-padrão obtidos da comparação entre os valores de RMS normalizados pela contração isométrica voluntária máxima dos músculos avaliados durante os exercícios wall-press, bench-press e push-up realizados com $100 \%$ do esforço isométrico máximo ( $n=15$ para DP e $n=20$ para os demais músculos). Unidade Arbitrária (U.A.).

Tabela 4. Valores médios e desvios-padrão obtidos da comparação entre os valores de RMS normalizados pela contração isométrica voluntária máxima dos músculos avaliados durante os exercícios wall-press, bench-press e push-up realizados com $80 \%$ do esforço isométrico máximo ( $n=15$ para DP e $n=20$ para os demais músculos). Unidade Arbitrária (U.A.)

Tabela 5. Valores médios e desvios-padrão obtidos da comparação entre os valores de RMS normalizados pela contração isométrica voluntária máxima dos músculos avaliados durante o mesmo exercício realizado com $100 \%$ e $80 \%$ do esforço isométrico ( $n=15$ para DP e $n=20$ para os demais músculos). Unidade Arbitrária (U.A.)...

Tabela 6. Valores médios e desvios-padrão obtidos da comparação entre a atividade eletromiográfica dos músculos estudados, referidas em valores de RMS normalizados, nos exercícios wall-press, bench-press e push-up com $100 \%$ e $80 \%$ do torque máximo. ( $n=15$ para DP e $n=20$ para os demais músculos). Unidade Arbitrária (U.A.)

Tabela 7. Porcentagem de atividade elétrica durante os exercícios wall-press, bench-press push-up, obtidas através de valores de RMS normalizados. Atividade mínima menor que $20 \%$, moderada entre $20 \%-40 \%$, alta entre $41 \%-60 \%$ e muito alta acima de $60 \%$. $(n=15$ para DP e $n=20$ para os demais músculos).

Tabela 8. Valores médios e desvio-padrão dos valores de carga obtidos durante os exercícios $(n=20)$.... 


\section{LISTA DE FI GURAS}

Figura 1. Equipamento Myosystem $\mathrm{Br}-1$ - Vista Frontal

Figura 2. Interface da aquisição de dados do programa Myosystem $\mathrm{Br}-1$ versão 2.9b., ilustrando o resultado de uma coleta de registro eletromiográfico e de esforço máximo durante o exercício benchpress.

Figura 3. Interface do processamento de dados do programa Myosystem $\mathrm{Br}-1$ versão $2.9 \mathrm{~b}$, ilustrando o processamento do sinal adquirido da porção anterior do músculo deltóide obtido durante o exercício bench-press....

Figura 4. A. Eletrodos de superfície simples diferencial face posterior. B. Superfície de contato do eletrodo...

Figura 5. A. Eletrodos de referência face posterior. B. Superfície de contato do eletrodo de referência.

Figura 6. Célula de carga modelo MM da Kratos Dinamômetros LTDA. com capacidade nominal de $100 \mathrm{kgf}$....

Figura 7. Condicionador de sinais modelo C 500 da Data Hominis do Brasil.

Figura 8. Interface de ajuste do feedback sonoro do programa Myosistem $\mathrm{Br}-1$ versão $2.9 \mathrm{~b}$.

Figura 9. Maca para realização do exercício bench-press: A. Furação para posicionamento da célula de carga. B. Célula de carga e superfície estável em posição de teste do exercício. C. Regulagem deslizante horizontal do suporte da maca. D. Regulagem deslizante vertical do suporte da maca....

Figura 10. Suporte com furação para regulagem de altura para célula de carga e plataforma estável utilizado para a realização do exercício wall-press...

Figura 11. Suporte de madeira para montagem do exercício push-up................

Figura 12. Vista lateral dos equipamentos para a execução do exercício push-up. A. Superfície Estável. B. Célula de Carga C. Suporte de madeira.........

Figura 13. Exercício wall-press realizado em superfície estável..................... 56

Figura 14. Exercício bench-press realizado em superfície estável................. 57

Figura 15. Exercício push-up realizado em superfície estável. 


\section{STA DE SÍ MBOLOS}

N.m newtom-metro

kg quilograma

m metro

$\mathrm{cm} \quad$ centrímetro

kgf quilograma-força

$\mathrm{mV} \quad$ milivolt

$\mathrm{Hz} \quad$ hertz 
TUCCI, H.T. Avaliação eletromiográfica de músculos da cintura escapular e braço durante a realização de exercícios com a extremidade distal do segmento fixa e carga axial controlada. Dissertação (Mestrado) - Faculdade de Medicina de Ribeirão Preto, Universidade de São Paulo, Ribeirão Preto.

O objetivo desta pesquisa foi avaliar e comparar a atividade eletromiográfica de sete músculos da cintura escapular e braço durante a realização dos exercícios wall-press, bench-press e push-up sobre uma superfície estável e com carga axial controlada em dois níveis de esforço isométrico, um máximo (100\%) e outro submáximo $(80 \%)$. Os exercícios foram realizados com o braço em $90^{\circ}$ de flexão no plano sagital, $0^{\circ}$ de extensão do cotovelo e $90^{\circ}$ de flexão da mão. Vinte voluntários do sexo masculino, saudáveis, destros e sem história de trauma no membro superior participaram da pesquisa. Os registros eletromiográficos e de força foram adquiridos, respectivamente, por sete canais para eletromiograma e por um canal auxiliar de um sistema de aquisição simultânea, ganho total de 50 vezes, 12 bits de faixa de resolução dinâmica e freqüência de amostragem por canal de $4 \mathrm{KHZ}$. Os sinais mioelétricos foram captados por eletrodos ativos simples diferencial, ganho de 20 vezes, impedância de entrada de $10 \mathrm{G} \Omega$ e CMRR mínimo de $130 \mathrm{~dB}$, colocados nos músculos serrátil anterior, porção anterior e posterior do músculo deltóide, porção clavicular do peitoral maior, fibras superiores do trapézio, cabeça longa do bíceps e tríceps braquial. Os exercícios foram realizados aleatoriamente, nos dois níveis de esforço isométrico, com intervalados entre si por 5 minutos. Os voluntários realizaram três repetições de cada exercício, com duração de 6 segundos cada, intervaladas entre si por 1,5 minutos e manutenção da força dentro dos valores previamente definidos, orientadas por um feedback sonoro. Os sinais brutos foram filtrados por um passa faixa de $20-500 \mathrm{~Hz}$, derivando os valores de amplitude eletromiográfica pelo cálculo da Root Mean Square (RMS). Os valores de RMS foram normalizados pelo valor máximo obtido de três contrações isométricas voluntárias máximas obtidas em prova de função muscular. A comparação dos valores normalizados entre os três exercícios nos dois níveis de esforço isométrico e entre o mesmo exercício nos dois níveis de esforço isométrico foi realizada através do Modelo Linear de Efeitos Mistos, com nível de significância de $5 \%$. Os valores normalizados de RMS dos músculos estudados, em valores percentuais, foram usados para graduar o nível de atividade elétrica obtido em cada exercício. Os resultados demonstraram que houve uma diferença nos valores de RMS normalizados dos músculos avaliados nas comparações feitas entre os três exercícios, não confirmando a hipótese inicial deste trabalho, pois os dois níveis de esforços isométricos não foram capazes de influenciar a resposta eletromiográfica. Diferenças entre amplitudes de ativação normalizadas foram constatadas, variando entre os níveis mínimo e alto. O bench-press gerou maiores níveis de atividade eletromiográfica para a maioria dos músculos, possivelmente pelo maior esforço isométrico realizado. $O$ wall-press gerou maior atividade eletromiográfica para a maioria dos músculos quando comparado ao push-up, apesar do esforço isométrico gerado ser menor. Este trabalho concluiu que, apesar de exercícios com carga axial, mesmo com esforço isométrico controlado, causaram diferentes níveis de atividade eletromiográfica nos músculos avaliados.

Palavras-chave: eletromiografia, ombro, carga axial controlada, cadeia cinética, superfície estável. 
TUCCI, H.T. Electromyographic evaluation of scapular girdle and arm muscles during exercises with fixed distal extremity of the segment and controlled axial load. Dissertation (Master's) -Ribeirão Preto School of Medicine, University of São Paulo, Ribeirão Preto.

The purpose of this research was to investigate if biomechanically similar exercises produce similar myoelectric activation when the same level of maximal isometric effort is produced. Twenty volunteers participated in the study. All volunteers were right-handed, healthy men with no history of previous upper limb trauma. Electromyographic (EMG) recordings were obtained using a seven-channel simultaneous acquisition system, with gain of 50,12 bit A/D converter board with a 4 $\mathrm{KHz}$ frequency. To monitor produced force, a load cell was attached through an auxiliary channel and force recording was accomplished simultaneously with the acquisition of EMG signal. Myoelectric signals were obtained using simple differential electrodes, with gain of 20, input impedance of $10 \mathrm{G} \Omega$ and minimum CMRR of $130 \mathrm{~dB}$, placed on the serratus anterior, posterior and anterior deltoid, clavicular portion of the pectoralis major, upper trapezius, and biceps and triceps brachii muscles, following the European Recommendations for Surface Electromyography by SENIAM project, and instructions by Hintermeinster et al. (1998). EMG signals were recorded while performing push-up, bench-press, and wall-press exercises at different force levels $(100 \%$ and $80 \%$ maximum isometric effort) with the dominant upper limb supported on a stable surface. Exercises were randomly performed with five-minute intervals between each exercise. Volunteers performed three repetitions of each exercise, each lasting six seconds, with 1.5-minute intervals, and maintaining the force within previously determined values, guided by audio feedback. Raw EMG signals were filtered by a $20-500 \mathrm{~Hz}$ pass-band in order to derivate EMG amplitude values by intervals calculating the Root Mean Square (RMS). RMS values were normalized by the maximum value obtained in three maximal voluntary isometric contractions during muscle testing. Normalized values were compared between the three exercises at both torque levels and between the same exercise at both isometric effort levels through the mixed-effects linear model, with a $5 \%$ level of significance. Normalized RMS values of the studied muscles (\%) were used to rank the level of electric activity obtained during each exercise. Results indicate that maximal isometric effort levels had no influence on results from the comparison of EMG activity in any of the proposed exercises. Differences between normalized activation amplitudes were observed. However, the values reached levels between minimal and high, that is, under $60 \%$ of the activity generated during maximal voluntary isometric contraction. This study concludes that biomechanically comparable exercises did not necessarily produce similar EMG activity, in spite of controlling isometric effort. Moreover, exercises were capable of generating different EMG activity levels in the evaluated muscles. Therefore, such exercises are indicated for different rehabilitation program phases.

Keywords: electromyography, shoulder, controlled axial load, kinetic chain, stable surface. 


\section{"Toda glória advém de se ousar começar"}

Eugene F. Ware 


\section{I ntrodução}

Os termos cadeia cinética aberta (CCA) e cadeia cinética fechada (CCF), utilizados para classificar exercícios terapêuticos, foram originariamente derivados da engenharia mecânica e posteriormente adaptado ao corpo humano (RIVERA, 1994). Ao definir esta terminologia, Steindler (1955) classificou como exercícios em CCA aqueles em que a extremidade distal do segmento move-se livremente e sem restrições e como exercícios em CCF aqueles nos quais a extremidade distal do segmento está fixa em um suporte imóvel, sendo que o movimento em uma articulação produziria movimento nas demais.

Apesar da maioria dos clínicos terem uma boa compreensão de como empregar os termos CCA e CCF, existem alguns exercícios que não contemplam estas categorias e, portanto, constituem uma "área cinza" entre CCA e CCF (DAVIES, 2000). De acordo com Di Fábio (1999), os termos CCA e CCF podem criar diversas interpretações clínicas por serem usados para classificar exercícios e não o movimento realizado durante o exercício Por existirem controvérsias a respeito da utilização desta terminologia, outras classificações têm sido propostas (DILLMAN; MURRAY; HINTERMEISTER, 1994; BLACKARD; JENSEN; EBBEN，1999; DIFÁBIO，1999).

Dillman, Murray e Hintermeister (1994) propuseram um sistema de classificação para exercícios baseado na condição da extremidade, se fixa ou móvel e na presença ou ausência de carga na extremidade distal do segmento, criando as categorias de exercício extremidade móvel sem carga externa (EMSC); extremidade móvel com carga externa (EMC) e extremidade fixa com carga externa (EFC). Estes autores sugeriram que exercícios de mesma classificação, realizados com cargas similares produziriam níveis de atividade eletromiográfica semelhantes para músculos motores primários. Blackard, Jensen e Ebben (1999) também encontraram atividade eletromiográfica semelhante em exercícios biomecanicamente comparáveis. Entretanto, os autores sugerem que pesquisas futuras deveriam definir as articulações 
envolvidas no movimento e analisar a carga externa, que poderia ter mais influência na atividade eletromiográfica que a condição da extremidade.

Exercícios em cadeia cinética fechada (CCF), que normalmente envolvem sustentação de peso ou carga de compressão axial, têm ganhado popularidade entre os clínicos durante programas de reabilitação do ombro (LEAR; GROSS, 1998; DECKER et al., 1999; UHL et al., 2003; LUDEWIG et al., 2004). Estes exercícios têm sido considerados mais seguros e favoráveis ao estímulo de proprioceptores (LEPHART; HENRY, 1996; WILK; ARRIGO; ANDREWS，1996; KIBLER; LIVINGSTON, 2001). Além disso, exercícios em CCF realizados com carga axial favorecem a congruência articular, diminuem as forças de cisalhamento e promovem a estabilidade dinâmica da articulação através da coativação muscular (LEPHART; HENRY, 1996).

Algumas pesquisas sugerem a inclusão destes exercícios na fase inicial do tratamento (KIBLER; LIVINGSTON; BRUCE，1995; WILK, ARRIGO, ANDREWS, 1996) enquanto outras recomendam seu uso em fases tardias (DILLMAN; MURRAY; HINTERMEISTER, 1994; STONE et al., 1993). Os exercícios wall-press, bench-press e push-up, freqüentemente utilizados em protocolos de reabilitação (LEAR; GROSS; 1998; UHL, et al., 2003; LUDEWIG et al., 2004) e em treinamento da performance recreacional ou atlética (GOUVALI; BOUDOLOS, 2005; LEHMAN, 2005; COGLEY et al., 2005), são exemplos deste tipo de exercício. No entanto, a inclusão de exercícios em CCF na reabilitação pode estar associada com a carga imposta à articulação, o que pode favorecer um exercício em relação ao outro no decorrer do protocolo de reabilitação. Além disso, limitadas informações sobre a demanda muscular e a carga imposta ao ombro durante os exercícios não deixa claro em que fase do programa de reabilitação eles deveriam ser incluídos (UHL et al., 2003).

Embora a carga seja um dos possíveis fatores que causam modificação do sinal eletromiográfico, a maioria das pesquisas, ao comparar a atividade eletromiográfica, utilizou o mesmo valor de carga para diferentes exercícios (DILLMAN, MURRAY, HINTERMEISTER, 1994; BLACKARD, JENSEN, EBBEN, 1999), empregou apenas um valor de esforço isométrico (OLIVEIRA, CARVALHO; DE BRUM, 2006; OLIVEIRA et al., 
2006) ou considerou apenas o peso corporal como carga (LEAR; GROSS, 1998; UHL et al., 2003; LUDEWIG et al., 2004). Em relação ao torque isométrico máximo, as pesquisas de Oliveira et al. (2006) e de Oliveira, Cardoso e De Brum (2007), avaliaram a influência desta variável na atividade eletromiográfica. Entretanto, estes autores não avaliaram as possíveis alterações que diferentes porcentagens do torque isométrico poderiam causar na atividade eletromiográfica, visto que esta variável pode influenciar a atividade muscular.

Apesar da eletromiografia de superfície não ser considerada uma medida direta de força muscular, têm-se conhecimento que a variação da força empregada causa alterações na amplitude do sinal eletromiográfico (BASMAJIAN; DE LUCA, 1985). Entretanto, pesquisas demonstram que não existe um consenso a respeito de uma possível relação linear entre o sinal eletromiográfico e a força muscular (LAWRENCE; DE LUCA, 1983; WOODS; BIGLAND-RITCHIE, 1983; SOLOMONOV et al., 1990; PERRY; BECKEY, 1991), pois a variação no comprimento muscular, na velocidade ou no tipo de contração durante um determinado exercício pode causar alterações nesta relação (HECKATHORNE, CHILDRESS, 1981). Por outro lado, se os diferentes fatores que influenciam o sinal eletromiográfico forem controlados, uma medida indireta da força muscular pode ser obtida (MCDONAGH; DAVIES, 1984), sendo que maiores amplitudes eletromiográficas durante um exercício podem ser um indicativo de uma maior produção de força muscular.

Dessa forma, pesquisas que considerem o questionamento sobre a classificação de exercícios para o membro superior e a influência da carga na atividade eletromiográfica são importantes, pois a análise de quanto um determinado exercício é capaz de ativar um músculo ou um grupo muscular torna mais claro o seu uso na prática clínica (MOSELEY et al., 1992; UHL et al., 2003), já que a musculatura do complexo articular do ombro atua de maneira significativa na estabilidade desta articulação (LEAR; GROSS, 1998; OLIVEIRA et al., 2006).

Assim sendo, comparar a atividade elétrica de músculos da cintura escapular e braço nos exercícios wall-press, bench-press e push-up, realizados com a extremidade 
distal do segmento fixa em superfície estável e com carga axial controlada, ou seja, classificados em uma mesma categoria, de acordo com a condição da extremidade e direção da carga possui relevância, visto que exercícios biomecanicamente comparáveis produzem níveis de atividade eletromiográfica semelhantes quando realizados com a mesma condição de extremidade e com valor de esforço isométrico semelhante. 
"A verdadeira viagem de descobriment o não consiste em procurar novas paisagens, mas em ter novos olhos"

Marcel Proust 


\section{Objetivo}

O objetivo desse estudo foi avaliar e comparar a atividade eletromiográfica de sete músculos da cintura escapular e braço durante a realização dos exercícios wall-press, bench-press e push-up realizados sobre uma superfície estável e com carga axial controlada em dois níveis de esforço isométrico, um máximo e um submáximo. 
"Uma coletânea de pensamentos deve ser uma farmácia moral, onde se encontrem remédios para todos os males"

Voltaire

\section{Voltaire}

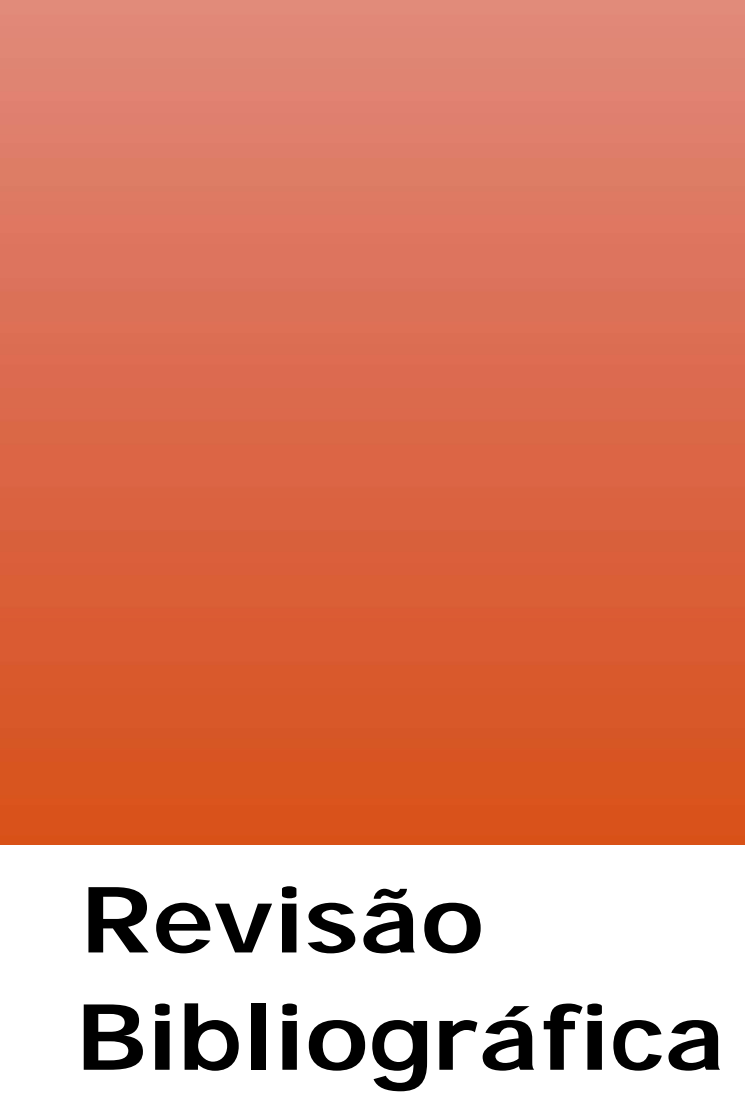




\section{Revisão Bibliográfica}

\subsection{Classificação de exercícios para os membros superiores}

O primeiro conceito sobre cadeia cinética teve origem na engenharia mecânica e, em 1955, Steindler fez uma adaptação deste conceito à biomecânica, sugerindo que cada membro do corpo poderia funcionar como uma porção de uma cadeia rígida em um sistema conectado por articulações, definindo os movimentos humanos em cadeia cinética aberta (CCA) e cadeia cinética fechada (CCF) (RIVIERA, 1994). O conceito CCA é empregado para descrever movimentos nos quais o segmento distal da extremidade é livre para mover-se enquanto que CCF é empregado para definir movimentos nos quais a extremidade distal do segmento é fixa, com uma resistência externa que impede ou restringe o movimento, sendo que o movimento em uma articulação produz movimento nas demais articulações da extremidade (STEINDLER, 1955).

Steindler (1955) definiu três possíveis condições para um movimento em CCF. A primeira delas é uma condição raramente observada em movimentos humanos, considerada absolutamente fechada, na qual não há nenhum movimento na extremidade distal ou proximal do segmento. Outra condição considerada CCF é aquela na qual uma resistência externa resulta em um movimento do segmento proximal sobre o segmento distal fixo e uma terceira condição acontece quando a resistência externa resulta em um movimento no segmento distal da extremidade (STEINDLER, 1955).

Porém, Steindler (1955) relata que classificar exercícios em CCA e CCF pode ser difícil, pois muitos exercícios podem ser considerados uma combinação destes dois termos. Panariello (1991) concorda com Steindler sobre a dificuldade em classificar os exercícios apenas em CCA e CCF e, ao avaliar este conceito, sugere a existência de uma "área cinza" entre estas definições, ou seja, uma área intermediária que possui características biomecânicas e fisiológicas tanto de exercícios em CCA quanto em CCF. 
A definição da "área cinza" surgiu durante a análise das diferenças existentes entre um treinamento em CCF usando pesos livres em comparação a um treinamento com equipamentos que promovem movimentos considerados em CCF. Panariello (1991) diz que, apesar de considerar os movimentos realizados em equipamentos como abrangendo movimentos que variam entre cadeia cinética aberta e fechada, optou por defini-los como exercícios em CCA porque o equipamento elimina os efeitos do peso e do equilíbrio corporal, apesar do apoio oferecido à extremidade distal do segmento.

No entanto, muitos exercícios realizados sem o auxílio de um equipamento também podem ser classificados nesta "área cinza" (DILLMAN, MURRAY; HINTERMEISTER, 1994). Exemplos destas atividades para a extremidade superior são a natação, o remo e certas modalidades de ginástica olímpica, assim como a marcha é um exemplo para a extremidade inferior (WILK; ARRIGO; ANDREWS, 1996).

Apesar dos clínicos terem uma boa compreensão sobre CCA e CCF, estes termos começaram a ser questionados na década de 1990 devido às controvérsias relacionadas às variadas interpretações que pesquisadores e clínicos possuem a respeito desta terminologia (DAVIES, 2000). Para exemplificar possíveis discordâncias, Harbst e Wilder (2000) utilizaram como exemplo os movimentos de flexão e extensão do joelho, feitos com o indivíduo sentado e com o movimento partindo da posição de $90^{\circ}$ de flexão do joelho no sentido da completa extensão. Alguns clínicos poderiam classificar estes exercícios como sendo em CCA enquanto outros poderiam considerálo como um exercício em CCF se carga fosse colocada na extremidade distal do segmento ou, uma outra interpretação possível, seria a de que, com ou sem carga, o exercício é em CCA, já que a extremidade distal do segmento move-se independente da presença ou ausência de carga (HARBST; WILDER, 2000).

Assim sendo, novos conceitos e sistemas de classificação foram propostos na literatura (PANARIELLO, 1991; GRAY; PETERSON; BRYANT, 1992; DILLMAN; MURRAY; HINTERMEISTER, 1994; LEPHART; HENRY, 1996; BLACKARD; JENSEN; EBBEN, 1999).

Gray, Peterson e Bryant (1992) mantiveram os termos CCA e CCF, fazendo algumas adaptações à descrição dos movimentos. Estes autores classificam um 
exercício em CCA como um sistema no qual o segmento distal permanece livre e o movimento realizado por ele é isolado, ocorrendo em um único plano de movimento. Se um movimento for multiplanar, com o segmento distal fixo e com o conjunto de segmentos envolvidos suportando algum tipo de peso, eles são considerados exercícios em CCF. A adaptação proposta pelos autores começa a enfatizar a necessidade de uma análise mais detalhada do movimento articular, ou seja, deixa de classificar um exercício apenas considerando a condição da extremidade e a presença ou ausência de carga e sugere classificá-lo de acordo com as diferenças biomecânicas que estas duas condições possam produzir durante um exercício.

Com base nas divergências existentes sobre os termos CCA e CCF, Dillman, Murray e Hintermeister (1994) propuseram uma nova terminologia para classificar os exercícios, levando em consideração a condição da extremidade, se fixa ou móvel e a carga imposta, se presente ou ausente. Assim, a terminologia inclui 3 categorias, já que a condição extremidade fixa e sem carga não é possível. A primeira delas é aquela que inclui atividades realizadas com a extremidade distal fixa e com presença de carga externa (EFC), a segunda é aquela em que extremidade distal é móvel e com carga externa (EMC) e a terceira condição é a extremidade distal móvel e sem carga (EMSC). As condições EFC e EMSC corresponderiam aos extremos de CCF e CCA, respectivamente, e o termo EMC seria a "área cinza" da classificação de Panariello. Para prover base quantitativa a esta nova proposta, Dillman, Murray e Hintermeister (1994) fizeram um estudo de caso que comparou a atividade eletromiográfica produzida durante exercícios para o ombro, analisando a hipótese que exercícios com mesma carga e mecânica de movimento semelhante produziriam atividade eletromiográfica similar em grupos musculares primários. Seus resultados demonstraram que os exercícios EFC e EMC produziram atividade muscular comparável. Dessa forma, Dillman, Murray e Hintermeister (1994) sugeriram que os exercícios deveriam ser definidos com base na análise biomecânica e na quantificação da carga imposta ao segmento ao invés de serem classificados como CCA e CCF. 
Blackard, Jensen e Ebben (1999) realizaram um estudo que comparou a atividade eletromiográfica durante exercícios considerados biomecanicamente comparáveis, utilizando a classificação proposta por Dillman, Murray e Hintermeister (1994). Os exercícios analisados foram o push-up, o bench-press com carga e o bench-press sem carga. Os resultados obtidos demonstraram que exercícios com diferente condição de extremidade e mesma carga (push-up e bench-press com carga) apresentaram atividade eletromiográfica similar em músculos motores primários enquanto exercícios com mesma condição da extremidade e diferente carga (benchpress com carga e bench-press sem carga) apresentaram diferentes valores de atividade eletromiográfica em músculos motores primários. Sendo assim, Blackard, Jensen e Ebben (1999) concluíram que classificar uma atividade em relação à presença ou ausência de carga é mais importante do que descrevê-la em relação à condição da extremidade, concordando com a classificação proposta por Dillman, Murray e Hintermeister (1994).

Semelhante a Dillman, Murray e Hintermeister (1994), Lephart e Henry (1996) propuseram um novo sistema para definir o movimento humano, denominado Sistema de Classificação Funcional, que compreende exercícios destinados à extremidade superior, classificados de acordo com características funcionais e ações neuromusculares comuns. Este sistema incorporou outras considerações além da condição da extremidade e da presença ou ausência de carga aplicada, sendo elas a direção da carga, se axial ou rotacional; a magnitude da resistência (alta velocidadebaixa resistência ou baixa resistência-alta velocidade), a ação muscular (co-contração, aceleração ou desaceleração) e a presença ou ausência de movimento articular.

Este Sistema de Classificação Funcional inclui quatro condições. A primeira delas é condição extremidade fixa - carga axial (EFCA), que inclui exercícios em baixa velocidade, capazes de gerar uma força de reação neuromuscular ativa ou reativa e uma ação muscular de co-contração, aceleração ou desaceleração. Exercícios definidos nesta categoria são similares aos exercícios de sustentação de peso e as vantagens associadas a este tipo de exercício é a co-contração dos pares de força musculares, 
estabilização muscular dinâmica, compressão articular, propriocepção e pequena força de cisalhamento, todas resultantes da carga axial. O slide board (prancha de deslizamento) e o push-up são exemplos de atividades que podem ser classificadas nesta categoria (LEPHART; HENRY, 1996).

A segunda condição é a extremidade móvel-carga axial (EMCA), que inclui exercícios com velocidade de movimento variável e ação muscular de co-contração, aceleração ou desaceleração. São atividades que promovem estabilização muscular dinâmica, co-contração de pares de força muscular, compressão articular, pequena força de cisalhamento e ativação de músculos motores primários. Inclui exercícios como a protração/retração escapular e o bench-press (LEPHART; HENRY, 1996).

A condição extremidade móvel-carga rotacional (EMCR) inclui exercícios com magnitude de carga e velocidade de movimento variáveis, produzindo uma ação muscular de coativação, aceleração ou desaceleração. São atividades que promovem estabilidade articular, ativação dos músculos motores primários e movimentos cinemáticos funcionais, visto que a maioria dos movimentos para a extremidade superior é realizada com a extremidade móvel e com carga rotacional. Inclui exercícios isocinéticos em uma diagonal funcional ou exercícios para o ombro em equipamentos multiaxiais (LEPHART; HENRY, 1996).

A última condição proposta pelo Sistema de Classificação Funcional é a extremidade móvel-sem carga (EMSC), que compreende atividades sem carga e movimentos passivos ou ativos com velocidade variável, com o objetivo de promover movimentos funcionais e sensibilidade de posicionamento articular. Promovem uma ação muscular de aceleração ou desaceleração. São atividades que promovem ativação da musculatura no sentido proximal-distal, baixa atividade muscular sem resistência e especificidade funcional. Exercícios passivos ou ativos que compreendem a orientação cognitiva e o treinamento do posicionamento articular fazem parte desta classificação (LEPHART; HENRY, 1996).

Segundo Lephart e Henry (1996), cada condição proposta neste sistema de classificação funcional inclui aspectos específicos do sistema neuromuscular 
necessários para restaurar a estabilidade funcional do complexo articular do ombro, tornando mais específica a elaboração de um protocolo de reabilitação. Outra consideração feita pelos autores é que o conhecimento das condições neuromusculares e biomecânicas relacionadas a cada condição faz com que o clínico possa elaborar atividades adequadas a cada estágio de reabilitação.

Apesar das novas classificações de exercícios propostas na literatura, Di Fábio (1999) relata que para desenvolver um programa de reabilitação funcional os clínicos devem compreender a função de uma cadeia cinética, ou seja, devem ter em mente que ela atua como uma unidade funcional integrada e interdependente que deve associar o movimento à especificidade da tarefa, favorecendo a prática clínica. Dessa forma, o protocolo de reabilitação deve conter exercícios que sejam capazes de produzir um fortalecimento muscular associado a uma eficiência neuromuscular, de forma que o indivíduo possa adquirir habilidade em gerar força e ativar a musculatura agonista, antagonista e sinergista em um padrão que possa produzir um movimento eficiente (CLARK, 2000).

Desse modo, Di Fábio (1999) diz que uma terminologia talvez não consiga classificar de maneira adequada todos os exercícios e que a elaboração de novas terminologias acabaria criando novos "jargões" que continuariam a não oferecer uma descrição clara e útil dos exercícios empregados na reabilitação ou na prática esportiva ou recreacional.

\subsection{Fatores que influenciam a relação Eletromiografia- força (EMG/ força)}

A eletromiografia de superfície, ferramenta utilizada para registrar potenciais elétricos de unidades motoras oriundos de fibras musculares, tem sido utilizada em vários estudos como uma medida indireta da força muscular. Entretanto, a relação entre a amplitude eletromiográfica registrada e a força gerada ainda é controversa na literatura (BASMAJIAN; DE LUCA, 1985). Estudos demonstram que não existe um consenso a respeito de uma possível relação linear entre o sinal eletromiográfico e 
força muscular. Perry e Beckey (1981) demonstraram que tarefas isométricas podem gerar uma relação eletromiografia-força aproximadamente linear. Já o estudo de Lawrence e De Luca (1983) demonstrou uma relação linear entre a atividade eletromiográfica e força gerada em músculos pequenos, como os interósseos dorsais e o abdutor do polegar, enquanto que em músculos maiores, como o bíceps braquial, tríceps braquial, deltóide e sóleo, esta relação não é claramente linear. O estudo de Woods e Bigland-Ritchie (1983) e de Solomonov et al. (1990) também encontraram resultados semelhantes, ou seja, uma relação linear entre EMG-força em músculos pequenos e não linear em músculos maiores.

Vários fatores podem contribuir para as incertezas em quantificar a amplitude do sinal eletromiográfico em valores de força muscular. De Luca (1997) diz que estudos sobre a relação entre o sinal eletromiográfico de superfície (SEMG) e a força muscular devem considerar fatores fisiológicos, anatômicos e técnicos, sendo os técnicos possíveis de controle enquanto os fisiológicos só podem ser considerados ou imaginados (DE LUCA, 1997). Para melhor descrevê-los, De Luca (1997) os agrupou em fatores causais, intermediários e determinantes, sendo os causais subdivididos em intrínsecos e extrínsecos.

Segundo De Luca (1997), os fatores intrínsecos não podem ser controlados por estarem relacionados às características fisiológicas, anatômicas e bioquímicas dos músculos. Entretanto, os fatores extrínsecos, por estarem associados à estrutura e colocação dos eletrodos, podem ser amenizados se técnicas adequadas de registro e processamento forem empregadas (DE LUCA, 1997).

Além disso, os fatores causais influenciam os fatores intermediários, que são fenômenos físicos e fisiológicos representados pelo tipo de filtro passa-faixa do eletrodo, pelo volume de detecção do eletrodo, pela superposição de potenciais de ação, pelo crosstalk (captação de sinal elétrico de músculos adjacentes) e pela velocidade de condução dos potenciais de ação (DE LUCA, 1997). Por fim, os fatores determinantes, que são influenciados pelos fatores intermediários possuem uma relação direta com o sinal eletromiográfico e com a força muscular por estarem 
relacionados com a atividade, disparo, recrutamento e detecção de unidades motoras, interação entre as fibras musculares e a força de contração (DE LUCA, 1997).

O sinal eletromiográfico é obtido através de uma somatória de potenciais de ação de diferentes unidades motoras (PAUM) na área de captação do eletrodo de deteç̧ão e, dessa forma, a distância das fibras musculares avaliadas em relação ao eletrodo é importante visto que quanto maior a distância, menor será a contribuição do potencial de ação gerado na amplitude do sinal eletromiográfico (BASMAJIAN; DE LUCA, 1985). Sendo assim, características individuais como a espessura da pele e do tecido subcutâneo influenciam a captação do sinal eletromiográfico. Além disso, o crosstalk (captação de sinal elétrico de músculos adjacentes) é outro fator que pode influenciar na relação EMG-força, visto que a captação de sinal elétrico de músculos vizinhos aumenta a amplitude do sinal eletromiográfico, não significando aumento de força muscular (DE LUCA, 1997).

A presença de cocontração muscular também deve ser considerada quando se estuda uma relação EMG-força, pois a atividade simultânea de músculos agonistas e antagonistas pode diminuir a amplitude do sinal eletromiográfico em conseqüência da distribuição de força muscular (BASMAJIAN; DE LUCA, 1985). Entretanto, Alkner, Tesch e Berg (2000) acreditam que uma baixa ativação da musculatura antagonista não seja suficiente para interferir na relação EMG-força.

A proporção de fibras do tipo I e do tipo II em um músculo é variável e pode interferir na relação EMG-força, sendo que a predominância de um tipo de fibra em relação a outra é dependente da sua função, ou seja, se ele é um músculo fásico ou tônico (KUKULKA; CLAMANN, 1981). A relação PAUM-twich (tensão gerada em uma fibra muscular após um único potencial de ação) é um dos fatores que podem influenciar a relação EMG-força. Fibras do tipo I são oxidativas, possuem menor diâmetro e geram um twich de contração lento (contração de baixa tensão com longa duração) em relação às fibras do tipo IIa glicolíticas ou IIb oxidativas-glicolíticas, que possuem um diâmetro maior e geram um twich rápido (contração de alta tensão e curta duração), ou seja, as fibras de twich lento geram menores valores de amplitude 
eletromiográfica em relação às fibras de twich rápido (POLGAR et al., 1973). Além disso, o recrutamento de unidades motoras durante as contrações musculares obedece ao princípio do tamanho, ou seja, o recrutamento de unidades motoras menores, que inervam fibras do tipo I, tem um limiar de ativação mais baixo e são primeiramente recrutadas e, conforme a intensidade da contração muscular aumenta, unidades motoras de maior calibre, que inervam fibras do tipo IIa e IIb, são progressivamente recrutadas (HENNEMANN, 1965). Sendo assim, músculos com constituição mais homogênea possuem uma maior uniformidade no tamanho de suas unidades motoras em relação aos músculos de constituição mais heterogênea, causando diferentes recrutamentos musculares e, conseqüentemente, diferenças na amplitude eletromiográfica (KUKULKA; CLAMANN, 1981).

Kukulka e Clamann (1981) realizaram um experimento com o objetivo de avaliar a taxa de disparo e o recrutamento de unidades motoras em dois músculos do membro superior com diferente função e composição de fibras musculares durante a produção de força em contrações isométricas voluntárias máximas CVM. Os músculos avaliados foram o bíceps braquial, de constituição mista (34\%-61\% de fibras do tipo I) e, geralmente, envolvido com movimentos mais grosseiros e o adutor do polegar, com constituição predominante por fibras do tipo I (72\%-91\%), envolvido com movimentos mais finos e precisos. Os resultados obtidos por Kukulka e Clamann (1981) sugerem que estes dois músculos são controlados de maneira distinta, pois o recrutamento de unidades motoras no bíceps braquial foi maior entre $0-88 \%$ da CVM enquanto que no adutor do polegar nenhuma unidade motora adicional foi recrutada em valores maiores que $50 \%$ da CVM. As taxas de disparo das unidades motoras do adutor do polegar foram maiores, menos regulares e com intervalo inter-pico menores e mais freqüentes em relação ao bíceps braquial. Os autores concluem que a taxa de disparo de unidades motoras tem um papel mais proeminente na força do adutor do polegar enquanto o recrutamento muscular é mais importante na modulação de força do bíceps braquial. 
De acordo com a relação comprimento-tensão, a capacidade de um músculo em gerar força pode variar com o seu comprimento (DE LUCA, 1997). Além disso, em diferentes ângulos articulares, os músculos sinergistas e antagonistas estão em diferentes comprimentos musculares, variando sua relação comprimento-tensão in vivo, resultando em diferentes taxas de ativação das unidades motoras (RASSIER; MACINTOSH; HERZOG, 1999). Resultados divergentes sobre a ativação de unidades motoras em relação ao comprimento muscular são encontrados na literatura.

Kraspisin e Grabiner (2000) avaliaram a influência do ângulo de flexão do cotovelo e do tipo de contração muscular nos níveis de atividade eletromiográfica de músculos flexores do cotovelo durante contrações isométricas voluntárias máximas e durante contrações isocinéticas. Eletromiografia de superfície dos músculos bíceps braquial e braquiorradial foi coletada usando eletrodos bipolares em dez voluntários. As contrações foram realizadas em um dinamômetro isocinético e os voluntários permaneceram sentados, com $90^{\circ}$ de flexão de braço e antebraço em supinação e com o braço em um suporte que mantivesse o posicionamento e que permitisse a realização do exercício. As contrações isocinéticas concêntricas e excêntricas do antebraço foram realizadas em um arco de movimento de $85^{\circ}$, em uma velocidade de $65 \%$ segundo e com força máxima durante todo o arco de movimento. As contrações isométricas foram realizadas em $15^{\circ}$ e $75^{\circ}$ de flexão do cotovelo, com força isométrica máxima durante 3 segundo de contração. As contrações isocinéticas foram avaliadas em dois arcos de movimentos, denominados primeira metade do arco e segunda metade do arco de movimento e as contrações isométricas foram avaliadas pelo tempo de contração.

Os resultados de Kraspisin e Grabiner (2000) demonstraram que durante contrações isocinéticas concêntricas e excêntricas, a influência do ângulo do cotovelo no nível de atividade eletromiográfica foi músculo dependente. Para o músculo bíceps braquial, a segunda metade do arco de movimento nas contrações concêntricas teve menor atividade em relação a primeira metade do arco de movimento e o músculo braquiorradial não teve alteração significativa entre os resultados dos dois arcos de 
movimento. Para as contrações excêntricas, aconteceu o inverso. Para os dados coletados durante as contrações isométricas, o ângulo articular alterou apenas os valores de atividade eletromiográfica do bíceps braquial, que foi significativamente menor em $15^{\circ}$ de flexão do cotovelo quando comparado a $75^{\circ}$ de flexão do cotovelo. Estes resultados demonstram que o nível de atividade eletromiográfica foi maior em curtos comprimentos musculares para contrações isométricas. Assim sendo, os autores concluem que o ângulo articular e o tipo de contração causam diferentes níveis de atividade eletromiográfica em músculos do cotovelo.

Entretanto, valores eletromiográficos similares em diferentes comprimentos articulares também são encontrados na literatura. Bigland-Ritchie et al. (1992) comparou a relação entre as freqüências de disparo de unidades motoras e o nível de força isométrica produzida em contrações isométricas do músculo tibial anterior em dois comprimentos musculares em 5 voluntários saudáveis através da eletromiografia de superfície. Durante o experimento, os voluntários permaneceram sentados com os pés apoiados no solo, em um ângulo de $90^{\circ}$ de flexão da perna. Para encurtar os dorsiflexores, o voluntário avançou sua coxa para frente, sem tirar os pés do solo, formando um ângulo entre $10^{\circ}-20^{\circ}$ de dorsiflexão do tornozelo. A atividade eletromiográfica foi medida através de três níveis de força muscular, $100 \%, 75 \%$ e 50\% da CIVM. Os resultados de Bigland-Ritchie et al. (1992) demonstraram que, apesar dos valores da freqüência de disparo variar entre os níveis de força produzidos, não houve diferença significativa nas taxas de disparo de unidades motoras entre os níveis de esforços realizados, nem quando o comprimento muscular foi alterado.

Também podemos encontra na literatura resultados que mostram maior atividade eletromiográfica em maiores comprimentos musculares em relação a menores comprimentos musculares. Becker e Awiszus (2001) avaliaram a atividade eletromiográfica do quadríceps femoral durante esforço isométrico máximo ( $100 \%$ da CIVM) em um dinamômetro isocinético em 13 diferentes ângulos de flexão do joelho, variando de $30^{\circ}$ a $90^{\circ}$, com aumento de $5^{\circ}$ em $5^{\circ}$. Os resultados demonstraram que entre $30^{\circ}$ e $75^{\circ}$ de flexão do joelho foram encontrados os maiores valores de 
atividade eletromiográfica, que diminuíram com o declínio do ângulo de flexão do joelho.

Newman e Newham (2003) estudaram a atividade elétrica dos músculos quadríceps e isquiotibiais em 5 voluntários saudáveis durante contrações isométricas voluntárias máximas realizadas em um dinamômetro isocinético e em $10^{\circ}, 30^{\circ}, 50^{\circ}$, $70^{\circ}, 90^{\circ}$ e $110^{\circ}$ de flexão do joelho. O valor da CVM obtido em $90^{\circ}$ de flexão do joelho foi usado como valor de referência durante as contrações feitas nas demais angulações. Cada contração teve 3 segundos de duração e o valor de força foi mantido pelos voluntários através de um feedback visual. Os resultados não demonstraram diferença estatisticamente significativa para os valores eletromiográficos dos músculos estudados nas diferentes angulações propostas, evidenciando que o comprimento muscular não alterou a atividade eletromiográfica sob estas condições experimentais.

O sistema nervoso central possui várias estratégias para alterar a força muscular, que podem ser dependentes do número de unidades motoras existentes no músculo (KUKULKA; CLAMMAN, 1981) e do tipo de contração muscular (DE LUCA, 1997), pois unidades motoras são ativadas diferentemente em contrações isométricas e isotônicas, em conseqüência da diferença que elas causam na sinalização dos fusos musculares em movimentos isotônicos e na diferença na ativação de motoneurônios alfa e gama (TAX et al. 1990). Além disso, a força que um músculo é capaz de produzir depende não apenas do comando do sistema nervoso central, mas também do seu comprimento durante a realização de uma tarefa ou movimento e da ativação simultânea de músculos sinergistas para auxiliar na produção do torque (KENNEDY; CRESSWELL, 2001).

Dessa forma, a associação entre diferentes comprimentos musculares e nível de esforço ou a carga empregada para realizar uma tarefa ou um movimento podem causar alterações no recrutamento e nas taxas de disparo de unidades motoras (PASQUET; CARPENTIER; DUCHATEAU, 2005). Tem sido hipotetizado que maiores taxas de disparo de unidades motoras seriam necessárias para produzir um determinado torque em pequenos comprimentos musculares (PASQUET; CARPENTIER; 
DUCHATEAU, 2005). Em relação a esta hipótese, também encontramos resultados divergentes na literatura.

Van der Linden, Kukulka e Soderberg (1991) avaliaram, através de eletromiografia intramuscular, a influência do comprimento muscular no comportamento das unidades motoras do músculo tibial anterior em contrações isométricas de dorsiflexão do tornozelo em 20 voluntários saudáveis. Um equipamento foi confeccionado para manter o voluntário na posição de teste, ou seja, em posição prona, com $90^{\circ}$ de flexão do joelho. Este equipamento permitia ajuste da angulação do tornozelo em $20^{\circ}$ de dorsiflexão, posição neutra $\left(90^{\circ}\right)$ ou em $30^{\circ}$ de flexão plantar para possibilitar a alteração do comprimento muscular. A atividade eletromiográfica foi registrada em uma contração isométrica de rampa, com valores entre $10 \%$ e $40 \%$ da CVM previamente obtida e com aumento progressivo do torque em $5 \%$ do valor da CVM por segundo $(5 \% \mathrm{CVM} / \mathrm{s})$. A contração de rampa foi realizada para as três angulações do tornozelo e teve duração média de oito segundos. A força gerada durante cada contração foi registrada por uma célula de carga, com registro de carga simultâneo ao sinal eletromiográfico. Os resultados demonstraram que a taxa de disparo e o recrutamento de unidades motoras foi maior em curtos comprimentos musculares quando comparados a longos comprimentos musculares em contrações isométricas submáximas.

Entretanto, Bigland-Richie et al. (1992), como descrito anteriormente, não encontraram alterações nas taxas de disparo e no recrutamento de unidades motoras no músculo tibial anterior durante contrações isométricas feitas em dois comprimentos musculares e em 50\%, 75\% e 100\% dos valores de CVM obtidos previamente, demonstrando que diferentes comprimentos musculares não influenciaram as taxas de disparo e de recrutamento de unidades motoras em contrações máximas e submáximas.

Alterações no comprimento muscular, no tipo de contração e na velocidade angular podem causar variações na amplitude do sinal eletromiográfico e, conseqüentemente, na relação EMG-força (DE LUCA, 1997; SUTER; HERZOG, 2000). 
Tax et al. (1990) compararam o comportamento de unidades motoras do músculo bíceps braquial de cinco voluntários durante quatro diferentes tarefas com o objetivo de investigar a diferença na ativação de unidades motoras em movimentos voluntários e em contrações isométricas. Para realizar a comparação entre a atividade das unidades motoras durante as diferentes tarefas, foi realizada eletromiografia intramuscular das cabeças longa e curta do músculo bíceps braquial. Para isso, o protocolo experimental constou de quatro diferentes tarefas comparadas entre si, sendo elas uma isométrica, um movimento voluntário com carga constante, um movimento voluntário com aumento progressivo de carga e um movimento imposto. A tarefa isométrica foi realizada em $80^{\circ}$ de abdução do braço e em $100^{\circ}$ de flexão do antebraço e foi pedido aos voluntários que realizassem um esforço de flexão do antebraço em $20 \%$ do valor da CVM. Os movimentos voluntários foram realizados em um arco de movimento de $20^{\circ}$ e velocidade constante de $3 \%$ segundo, tanto no sentido da flexão $\left(110^{\circ} / 90^{\circ}\right)$ quanto da extensão $\left(90^{\circ} / 110^{\circ}\right)$ do antebraço. Os movimentos voluntários com carga constante tiveram uma carga de $0.15 \mathrm{Nm}$ durante todo o movimento e, nos movimentos voluntários com aumento progressivo de carga, o aumento de carga foi constante e progressivo, de maneira que os voluntários tivessem que aumentar o seu torque flexor ou extensor. O movimento impostou consistiu de um movimento de flexão de cotovelo, realizado um torque flexor que variou a carga de $0 \mathrm{Nm}$ a $20 \%$ da CVM, com velocidade constante de $3 \%$ segundo.

Os resultados de Tax et al. (1990) demonstraram que o pico de recrutamento de unidades motoras foi significativamente menor durante os movimentos isotônicos de flexão e extensão quando comparados com os isométricos e a taxa de disparo inicial de unidades motoras durante o movimento de flexão foi maior e durante a extensão menor quando comparados à contração isométrica. Entretanto, o pico de recrutamento e a taxa inicial de disparo de unidades motoras das contrações isotônicas e isométricas não diferiram dos valores de recrutamento dos movimentos impostos. Através destes resultados, os autores concluem que os motoneurônios são 
diferentemente ativados pelo sistema nervoso central nos movimentos impostos ou em tarefas isométricas quando comparados a movimentos de baixa velocidade.

Babault et al. (2003) estudaram o efeito do comprimento muscular na atividade eletromiográfica e no torque do músculo quadríceps femoral em 9 voluntários durante contrações isométricas e concêntricas realizadas em um dinamômetro isocinético. Durante a análise da atividade eletromiográfica obtida na contração concêntrica, duas velocidades angulares foram analisadas, sendo elas $30 \%$ s e $120 \%$ s. Para avaliar o efeito do comprimento muscular na atividade eletromiográfica tanto das contrações concêntricas quanto das isométricas, as angulações de $35^{\circ}, 55^{\circ}$ e $75^{\circ}$ de flexão do joelho foram analisadas, correspondendo, respectivamente, aos comprimentos musculares encurtado, intermediário e alongado. Os resultados demonstraram que a atividade eletromiográfica foi dependente do comprimento muscular, pois durante as contrações isométricas a atividade eletromiográfica foi maior em curtos comprimentos musculares em relação aos demais, nas contrações concêntricas feitas a $120 \%$ s, a atividade eletromiográfica foi menor no comprimento encurtado em relação aos demais e para as contrações concêntricas em $30 \%$, o comprimento muscular não influenciou a atividade eletromiográfica. $O$ torque produzido não foi significativamente diferente quando comparado entre as contrações concêntricas nas duas velocidades angulares, porém, foi maior nas contrações isométricas quando comparado às concêntricas nas duas velocidades angulares. Os autores concluem que mecanismos periféricos e mudanças no disparo de motoneurônios podem explicar parte das alterações observadas em relação ao comprimento muscular. Também concluíram que a atividade eletromiográfica pode ser influenciada pela velocidade de movimento articular.

Entretanto, o estudo de Nourbakhsh e Kukulka (2004) demonstrou que o efeito das mudanças no torque do músculo tríceps sural foi mais significativo que as variações em seu comprimento muscular na determinação dos níveis de atividade eletromiográfica. Nourbakhsh e Kukulka (2004) avaliaram a atividade eletromiográfica do músculo tríceps sural em diferentes angulações do joelho e do tornozelo em dez 
voluntários saudáveis com o objetivo de avaliar a influência do comprimento muscular e do braço de momento na força e na atividade eletromiográfica do tríceps sural. Dessa forma, diferentes angulações joelho-tornozelo permitiram a análise do tríceps sural em diferentes configurações de comprimento e braço de momento, sendo elas em comprimento e braço de momento curto, em braço de momento curto e comprimento muscular inalterado e comprimento muscular longo e braço de momento inalterado. Os voluntários realizaram flexão plantar em contrações isométricas realizada em um suporte confeccionado para o experimento, que permitia ajustes nas angulações do joelho e tornozelo. O experimento foi realizado nas diferentes configurações joelho-tornozelo e em 10\%, 20\% e 30\% da CVM obtida previamente, para determinar a influência do comprimento muscular e do nível de força na atividade eletromiográfica.

Os resultados de Nourbakhsh e Kukulka (2004) demonstraram um significativo aumento na atividade eletromiográfica do tríceps sural em comprimentos musculares e braço de momento curto e um aumento similar foi encontrado quando o comprimento muscular estava inalterado e o braço de momento curto, porém, não houve alterações significativas em comprimentos musculares curtos e braço de momento inalterado. Dessa forma, os autores concluíram que a alteração do braço de momento foi predominante em relação a alteração do comprimento muscular na determinação dos níveis de atividade eletromiográfica do músculo tríceps sural em torque de flexão plantar isométrico em valores submáximos.

Dessa forma, podemos observar que a constituição de fibras musculares (KUKULKA; CLAMMAN, 1981), a relação comprimento-tensão (DE LUCA, 1997; KRASPISIN; GRABINER, 2000; BECKER; AWISZUS, 2001; NEWMAN; NEWHAM; 2003), a velocidade de contração muscular (TAX et al., 1990; BABAULT et al., 2003), o tipo de contração muscular (TAX et al., 1990; BABAULT et al., 2003), o torque realizado (NOURBAKHSH; KUKULKA, 2004), a colocação de eletrodos (DE LUCA, 1997; FARINA, MERLETTI; ENOKA, 2004), o procedimento de normalização e o tipo de processamento utilizado durante a aquisição e a análise dos dados (FARINA; MERLETTI; ENOKA, 
2004) são fatores que podem influenciar a relação EMG-força. Por fim, esta breve revisão enfatiza a necessidade de padronização do experimento para que fatores que possam ser controlados não interfiram na amplitude do sinal eletromiográfico, possibilitando uma melhor correlação entre EMG-força e facilitando comparação entre estudos.

\subsection{Estudos eletromiográficos sobre os exercícios push-up, bench-press e wall-press}

A eletromiografia é bastante empregada em pesquisas científicas como ferramenta clínica para análise da atividade muscular em indivíduos saudáveis (MOSELEY et al., 1992; UHL et al., 2003) e em indivíduos com alguma disfunção (LUDEWIG et al., 2003). Foram considerados relevantes para esta revisão bibliográfica os estudos que avaliaram a atividade eletromiográfica em exercícios que possam ser empregados em programas de reabilitação, entre eles os utilizados nesta pesquisa, visto que uma possível análise do quanto um determinado exercício ativa um músculo ou um grupo muscular pode tornar mais clara a sua inclusão em um programa de reabilitação (MOSELEY et al., 1992; UHL et al., 2003).

Moseley et al. (1992) analisaram a atividade eletromiográfica dos músculos rombóides, o elevador da escápula, o peitoral menor, as porções superior, média e inferior do trapézio e as porções média e inferior do serrátil em 16 exercícios empregados em protocolos de reabilitação do ombro utilizados pela Clínica Ortopédica Kerlan-Jobe e pelos times de baseball Califórnia Angels e Los Angeles Dodgers, com o objetivo de determinar quais músculos estão mais ativos em cada exercício. A carga empregada em cada exercício foi determinada individualmente e todos os exercícios foram realizados de forma dinâmica, sendo analisadas tanto a fase concêntrica quanto a excêntrica do movimento. A atividade eletromiográfica foi expressa em porcentagem da atividade eletromiográfica adquirida durante o teste de função muscular. 
Para determinar a ativação muscular nos exercícios avaliados, Moseley et al. (1992) utilizaram um critério que compreende tanto valores de intensidade, determinado pelo valor normalizado, quanto pelo número de vezes que esses valores se repetiam nos arcos de movimento avaliados. Um exercício foi considerado ótimo para o fortalecimento de um determinado músculo quando ele gerava uma atividade eletromiográfica de pelo menos $40 \%-50 \%$ do valor de referência em pelo menos 3 arcos de movimento analisados.

Os resultados obtidos por Moseley et al. (1992) demonstram que 12 dos 16 exercícios avaliados foram considerados bons por gerarem valores eletromiográficos considerados ótimos em pelo menos um dos músculos avaliados. Estes autores sugerem que uma combinação dos exercícios de remo, push-up plus (protração da escápula), elevação no plano da escápula e o press-up deveria ser empregada na prática clínica, pois esses exercícios em conjunto foram capazes de ativar todos os músculos estudados em valores considerados ótimos.

Decker et al. (1999) recomendam que exercícios de reabilitação para o ombro durante estágios iniciais de reabilitação devam enfatizar movimentos feitos em baixas amplitudes, evitando tensionar excessivamente os músculos do manguito rotador e os ligamentos do ombro. Em decorrência disto, resolveram estudar a atividade eletromiográfica do músculo serrátil anterior, das porções superior e média do músculo trapézio e das porções anterior e posterior do músculo deltóide e a força de resistência alcançada pelo voluntário em exercícios realizados em uma amplitude de movimento abaixo de $90^{\circ}$ de elevação umeral.

Os exercícios avaliados por Decker et al. (1999) foram a extensão do ombro, o forward punch (movimento de empurrar os braços para frente), serratus anterior punch (protração e retração escapular em flexão de ombro e extensão de cotovelo), dynamic hug (flexão horizontal do braço com extensão de cotovelo), abdução no plano da escápula com rotação externa, push-up, push-up plus (realizado com protração escapular) e knee push-up (push-up com apoio nos joelhos). A atividade eletromiográfica dos músculos avaliados foi captada durante a realização dinâmica 
destes exercícios e os valores de amplitude eletromiográfica analisados correspondem a uma média dos valores obtidos durante todo o movimento.

Os dados eletromiográficos obtidos por Decker et al. (1999) foram normalizados como no estudo de Moseley et al. (1992). Para um exercício ser considerado clinicamente relevante, ele deveria ativar os músculos em porcentagens maiores que $20 \%$ da CIVM. Porcentagens de $0 \%-20 \%$ foram consideradas mínimas, de $21 \%-50 \%$ moderadas e acima de $50 \%$ máximas. Seus resultados demonstraram que os exercícios serratus anterior punch, elevação no plano da escápula, dynamic hug, push-up plus e o knee push-up plus ativaram o músculo serrátil anterior em porcentagens além das consideradas mínimas, sendo moderada a atividade alcançada no push-up plus e a máxima no dynamic hug. As fibras superiores do músculo trapézio foram mais ativadas durante os exercícios de elevação da escápula e dynamic hug enquanto as fibras médias tiveram sua maior atividade eletromiográfica durante o exercício de elevação da escápula. As fibras anteriores do músculo deltóide tiveram valores eletromiográficos maiores que $20 \%$ durante os exercícios serratus anterior punch, elevação no plano da escápula, dynamic hug, push-up plus, knee push-up plus, press-up e forward punch enquanto as fibras posteriores foram mais ativadas durante a elevação no plano da escápula e na extensão do ombro.

Em relação ao push-up plus e suas variações, os estudos de Moseley et al. (1992) e Decker et al. (1999) obtiveram como resultado comum uma maior ativação do músculo serrátil anterior, justificada pelo movimento de protração e retração escapular. Além disso, durante o exercício push-up, Moseley et al. (1992) encontraram uma ativação significativa para o músculo peitoral maior, relacionada com o movimento de protração escapular, enquanto Decker et al. (1999) encontraram resultados significativos para o deltóide anterior, justificada pelos autores como decorrente da relação entre este músculo com os músculos rotadores da escápula durante o movimento de elevação do braço.

Dillman, Murray e Hintermeister (1994) realizaram um estudo de caso que avaliou a atividade eletromiográfica dos músculos peitoral maior, infra-espinhoso, 
subescapular e das porções anterior, média e posterior do músculo deltóide em 10 exercícios compreendidos na classificação proposta pelos autores, entre eles o benchpress, o push-up e o wall-press. Este artigo propôs uma nova classificação para exercícios da extremidade superior, como explicado no item anterior desta revisão bibliográfica, e teve por objetivo testar a hipótese proposta pelos autores de que se a direção e a quantidade de carga nos exercícios classificados em EFC, EMC ou EMSC forem similares, a atividade eletromiográfica dos músculos motores primários também seria comparável, independente da condição da extremidade.

Os exercícios considerados como EFC foram o wall-press (apoio das duas mãos), o axial wall-press (apoio de uma mão), knee push-up, o push-up e o push-up plus. Os considerados EMC foram a extensão do braço o bench-press e o exercício considerado EMSC foi o bench-press sem carga. Os exercícios foram realizados isotonicamente e tanto a fase de força, considerada a porção do movimento em que o voluntário aumentava a distância entre o segmento distal e o corpo quanto a fase de absorção, em que o voluntário aproximava o segmento distal do corpo foram analisadas através de uma média da amplitude eletromiográfica de cada fase, expressa como porcentagem da CIVM.

Os resultados obtidos por Dillman, Murray e Hintermeister (1994) indicaram que os exercícios das condições EFC e EMC tiveram atividade eletromiográfica comparável, como hipotetizado pelos autores, justificada pela similaridade biomecânica entre eles (direção e magnitude de carga).

Blackard, Jensen e Ebben (1999) fizeram um estudo similar ao de Dillman, Murray e Hintermeister (1994). Para realizar o estudo, os pesquisadores analisaram a atividade eletromiográfica do músculo peitoral maior e da cabeça longa do músculo tríceps braquial em 10 voluntários saudáveis em 3 exercícios considerados pelos autores como biomecanicamente comparáveis. Os exercícios analisados foram o pushup, o bench-press com carga e o bench-press sem carga, que equivaleriam a exercícios de cadeia cinética fechada/extremidade fixa com carga, extremidade móvel com carga e cadeia cinética aberta/extremidade móvel sem carga, respectivamente. 
Os exercícios foram realizados em isotonia e, assim como no estudo de Dillman, Murray e Hintermeister (1994), a atividade eletromiográfica das fases de força e de absorção dos exercícios foi analisada. Os resultados obtidos por Blackard, Jensen e Ebben (1999) concordam com os de Dillman, Murray e Hintermeister (1994), pois exercícios considerados com carga e biomecânica similares tiveram valores eletromiográficos comparáveis entre músculos motores primários.

Entretanto, Blackard, Jensen e Ebben (1999) observaram uma diferença estatisticamente significativa entre os exercícios bench-press com carga e o benchpress sem carga, qualificados como exercícios com mesma condição de extremidade e diferente carga e entre os exercícios push-up e bench-press sem carga, exercícios realizados com diferente carga e condição de extremidade. De acordo com esses resultados, os autores concluem que a quantidade de carga empregada durante a realização de um exercício pode ser mais importante que a condição da extremidade durante a análise eletromiográfica da musculatura envolvida.

O estudo de Barnett, Kippers e Turner (1995) avaliou os efeitos da inclinação do tronco e da largura da pegada (distância entre as mãos) na atividade eletromiográfica das porções esternocostal e clavicular do peitoral maior, fibras anteriores do músculo deltóide, cabeça longa do músculo tríceps braquial e músculo grande dorsal em 4 variações do exercício bench-press em seis voluntários do sexo masculino, com pelo menos 1 ano de experiência em levantamento de peso. As variações do bench-press foram o flat bench-press (tronco na horizontal), o benchpress inclinado (tronco a $40^{\circ}$ acima da linha horizontal), o bench-press declinado (tronco a $18^{\circ}$ abaixo da linha horizontal) e o vertical bench-press (tronco na vertical), todos realizados em duas larguras de pegada, sendo uma delas na medida da distância biacromial (100\% da DBA) e outra com o dobro da distância biacromial (200\% da DBA). A determinação da carga máxima levantada durante os exercícios foi realizada uma semana antes. Os exercícios foram realizados de maneira dinâmica, iniciados na posição de extensão do braço e flexão de cotovelo, com a barra próxima 
ao peito e concluído com a flexão de braço e extensão do cotovelo, com a barra afastada do peito.

Os resultados obtidos por Barnett, Kippers e Turner (1995) demonstraram que a porção esternocostal do peitoral maior teve uma menor atividade eletromiográfica no vertical bench-press quando comparado com os demais, independentemente da largura da pegada. Em relação à pegada de $200 \%$ da DBA, a atividade deste músculo foi maior no bench-press horizontal e com $100 \%$ da DBA, a posição inclinada gerou menor atividade eletromiográfica. Os dados eletromiográficos da porção anterior do músculo deltóide mostram que a $200 \%$ da DBA, foram observadas os maiores valores para as posições vertical e inclinada quando comparados com as posições horizontal e declinada. Em relação ao músculo tríceps braquial, os dados eletromiográficos foram menores nas posições inclinada e vertical quando comparados com a posição horizontal e a distância de $100 \%$ da DBA exibiu maior atividade eletromiográfica que a pegada com $200 \%$ da DBA. O grande dorsal foi o músculo que teve menor ativação em todos os exercícios, porém, independente da largura da pegada, a posição declinada ativou mais este músculo que a posição inclinada.

Lear e Gross (1998) estudaram a atividade eletromiográfica das fibras superiores e inferiores do músculo trapézio e do músculo serrátil anterior em uma progressão do exercício push-up plus (push-up com protração escapular), escolhido pelos autores por ser um exercício bastante empregado em protocolos de reabilitação da extremidade superior, com o propósito de treinamento avançado da musculatura estabilizadora da escápula. O objetivo deste estudo foi avaliar a atividade eletromiográficas dos estabilizadores escapulares e determinar o quanto o grau de dificuldade do exercício alteraria estes valores.

O exercício push-up plus estudado por Lear e Gross (1998) teve 3 níveis progressivos de dificuldade, denominados condição 1,2 e 3 . A condição 1 constitui o push-up plus padrão, com apoio das mãos e pés no solo; na condição 2, o exercício foi realizado com os pés elevados a $45,7 \mathrm{~cm}$ do solo, enquanto as mãos permaneceram sobre o solo e na condição 3, o push-up plus foi feito com as mãos posicionadas sobre 
um mini trampolim a $17.8 \mathrm{~cm}$ do solo e com os pés sobre o assento de uma cadeira em uma altura de $63.5 \mathrm{~cm}$ do solo.

Seus resultados evidenciaram que durante a progressão do exercício houve um aumentou a atividade eletromiográfica do músculo serrátil anterior e das fibras superiores do músculo trapézio. A ativação do músculo serrátil anterior foi maior nas condições 2 e 3 quando comparadas com a condição 1, porém, não houve diferença estatisticamente significativa entre as condições 2 e 3. Em relação às fibras superiores do músculo trapézio, a atividade eletromiográfica também foi maior nas condições 2 e 3 quando comparadas com a condição 1 , não havendo diferença estatisticamente significativa entre as condições 2 e 3. Lear e Gross (1998) sugerem o uso da progressão do exercício push-up proposta em seu estudo durante a reabilitação clínica quando se pretende aumentar a ativação do músculo serrátil anterior e das fibras superiores do músculo trapézio, visto que o grau de dificuldade aumentou a atividade eletromiográfica dos músculos avaliados. Entretanto, os autores comentaram que nem todas as pessoas têm habilidade para fazer esses exercícios em decorrência da dificuldade em manter o posicionamento.

Uhl et al. (2003) analisaram a atividade eletromiográfica das porções anterior e posterior do músculo deltóide, do peitoral maior e do infraespinhoso em 18 voluntários saudáveis com o propósito de analisar se existe relação entre o aumento da sustentação de peso na extremidade superior com a atividade eletromiográfica da musculatura ao redor do ombro. Para avaliar as possíveis alterações eletromiográficas, sete exercícios de sustentação de peso foram analisados, sendo que o aumento da descarga de peso sobre a extremidade superior era causado por variações da postura do indivíduo durante a realização do exercício.

Os exercícios realizados são semelhantes ao push-up padrão e foram selecionados por causar diferentes cargas sobre a extremidade superior, que aumentaram de acordo com a retirada de um membro superior, ou com a retirada de um membro inferior ou com a retirada simultânea de um membro superior e um inferior do solo. Os exercícios avaliados foram o prayer, quadruped, tripod, pointer, 
push-up, push-up com pés elevados e o one arm push-up, sendo que essa seqüência mostra o aumento progressivo da descarga de peso sobre a extremidade superior. Entre os exercícios estudados, o que mais se assemelha a esta pesquisa é o tripod position (push-up realizado com apoio em um braço e com o indivíduo ajoelhado).

Foram feitas três repetições isométricas de cada exercício, com duração de cinco segundos cada. A atividade muscular foi determinada em porcentagens do valor obtido para cada músculo durante o teste de função muscular e foram classificadas em quatro categorias, sendo considerada mínima abaixo de $20 \%$, moderada de $20 \%$ $40 \%$, alta de $41 \%-60 \%$ e muito alta maior que $60 \%$. Os resultados eletromiográficos obtidos demonstraram que o músculo infraespinhoso teve maior atividade eletromiográfica em relação aos demais músculos na maioria dos exercícios analisados e que a atividade eletromiográfica da maioria dos músculos avaliados foi maior no exercício one arm push-up em relação aos demais exercícios.

Para determinar a correlação entre a descarga de peso corporal e a atividade eletromiográfica, os dados foram analisados através da Correlação de Pearson. Os resultados evidenciaram uma alta correlação entre o aumento de descarga de peso corporal com a atividade muscular, demonstrando que alterações no posicionamento do braço e, consequentemente na quantidade de carga, alteraram a demanda da atividade eletromiográfica na musculatura avaliada.

Os resultados de Uhl et al. (2003) evidenciam que o aumento da descarga de peso sobre a extremidade superior aumentou a atividade muscular. Entretanto, os autores disseram que não analisaram os efeitos que as forças de cisalhamento e de compressão axial teriam sobre a musculatura de pacientes com disfunções do complexo articular do ombro, considerando importante analisar a atividade eletromiográfica em pacientes, para que comparações possam ser feitas.

A atividade eletromiográfica do músculo serrátil anterior e das fibras superiores do músculo trapézio, através do quociente TS/SA (atividade eletromiográfica das fibras superiores do músculo trapézio pela atividade eletromiográfica do músculo serrátil anterior) foi analisada por Ludewig et al. (2004) em variações do exercício 
push-up com o objetivo de analisar qual variação deste exercício push-up padrão ativaria mais o músculo serrátil anterior e menos as fibras superiores do músculo trapézio. A pesquisa teve como amostra dois grupos de 30 indivíduos, sendo um deles formado por indivíduos considerados saudáveis e o outro formado por indivíduos com algum tipo de dor ou disfunção no ombro.

Os autores justificam a importância do estudo deste quociente pelo fato de que doenças do complexo articular do ombro e movimentos anormais da escápula podem estar relacionadas mais ao desequilíbrio da atividade muscular do que a fraqueza dos músculos escapulotorácicos. Estes autores dizem que um desequilíbrio entre os músculos serrátil anterior e fibras superiores do trapézio podem levar a condições clínicas como síndrome do impacto, tendinites e alterações biomecânicas. Dessa forma, exercícios que ativam mais o serrátil anterior e menos as fibras superiores do trapézio são importantes em protocolos de tratamento para o controle escapular.

Os exercícios estudados por Ludewig et al. (2004) foram o push-up padrão, o knee push-up plus (push-up com protração escapular e com apoio nos joelhos e mão), o elbow push-up plus (push-up com protração escapular e com apoio no antebraço e pés) e o wall push-up plus (indivíduo em pé, com as mãos apoiadas na parede). Os exercícios foram realizados dinamicamente e a análise eletromiográfica foi realizada nas fases concêntrica e excêntrica do arco de movimento. Os autores realizaram o cálculo do quociente entre a porção superior do músculo trapézio pelo músculo serrátil anterior (quociente TS/SA) através da razão entre o valor de RMS normalizado das fibras superiores do músculo trapézio pelo valor de RMS normalizado das fibras anteriores do músculo serrátil. Os valores de TS/SA foram considerados baixos quando menores que 0,3 e valores próximos ou maiores que 1,0 foram considerados elevados.

Os resultados indicaram similaridade entre os grupos durante as condições avaliadas. O menor valor de TS/SA foi encontrando durante o push-up plus, sugerindo este exercício como o mais indicado quando se deseja fortalecer o serrátil anterior. Porém se a pretensão clínica for obter uma atividade mais equilibrada entre os dois músculos, os autores sugerem o uso do knee puh-up plus, do elbow push-up plus e do 
wall push-up plus, pois estes exercícios demonstraram valores maiores para o quociente TS/SA, sendo que o maior valor encontrado durante o wall push-up plus.

O exercício push-up e suas variações foram estudados por Gouvali e Bodoulos (2005). Estes autores avaliaram a atividade eletromiográfica dos músculos tríceps braquial e porção clavicular do peitoral maior e a força de reação em valores referentes a porcentagem do peso corporal em 8 homens saudáveis durante 6 variações do exercício push-up, sendo elas o push-up padrão o knee push-up, o pushup padrão com os braços abduzidos em $150 \%$ da medida da largura entre os ombros, o push-up padrão com os braços aduzidos em $50 \%$ da medida da largura entre os ombros, o push-up padrão com os braços anteriorizados em $30 \%$ da medida da largura entre ombros e o push-up padrão com os braços posteriorizados em $30 \%$ da medida da largura entre ombros.

Os voluntários realizaram os exercícios em uma série de cinco repetições, sem controle de velocidade e de maneira dinâmica, compreendendo uma fase de flexão, que permitia a aproximação do tórax ao solo e uma fase de extensão, que afastava o tórax do solo. Os valores de força de reação foram registrados através de uma plataforma de força, sendo a descarga de peso obtida no exercício push-up padrão o valor de referência utilizado para zerar a plataforma de força antes do início de cada exercício. Este equipamento serviu como referência para a descarga de peso corporal obtida durante a realização de cada exercício e o registro da força foi simultâneo ao registro do sinal eletromiográfico.

Os resultados demonstraram que houve uma atividade eletromiográfica significativamente maior da cabeça longa do músculo tríceps braquial e uma atividade eletromiográfica significativamente menor do músculo peitoral maior durante a comparação do push-up com os braços posteriorizados com o push-up padrão. 0 exercício knee push-up foi que obteve os menores valores eletromiográficos para os músculos avaliados. Não houve diferença estatisticamente significativa entre os demais exercícios. Em relação à força de reação vertical, os resultados demonstraram 
que o maior valor obtido na plataforma de força foi no exercício push-up padrão e o valor mínimo no push-up com os braços anteriorizados.

Gouvali e Bodoulos (2005) concluem que existe diferença na força e na atividade eletromiográfica em diferentes posições do exercício push-up padrão, sugerindo que os clínicos podem alterar a carga imposta ao segmento e o recrutamento muscular através do posicionamento do braço.

A pesquisa de Cogley et al. (2005) também avaliou as possíveis alterações da atividade eletromiográfica dos músculos peitoral maior e tríceps braquial em 40 voluntários, sendo 11 homens e 29 mulheres durante a realização de diferentes posições do exercício push-up padrão. As posições estudadas foram o push-up padrão feito com as mãos na largura dos ombros; o push-up com base larga, realizado com as mãos a uma distância de $20 \mathrm{~cm}$ lateral ao ombro e o push-up com base estreita, realizado com as mãos unidas na altura do osso esterno. Os exercícios foram realizados de maneira dinâmica e o registro da atividade eletromiográfica durou 3 segundos, com o início na posição em que os antebraços estão fletidos e o tórax próximo ao chão e com término com os antebraços estendidos e o tórax afastado do solo. A carga não foi mensurada nesta pesquisa e os resultados eletromiográficos foram calculados em porcentagens da atividade eletromiográfica obtida através de uma contração isométrica voluntária máxima realizada em prova de função muscular.

Os resultados demonstram que o push-up com base estreita gerou uma maior atividade eletromiográfica para os músculos peitoral maior e tríceps braquial quando comparado com o exercício push-up com base larga. Entretanto, não houve diferença estatisticamente significativa entre o push-up padrão e o push-up com base estreita. Portanto, os autores sugerem o exercício push-up em base estreita para o fortalecimento dos músculos peitoral maior e tríceps braquial.

Lehman (2005) estudou o exercício bench-press e suas variações em 12 homens saudáveis e com experiência em levantamento de peso há pelo menos 6 meses com o objetivo de avaliar possíveis alterações eletromiográficas causadas pela variação do posicionamento do antebraço e da largura da pegada durante a realização 
do exercício. A análise eletromiográfica foi realizada nos músculos peitoral maior, bíceps e tríceps braquial. A carga foi definida individualmente e o valor considerado foi o máximo valor em que o voluntário conseguisse realizar 12 repetições do exercício. As duas larguras de pegada estabelecidas foram com as mãos afastadas na largura do acrômio (distância biacromial - 100\% DBA) e mãos afastadas em 2 vezes à distância biacromial (200\% DBA) e as posições de antebraço foram a pronação e supinação.

Dessa forma, as posições avaliadas foram antebraço pronado a $100 \%$ da DBA, antebraço pronado a $200 \%$ da DBA, antebraço supinado a $100 \%$ da DBA, antebraço supinado a $100 \%$ da DBA e antebraço pronado com uma mão de distância entre as mãos. Cada voluntário realizou uma repetição do exercício em cada posição, partindo da posição de extensão do ombro e flexão do cotovelo, ou seja, com a barra próxima ao peito e indo para a posição de flexão do ombro e extensão do cotovelo, permanecendo nesta posição durante 5 segundos, para que o registro eletromiográfico pudesse ser captado neste período de contração isométrica.

Os resultados de Lehman (2005) demonstraram que o bench-press realizado com o antebraço supinado aumentou a atividade eletromiográfica da porção clavicular do peitoral maior em relação ao antebraço pronado em todas as distâncias entre as mãos. Entretanto, a porção esternoclavicular do peitoral maior teve sua atividade eletromiográfica diminuída se a distância entre as mãos diminuísse, porém, a supinação do antebraço não causou alterações significativas na atividade eletromiográfica da porção esternoclavicular do peitoral maior.

A atividade eletromiográfica do músculo tríceps braquial aumentou na posição pronada do antebraço durante a posição de menor distância entre as mãos. Já a pegada a $100 \%$ da DBA, causou aumento da atividade do tríceps braquial tanto na posição pronada quanto supinada do antebraço. A posição supinada do antebraço não causou alterações significativas na atividade eletromiográfica deste músculo nas diferentes distâncias estipuladas. O bíceps braquial aumentou sua atividade eletromiográfica durante $\mathrm{o}$ bench-press feito com o antebraço supinado tanto na pegada a $100 \%$ da DBA quanto a $200 \%$ da DBA quando comparada com a posição 
pronada do antebraço nestas duas distâncias de pegada. Os autores concluem que a escolha da distância da pegada não interferiu nos resultados, pois pequenas alterações eletromiográficas foram observadas entre as distâncias estudadas.

Oliveira et al. (2006) avaliou a influência da direção da carga e da condição da extremidade na atividade elétrica de músculos da cintura escapular e membro superior durante a realização de exercícios isométricos com a extremidade distal fixa e carga axial (EFCA) e extremidade livre com carga externa rotacional (ELCR), ou seja, classificados de acordo com a condição da extremidade e direção da carga, em 20 voluntárias saudáveis e destras. Eletromiografia de superfície dos músculos bíceps braquial, tríceps braquial, porção clavicular do músculo peitoral maior, fibras superiores do músculo trapézio e anteriores do músculo deltóide foram registradas durante os exercícios wall-press e bench-press, considerados EFCA e durante a elevação do braço no plano escapular e na extensão do horizontal do braço, considerados EFCR. A carga axial empregada durante os exercícios em EFCA foi a máxima que a voluntária conseguiu realizar e a carga empregada durante os exercícios EFCR foi estabelecida como a carga máxima que a voluntária conseguia levantar sem que houvesse perda da estabilidade na contração, movimento acessório ou incapacidade de elevar a carga. Cada exercício foi realizado três vezes, com intervalo de dois minutos entre as repetições e com quatro segundos de registro eletromiográfico. Os valores de RMS foram normalizados pelo valor médio obtido de três contrações isométricas voluntárias máximas, obtidas previamente em prova de função muscular.

Os resultados obtidos por Oliveira et al. (2006) demonstraram que não houve diferença estatisticamente significativa entre as amplitudes de ativação das fibras anteriores do músculo deltóide e da porção clavicular do peitoral maior quando comparadas ao wall-press e bench-press e entre as amplitudes de ativação do músculo tríceps braquial quando comparados os exercícios de elevação no plano escapular e a extensão horizontal do braço. Os valores de RMS normalizados foram estatisticamente maiores na tarefa bench-press para os músculos tríceps braquial, na 
tarefa de elevação no plano escapular para as fibras anteriores do deltóide, para o bíceps braquial e para as fibras anteriores do trapézio e na tarefa wall-press para a porção clavicular do músculo peitoral.

Na comparação entre as amplitudes eletromiográficas em cada tarefa proposta, os resultados de Oliveira et al. (2006) demonstraram que os valores médios de RMS normalizados das fibras superiores do músculo trapézio foram maiores que o do bíceps braquial, tríceps braquial, porção clavicular do peitoral e fibras anteriores do deltóide durante o wall-press. Na tarefa bench-press, os valores de RMS normalizados do tríceps braquial foram significativamente maiores que os valores de RMS normalizados das fibras superiores do trapézio e da porção clavicular do peitoral; o valor de RMS normalizado das fibras anteriores do deltóide foi significativamente maior que o do músculo trapézio e do bíceps braquial e a atividade da porção clavicular do peitoral foi significativamente maior que a do bíceps braquial. Na elevação do braço no plano escapular, os valores médios de RMS normalizados das fibras superiores do músculo trapézio foram estatisticamente maiores que os dos músculos bíceps braquial, tríceps braquial e da porção clavicular do peitoral maior e as fibras anteriores do músculo deltóide tiveram maiores valores de RMS normalizados que os músculos tríceps braquial, bíceps braquial e porção clavicular do peitoral maior e, na extensão horizontal do braço, as fibras superiores do músculo trapézio apresentaram maior valor de RMS normalizado quando comparadas as dos músculos tríceps braquial, bíceps braquial e porção clavicular do peitoral. Os autores concluíram que exercícios semelhantes classificados pela condição da extremidade e pela direção da carga aplicada ao membro superior promoveram semelhantes níveis de atividade eletromiográfica em apenas parte dos músculos estudados, sugerindo que a análise biomecânica do exercício, em relação a sua condição da extremidade e carga empregada, parece ser mais relevante quando se pretende prever a capacidade do exercício em elicitar algum nível de atividade eletromiográfica.

A pesquisa de Oliveira, Cardoso e De Brum (2006) avaliou a atividade eletromiográfica das fibras superiores do músculo trapézio, da cabeça longa do 
músculo bíceps braquial, das fibras posteriores do músculo deltóide e do músculo serrátil anterior de 14 voluntários durante a realização dos exercícios wall-press nas angulações de $90^{\circ}$ e $45^{\circ}$ da articulação glenoumeral e os exercícios bench-press e push-up em $90^{\circ}$ da articulação glenoumeral. Os exercícios foram realizados em isometria, sobre uma superfície estável e sobre uma superfície instável, proporcionada por uma bola terapêutica. Os voluntários realizaram os exercícios com o maior esforço isométrico possível. Os resultados referentes à superfície estável evidenciaram valores elevados de ativação eletromiográfica das fibras superiores do trapézio em relação aos demais músculos durante o exercício wall-press $90^{\circ}$. Em relação ao exercício push-up e bench-press, os resultados indicaram valores significativos de ativação eletromiográfica para os músculos serrátil anterior e deltóide anterior, justificada pela protração que a carga axial ocasionou na articulação escapulotorácica.

Os resultados da superfície instável demonstraram uma maior atividade eletromiográfica do músculo serrátil anterior em relação aos demais músculos em todos os exercícios avaliados, justificada pela protração escapular causada pela carga axial imposta ao segmento e pela ação estabilizadora na articulação escapulotorácica. No exercício push-up, apesar da atividade eletromiográfica do serrátil anterior ser maior, não houve diferença estatisticamente significativa entre este músculo e o peitoral maior. Oliveira, Carvalho e De Brum (2006) concluíram que a atividade elétrica dos músculos estudados durante exercícios com extremidade fixa e carga axial foi diferente entre as superfícies.e que apenas o exercício bench-press não causou diferenças significativas nos valores de amplitude eletromiográfica para todos os músculos estudados em relação à base de suporte usada. 
"As únicas coisas que se interpõem entre um homem e o que ele quer da vida são freqüentemente a vontade de tentar e a fé para acreditar que é possível"

Richard Devos

\section{Casuística e Métodos}




\section{Casuística e Métodos}

\subsection{Descrição da amostra}

Participaram desta pesquisa 20 voluntários sedentários do sexo masculino, destros e que se enquadraram nos critérios de inclusão e exclusão estabelecidos para a pesquisa, ou seja, que não apresentavam história de trauma na cintura escapular e nos membros superiores, hipotrofia visível e pontos gatilhos nos músculos avaliados e que apresentaram ausência de sinais clínicos de síndrome do impacto, epicondilite lateral ou medial e instabilidade articular do ombro, cotovelo e punho, constatados através de testes ortopédicos específicos. A descrição dos testes ortopédicos encontrase no apêndice $A$.

Dados antropométricos também foram estabelecidos para auxiliar na padronização da amostra. A escolha dos voluntários teve relação com a proximidade desses valores, principalmente com a altura e comprimento dos segmentos (tabela 1).

Tabela 1. Médias e desvios-padrão dos dados antropométricos dos voluntários.

$\begin{array}{lr}\text { Idade }(\mathrm{a}) & 22,8 \pm 3,10 \\ \text { Peso }(\mathrm{Kg}) & 68,7 \pm 7,90 \\ \text { Altura }(\mathrm{m}) & 1,75 \pm 0,05 \\ \text { Comprimento Braço }(\mathrm{cm}) & 32,4 \pm 1,70 \\ \text { Comprimento Antebraço }(\mathrm{cm}) & 22,8 \pm 1,10 \\ \text { Comprimento Mão }(\mathrm{cm}) & 17,8 \pm 0,90\end{array}$

a (ano); Kg (kilograma), m (metro), cm (centímetro).

Foram considerados sedentários os voluntários que realizassem até duas atividades físicas diferentes, repetidas no máximo 3 vezes por semana, não específicas para membros superiores e sem caráter de treinamento físico desportivo. 
Ao aceitarem participar da pesquisa, os voluntários assinaram um termo de consentimento, que se encontra no apêndice B, segundo a resolução n 196/96 do Conselho Nacional da Saúde. O procedimento experimental deste trabalho teve a aprovação do Comitê de Ética da Faculdade de Medicina de Ribeirão Preto da Universidade de São Paulo - USP.

\subsection{Avaliação Física}

A avaliação física compreendeu uma anamnese e um exame físico, durante os quais foram colhidos dados pessoais e antropométricos dos voluntários, abordando questões relacionadas a histórias de traumas e doenças prévias na região da cintura escapular e membros superiores, além de um questionamento sobre as atividades físicas realizadas pelos voluntários. Os voluntários que apresentaram restrição de movimento na articulação do ombro e/ou presença de arco doloroso durante os movimentos de elevação do braço foram excluídos da pesquisa pelo fato desses fatores provocarem variações nos padrões eletromiográficos nos diferentes músculos da cintura escapular e do braço (KELLY et al., 1997). A ficha de avaliação física encontra-se no apêndice C.

\subsection{Materiais Utilizados}

Foram utilizados os seguintes materiais e equipamentos:

- Microcomputador Pentium $4^{1}$;

- Eletromiográfo Myosystem Br-1 (Datahominis Tecnologia ${ }^{\circledR}$ Ltda, Uberlândia, Brasil) ${ }^{1}$;

- Programa Myosystem Br-1 versão 2.9b (Datahominis Tecnologia ${ }^{\circledR}$ Ltda, Uberlândia, Brasil) ${ }^{1}$; 
- Eletrodos de superfície ativos simples diferenciais (EMG System do Brasil, São José dos Campos, Brasil) ${ }^{1}$;

- Eletrodo de Referência de aço inox (BIO-Logic, Campinas, Brasil) ${ }^{1}$;

- Gel condutor;

- Esparadrapo para fixação dos eletrodos;

- Algodão, álcool 92\% e lâmina de barbear para limpeza do local de colocação dos eletrodos;

- Maca e suportes para a realização dos exercícios;

- Célula de Carga MM (Kratos Dinamômetros Ltda, Brasil) ${ }^{1}$;

- Condicionador de Sinais para célula de carga C500 DataHominis (Datahominis ${ }^{\circledR}$ Tecnologia Ltda, Uberlândia, Brasil);

- Balança Antropométrica;

- Ficha de Avaliação Fisioterapêutica;

- Goniômetro Universal (Carci, São Paulo, Brasil);

- Fita Métrica

\subsection{Equipamento}

\subsubsection{Eletromiógrafo e Programa}

Foram utilizados sete canais para eletromiograma e um canal auxiliar do equipamento Myosystem $\mathrm{Br}-1$ (DataHominis Tecnologia ${ }^{\circledR}$ Ltda, Uberlândia, Brasil) para a aquisição dos registros eletromiográficos e da força produzida pelo voluntário, respectivamente (Figura 1). O equipamento possui aterramento e aquisição simultânea comum para os canais, filtros de baixa passagem de $10 \mathrm{~Hz}$ a $1,5 \mathrm{KHz}$, três estágios de

\footnotetext{
${ }^{1}$ Equipamento comprado com Auxílio à Pesquisa Fapesp (Processo no 2003/13042-1)
} 
amplificação, impedância de canais de $10 \mathrm{G} \Omega$ em modo diferencial e placa conversora analógica-digital com 12 bits de faixa de resolução dinâmica, faixa de amplitude de $10 \mathrm{~V}$

a +10V, freqüência de amostragem por canal de $4 \mathrm{KHz}$ e Razão de Rejeição de Modo Comum de $130 \mathrm{~dB}$. O canal auxiliar foi utilizado para aquisição simultânea e sincronizada dos valores de força registrados por uma célula de carga. Para visualização e processamento dos sinais eletromiográficos e de força foi utilizado o programa Myosystem $\mathrm{Br}-1$ versão $2.9 \mathrm{~b}$ (Figuras 2 e 3).

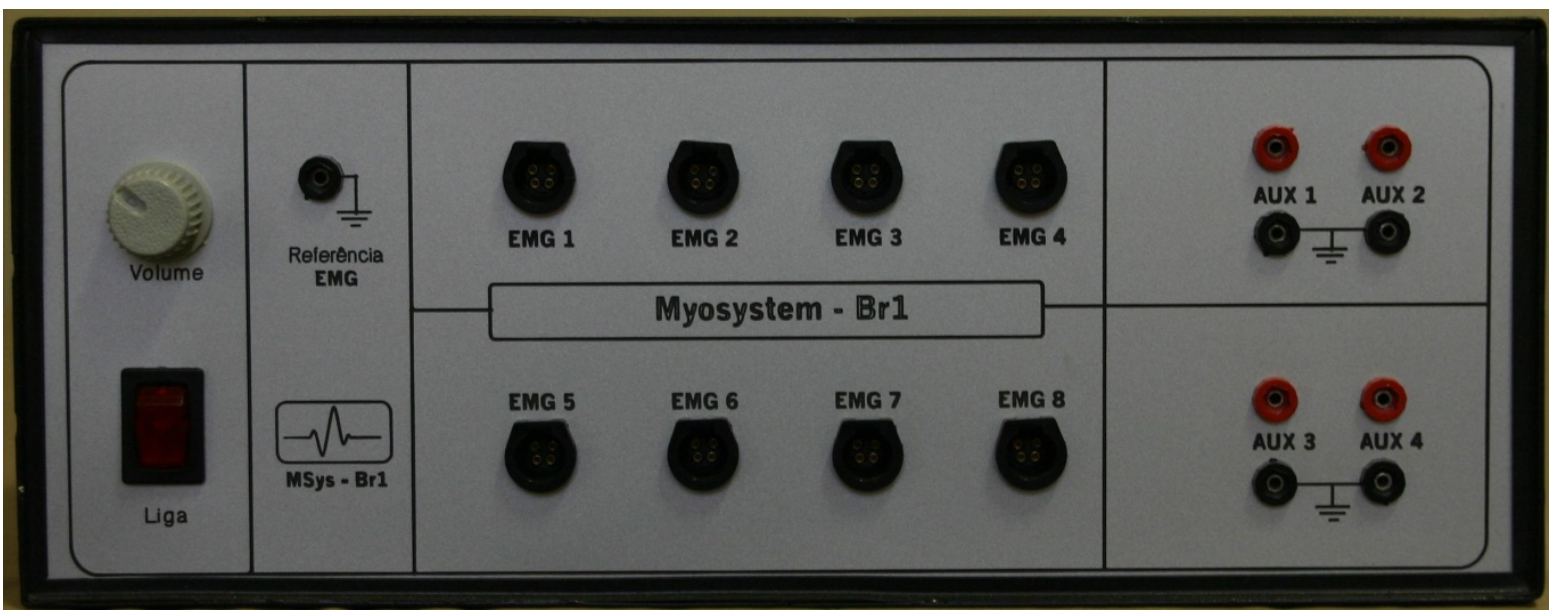

Figura 1. Equipamento Myosystem $\mathrm{Br}-1$ - Vista Anterior. 


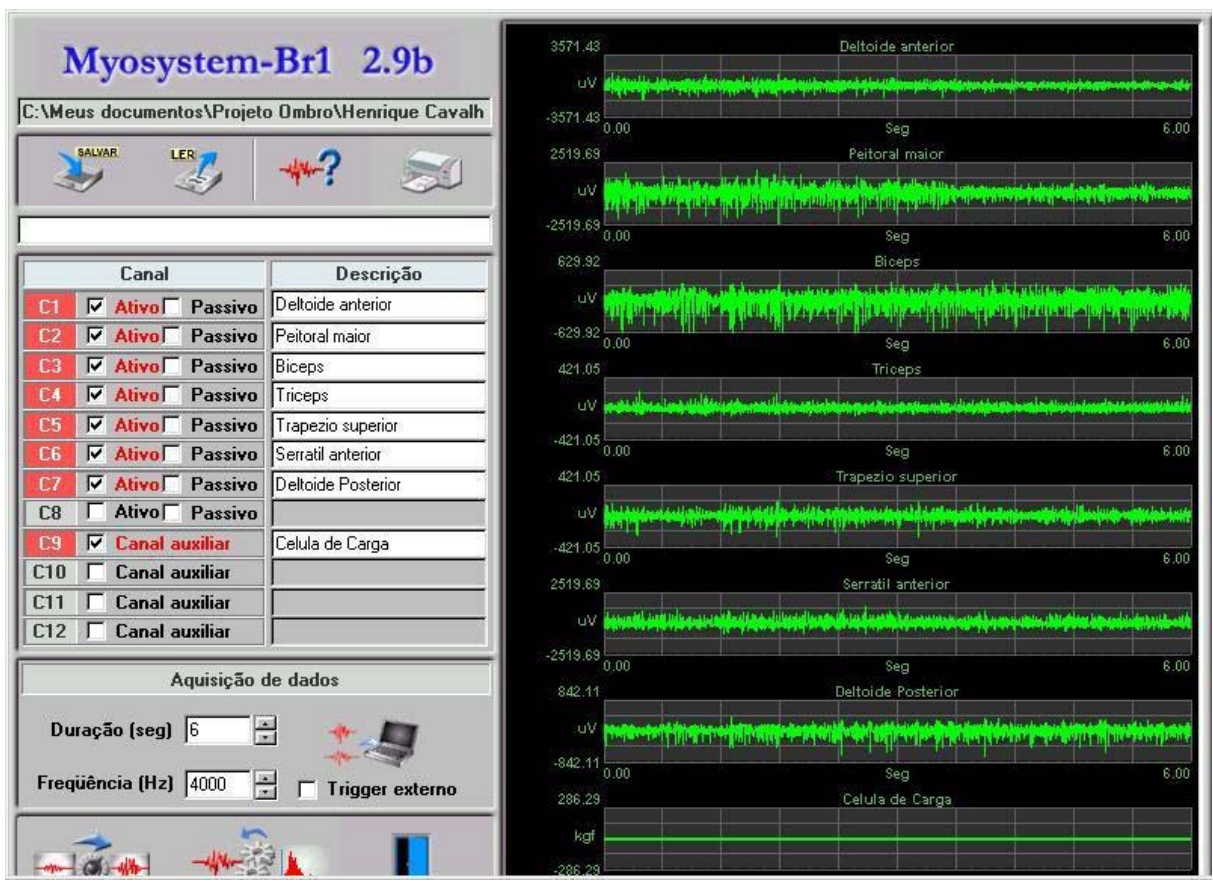

Figura 2. Interface da aquisição de dados do programa Myosystem $\mathrm{Br}-1$ versão 2.9b., ilustrando o resultado de uma coleta de registro eletromiográfico e de esforço máximo durante o exercício benchpress.

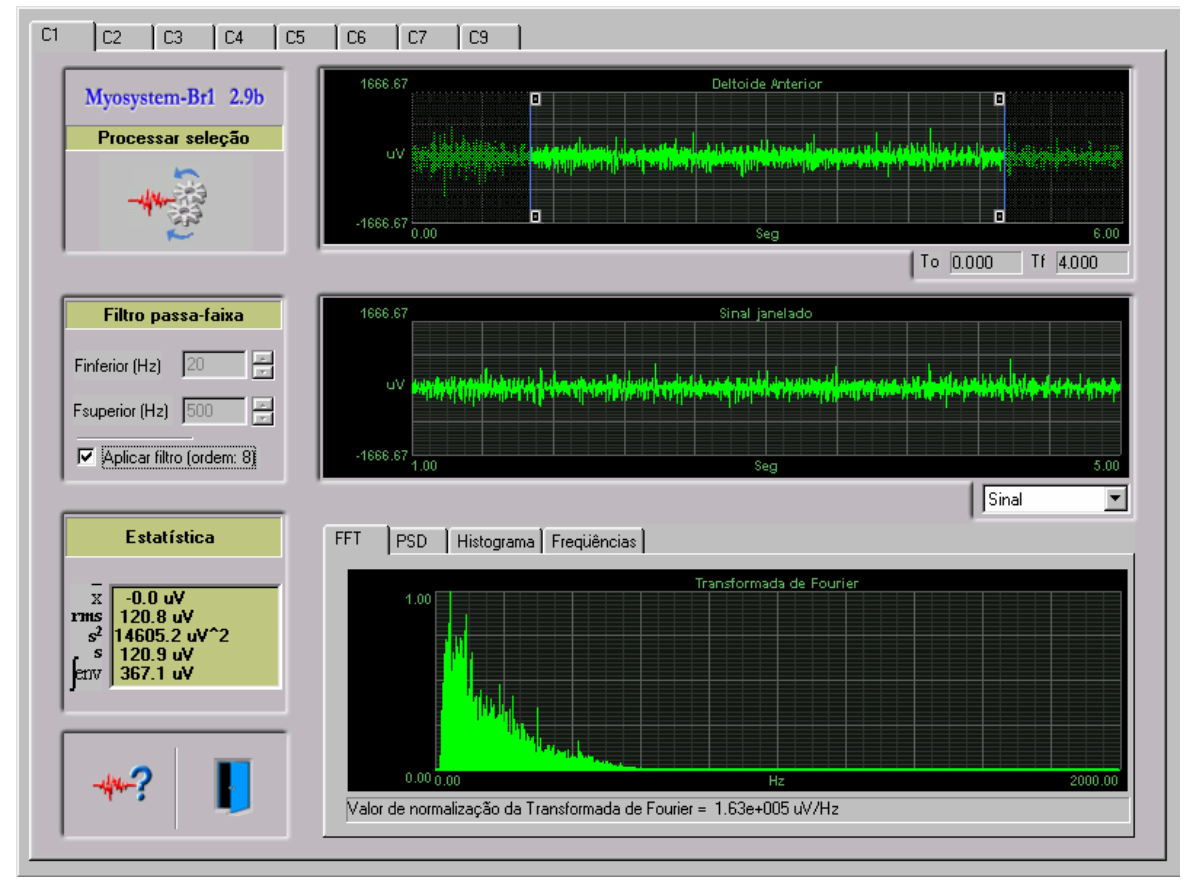

Figura 3. Interface do processamento de dados do programa Myosystem $\mathrm{Br}-1$ versão $2.9 \mathrm{~b}$, ilustrando o processamento do sinal eletromiográfico da porção anterior do músculo deltóide durante o exercício bench-press. 


\subsubsection{Eletrodos}

Os sinais mioelétricos foram captados por eletrodos ativos de superfícies simples diferencial compostos por duas barras retangulares paralelas $(10 \times 2 \times 1 \mathrm{~mm})$, de prata pura $(\mathrm{Ag})$, espaçadas entre si em $10 \mathrm{~mm}$ e fixadas em um encapsulado de resina acrílica de $20 \times 41 \times 5 \mathrm{~mm}$, da EMG System do Brasil (Figura 4). Estes eletrodos possuem impedância de entrada maior que $10 \mathrm{G} \Omega$, Razão de Rejeição de Modo Comum de $130 \mathrm{~dB}$ e ganho de 20 vezes. Também foi utilizado um eletrodo de referência de aço inoxidável com tamanho de $3 \mathrm{~cm}^{2}$ (Figura 5), da BIO-Logic (BIOLogic - Campinas, Brasil), posicionado na região do manúbrio esternal, usando gel condutor como meio acoplador, com a função de diminuir o efeito de interferências eletromagnéticas e outros ruídos de aquisição do sinal eletromiográfico.

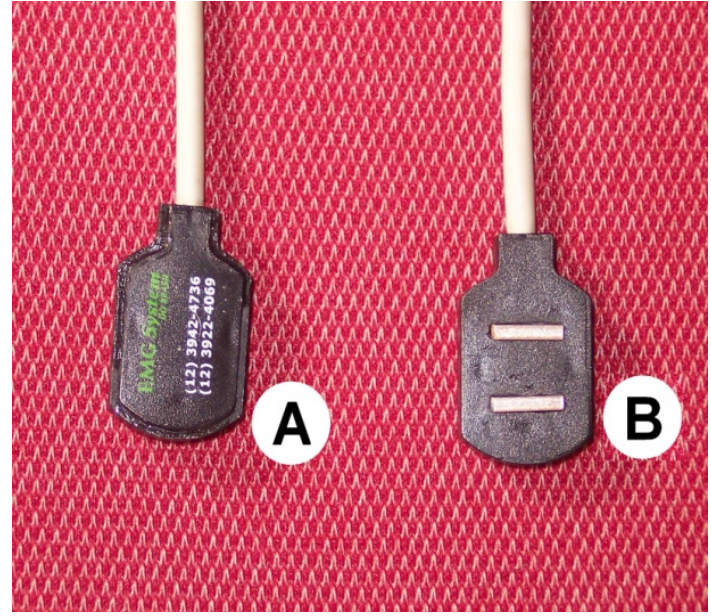

Figura 4. Eletrodos de superfície simples diferencial A. Face posterior. B. Superfície de contato do eletrodo.

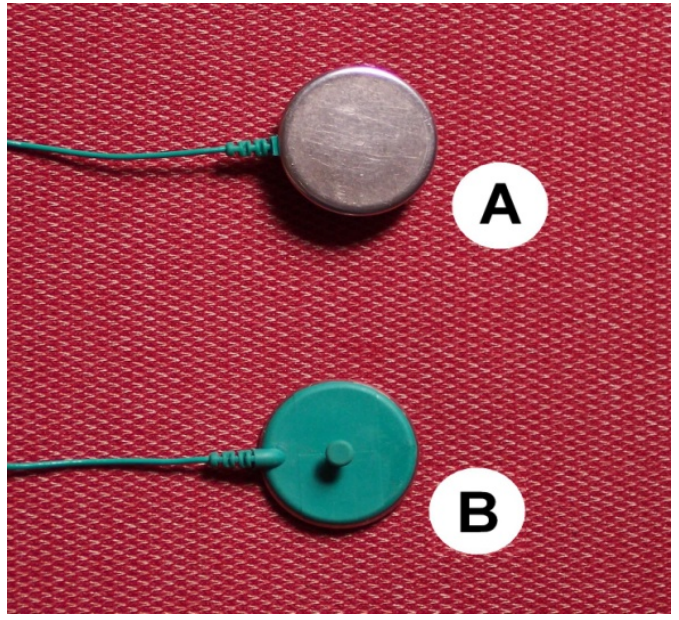

Figura 5. Eletrodos de referência A. Face posterior. B. Superfície de contato do eletrodo de referência.

\subsubsection{Célula de Carga e Condicionador de Sinais}

A força produzida foi captada por uma célula de carga Modelo MM da Kratos Dinamômetros LTDA., com capacidade nominal de 100 kgf (Figura 6), acoplada a um dos canais auxiliares do eletromiógrafo através de um condicionador de sinais (Figura 7). Ela foi posicionada em série entre um suporte específico para cada exercício e 
uma superfície estável utilizada para o apoio da mão do voluntário durante a realização de cada exercício. A célula de carga foi calibrada em cada exercício através do condicionador de sinais e do ajuste dos valores de força previamente determinados para cada voluntário em cada um dos exercícios. Os registros de força foram captados de maneira simultânea aos registros eletromiográficos.

Durante a captação da força muscular, um feedback sonoro serviu como referência para a força realizada pelo voluntário durante a execução do exercício. 0 feedback sonoro é uma ferramenta opcional do programa Myosystem $\mathrm{Br}$-1 versão 2.9b e o seu disparo é simultâneo ao início do registro de força e do sinal eletromiográfico. O voluntário foi instruído sobre os três diferentes tipos de alerta sonoro que ouviria durante o tempo de realização do exercício. O feedback sonoro foi ajustado para permitir uma faixa de variação de $10 \%$ no valor de força determinado, pois segundo o fabricante, essa variação no valor registrado é inerente ao equipamento.

A "ausência de um sinal sonoro" foi utilizada para indicar ao voluntário que ele estava realizando um esforço isométrico abaixo do valor previamente definido para aquele exercício. O sinal sonoro de "aplausos" indicou ao voluntário que a quantidade de esforço realizado era o ideal para aquele exercício e um terceiro sinal, de uma "sirene", seria emitido quando um esforço isométrico acima do adequado fosse realizado (Figura 8). Ao final dos 6 segundos de coleta foi dado um aviso ao voluntário de que a coleta havia sido encerrada, iniciando-se então um período de descanso de 1,5 minutos entre cada contração realizada. Um procedimento de familiarização prévio foi realizado com cada voluntário para a compreensão do procedimento experimental. 


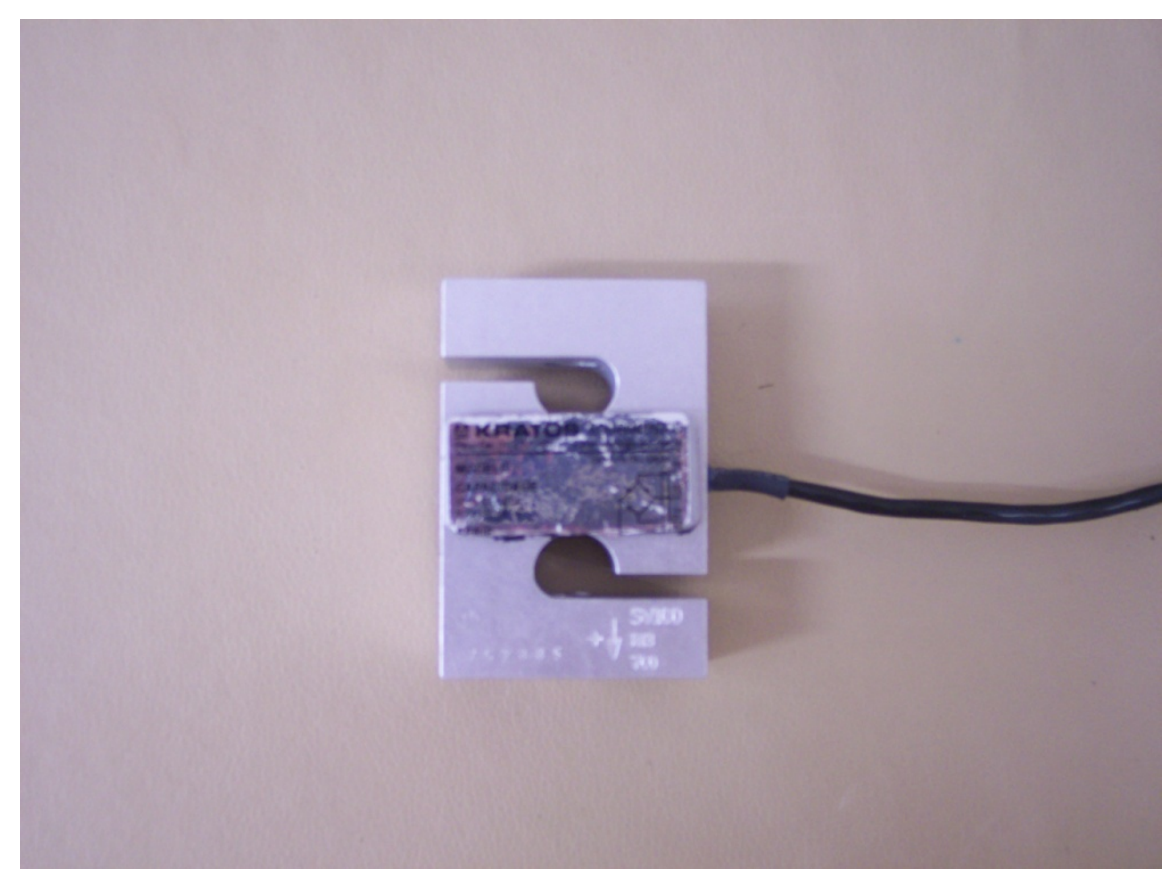

Figura 6. Célula de carga modelo MM da Kratos Dinamômetros LTDA. com capacidade nominal de $100 \mathrm{kgf}$.

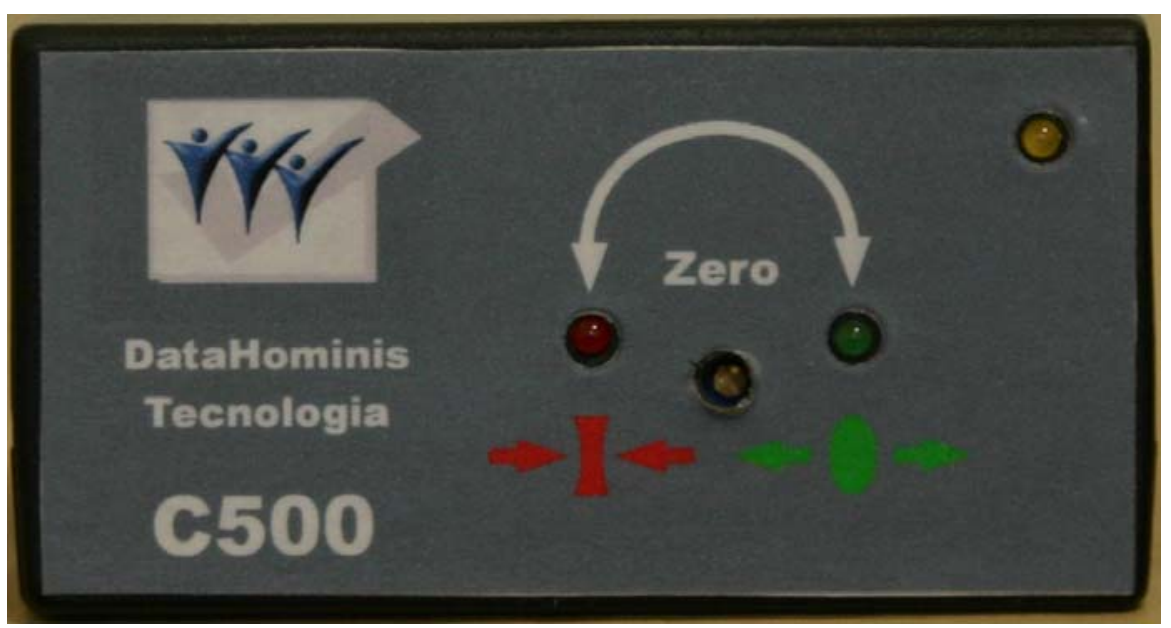

Figura 7. Condicionador de sinais modelo C500 da Data Hominis do Brasil. 


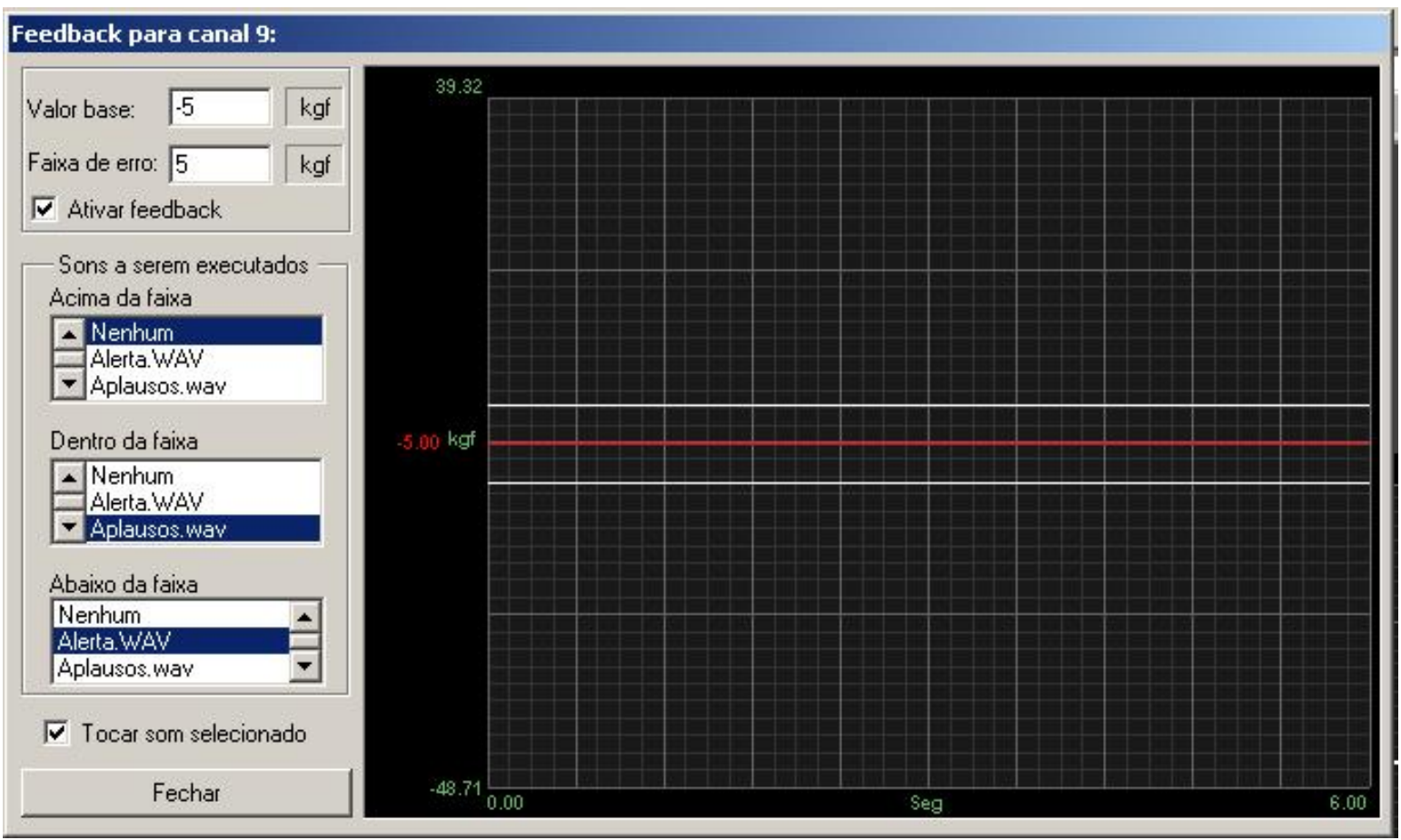

Figura 8. Interface de ajuste do feedback sonoro do programa Myosistem $\mathrm{Br}-1$ versão $2.9 b$.

\subsection{Superfície estável}

Uma plataforma de madeira de $0,20 \mathrm{~m}$ de largura $\times 0,30 \mathrm{~m}$ de comprimento foi utilizada como superfície estável. Possui em seu ponto central um parafuso, que permitiu fixá-la na célula de carga. O conjunto superfície estável-célula de carga foi acoplado nos suportes utilizados na pesquisa.

\subsection{Maca e Suportes para a realização dos exercícios}

Uma maca de $1,9 \mathrm{~m}$ de comprimento $\times 0,9 \mathrm{~m}$ de largura $\times 0,86 \mathrm{~m}$ de altura foi confeccionada para a execução do exercício bench-press. Um suporte de ferro formado por uma barra superior de $1,05 \mathrm{~m}$ e duas barras laterais de $1,5 \mathrm{~m}$ foi acoplado à maca. A barra superior possui em sua superfície inferior 5 furos espaçados entre si em $5 \mathrm{~cm}$, que permitiu tanto a regulagem quanto a fixação da célula de carga 
e da superfície estável. As barras laterais possuem uma braçadeira para a regulagem de altura deste suporte, permitindo o ajuste adequado ao voluntário durante a realização deste exercício (Figura 9).

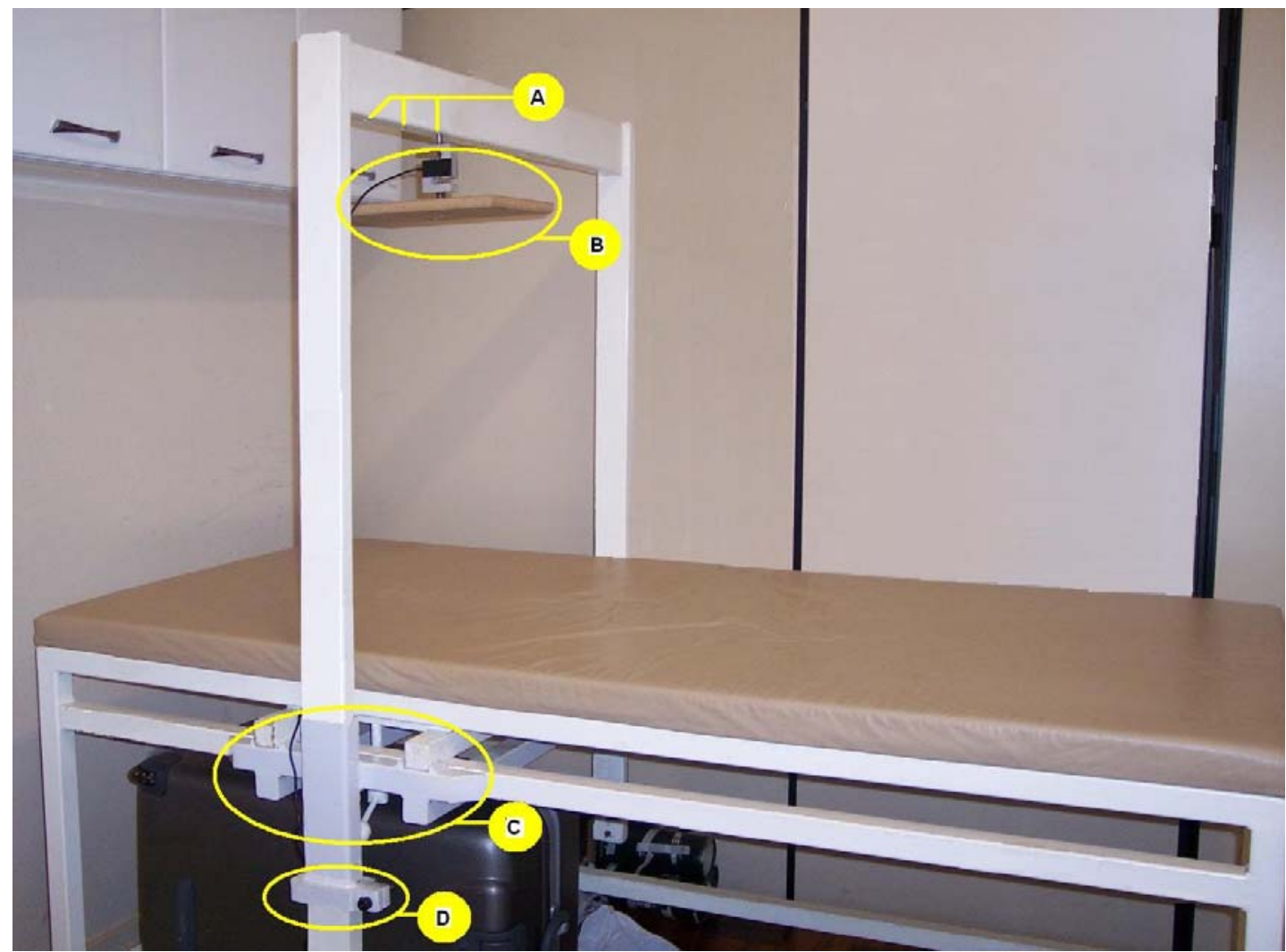

Figura 9. Maca para realização do exercício bench-press: A. Furação para posicionamento da célula de carga. B. Célula de carga e superfície estável em posição de teste do exercício. C. Regulagem deslizante horizontal do suporte da maca. D. Regulagem deslizante vertical do suporte da maca.

Um suporte de ferro fixo na parede de $50 \mathrm{~cm}$ de altura $\times 8,5 \mathrm{~cm}$ de largura foi utilizado para a realização do exercício wall-press. Este suporte possui 9 furos espaçados entre si em $5 \mathrm{~cm}$, que permitiram a regulagem de altura da superfície estável em relação a cada voluntário (Figura 10). 


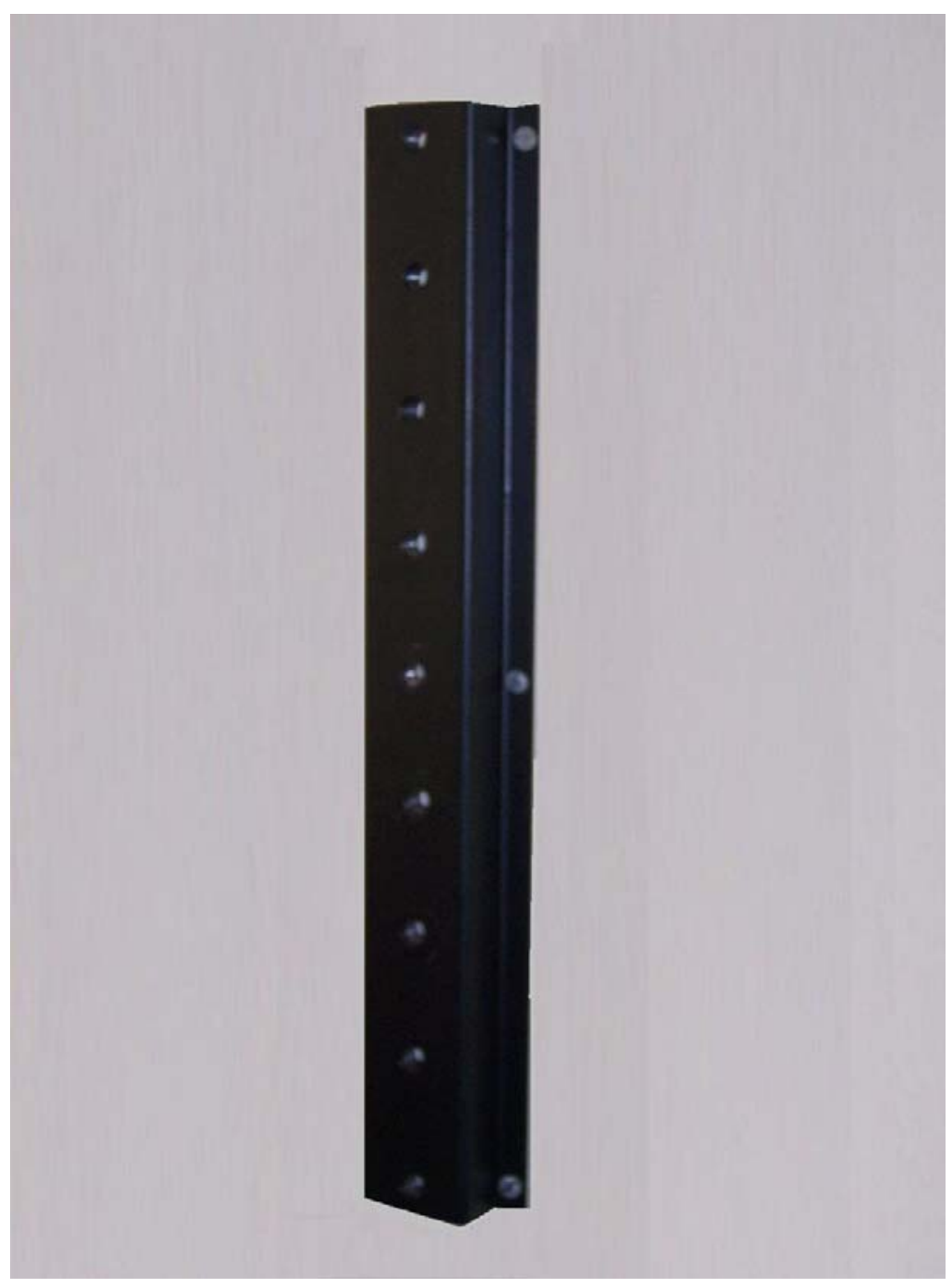

Figura 10. Suporte com furação para regulagem de altura para célula de carga e plataforma estável utilizado para a realização do exercício wall-press.

O exercício push-up foi realizado sobre a superfície estável acoplada a um suporte de madeira de 0,4 $\mathrm{m}$ de comprimento $\times 0,25 \mathrm{~m}$ de largura, que permaneceu no solo durante a realização do exercício. Este suporte possui uma barra de ferro fixa de $20 \mathrm{~cm}$ de comprimento $\times 8,5 \mathrm{~cm}$ de largura, que contém 3 furos espaçados entre si em $5 \mathrm{~cm}$ para fixação da célula de carga e da superfície estável (Figuras 11 e 12). 


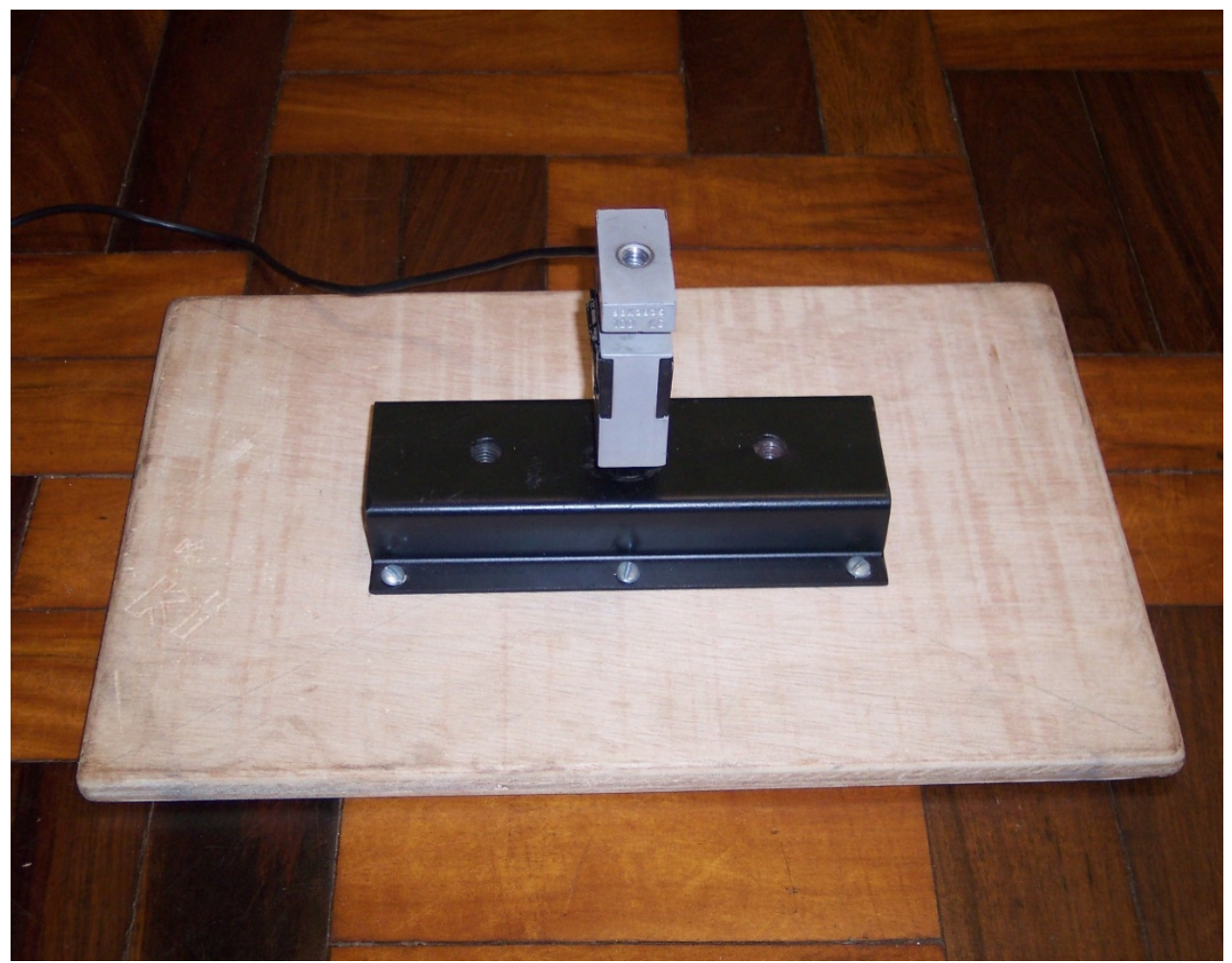

Figura 11. Suporte de madeira para montagem do exercício push-up

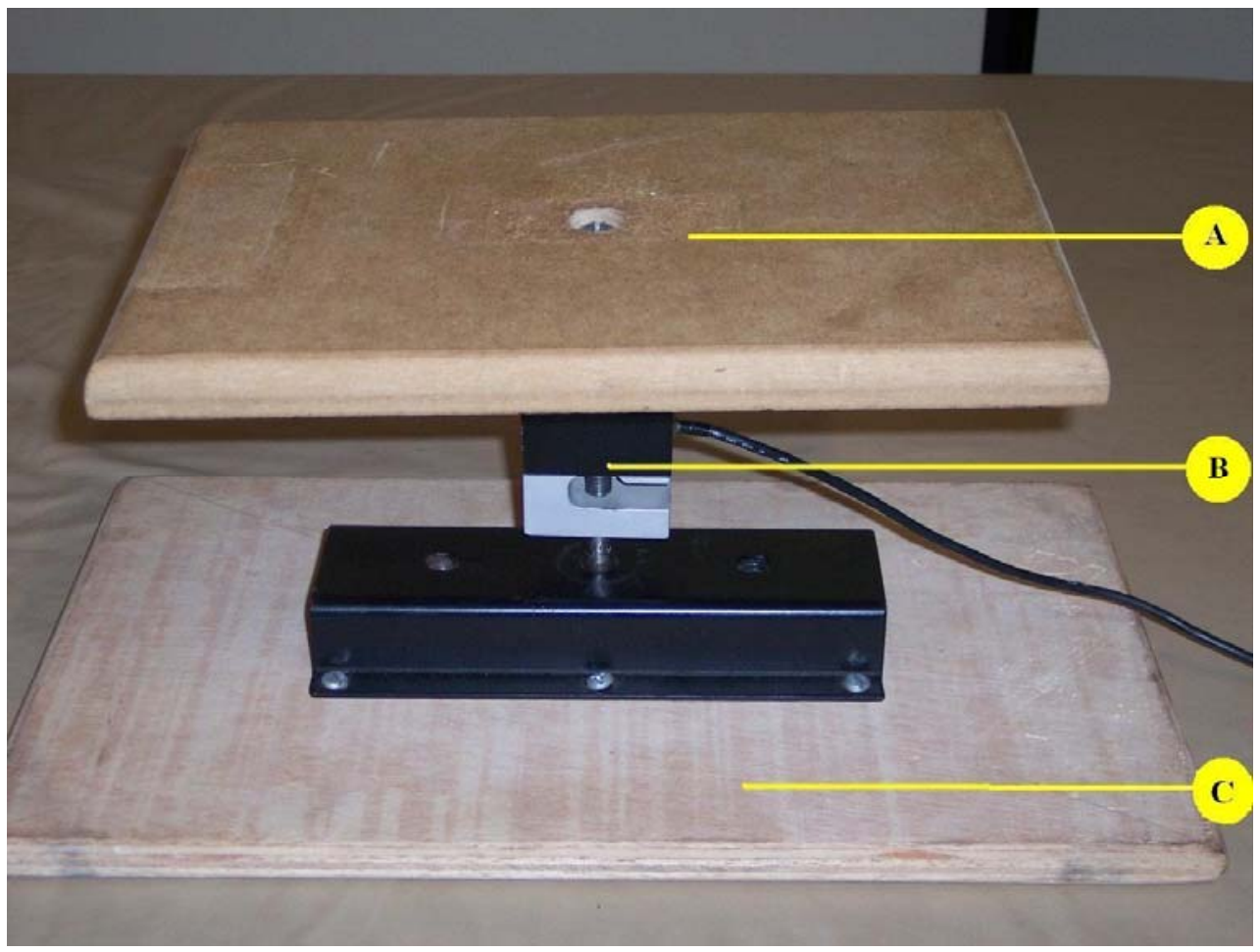

Figura 12. Vista lateral dos equipamentos para a execução do exercício push-up. A. Superfície Estável. B. Célula de Carga C. Suporte de madeira. 


\subsection{Procedimento e Coleta dos Dados}

O procedimento completo para cada voluntário durante esta pesquisa foi dividido em duas etapas. A primeira etapa constou da explanação sobre a pesquisa, avaliação física, coleta da carga máxima para cada um dos exercícios e dos valores eletromiográficos da contração isométrica voluntária máxima (CIVM) de cada um dos músculos estudados. Após 48 horas de descanso mínimo, visando à recuperação do esforço da primeira etapa, cada voluntário realizou três vezes cada exercício de forma aleatória com 1,5 minutos de descanso entre cada repetição e 5 minutos de descanso entre um exercício e o outro.

A carga máxima, estabelecida para cada voluntário e em cada exercício, foi determinada pela média dos três valores registrados pela célula de carga durante a realização de três esforços isométricos máximos em cada um dos exercícios propostos, servindo como referência para os valores de $100 \%$ do esforço isométrico máximo. O valor de esforço isométrico máximo (100\%) obtido em cada exercício serviu como valor de referência para o cálculo de $80 \%$ do esforço isométrico máximo do próprio exercício. O feedback sonoro foi utilizado para monitorar o voluntário sobre os níveis de esforço produzidos, permitindo a manutenção dos valores estabelecidos dentro de uma variação máxima permitida de $10 \%$ do valor estabelecido, variação considerada inerente ao equipamento segundo informações do fabricante. O tempo de duração da coleta da atividade eletromiográfica foi de 6 segundos e permaneceu o mesmo para todos os exercícios.

Após a exposição do procedimento experimental e dos objetivos da pesquisa, foi solicitado ao voluntário que lesse e assinasse o termo de consentimento formal de participação na pesquisa. Posteriormente, foi realizado o preenchimento dos dados da ficha de avaliação e a realização dos testes específicos, para assegurar os critérios de inclusão e exclusão estabelecidos. 
Antes da colocação dos eletrodos, foram realizadas a limpeza e tricotomia da pele. A colocação dos eletrodos na porção anterior e na porção posterior do músculo deltóide, na cabeça longa do músculo bíceps braquial e do músculo tríceps braquial e na porção superior do músculo trapézio foi orientada pela European Recommendations for Surface Electromyography do Projeto SENIAN (HERMENS et al., 1999). Pelo fato do projeto SENIAN não possuir nenhuma recomendação para os músculos serrátil anterior e porção clavicular do músculo peitoral maior, foi seguida a colocação sugerida por Hintermeinster et al. (1998). A descrição da colocação destes eletrodos encontra-se na tabela 2. A fixação dos eletrodos foi realizada com tiras de esparadrapo, permitindo o melhor acoplamento entre as barras de captação e a pele do voluntário. Essa padronização de colocação dos eletrodos foi seguida tanto durante a primeira fase do procedimento, durante a coleta das contrações isométricas voluntárias máximas, como durante a segunda etapa, na coleta dos registros eletromiográficos dos exercícios.

Para a obtenção dos valores de referência para normalização dos valores de RMS para cada um dos músculos estudados, foram realizadas três contrações isométricas voluntárias máximas, com duração de 6 segundos cada, na posição de prova de função muscular (KENDALL, KENDALL; PROVANCE, 1997, EKSTROM;DONATELLI; SODEBERG, 2003). A seqüência das contrações musculares foi determinada aleatoriamente. Durante a realização da prova de função muscular, foi mantido o comando verbal "FORÇA, FORÇA, FORÇA" durante os 6 segundos de coleta. Tanto as provas de função muscular quanto o comando verbal foram feitos pelo mesmo examinador durante todo o experimento.

A segunda etapa teve início com o sorteio dos exercícios, como forma de aleatorizar a ordem de execução. Todos os voluntários realizaram três repetições de cada exercício, com duração de 6 segundos e intervaladas entre si em 1,5 minuto, para evitar uma possível fadiga muscular. Este procedimento foi realizado a $100 \%$ e $80 \%$ do esforço isométrico máximo obtido durante a primeira etapa, correspondente aos exercícios testados. 
Tabela 2. Modo de colocação dos eletrodos segundo orientações da Recommendations for Surface Electromyography do Projeto SENIAN Hermens et al. (1999) e de Hintermeinster et al. (1998)
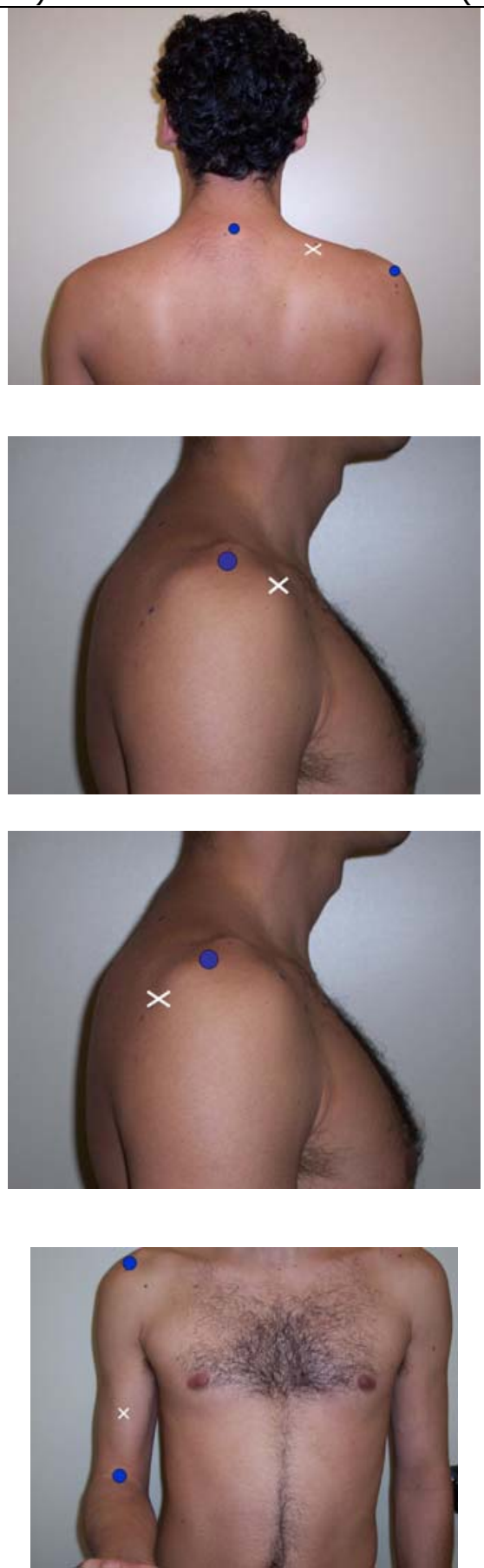

Músculo: Fibras superiores do músculo Trapézio

Origem: Protuberância occipital externa, terço medial da linha nucal superior, ligamento nucal e processo espinhoso da sétima vértebra cervical

Inserção: Terço lateral da clavícula e processo do acrômio da escápula

Posicionamento inicial: Sentado com os braços ao longo do corpo e antebraço pronado

Colocação dos eletrodos: O eletrodo deve ser posicionado no terço médio de uma linha imaginária entre o acrômio e a sétima vértebra cervical.

Músculo: Fibras anteriores do músculo Deltóide

Origem: Borda anterior, superfície anterior e terço lateral da clavícula

I nserção: Tuberosidade deltóidea do úmero

Posicionamento inicial: Sentado com os braços ao longo do corpo e antebraço pronado

Colocação dos eletrodos: O eletrodo deve ser posicionado um dedo distal e um dedo anterior anterior ao acrômio

Músculo: Fibras posteriores do músculo Deltóide Origem: Lábio inferior da borda lateral da espinha da escápula

I nserção: Tuberosidade deltóidea do úmero

Posicionamento inicial: Sentado com os braços ao longo do corpo e antebraço pronado

Colocação dos eletrodos: O eletrodo deve ser posicionado dois dedos (do voluntário) atrás do ângulo do acrômio

Músculo: Cabeça longa do músculo Bíceps Braquial

Origem: Tubérculo supraglenóideo da escápula Inserção: Tuberosidade do rádio e aponeurose do bíceps braquial Posicionamento inicial: Sentado em uma cadeira, com o cotovelo flexionado em $90^{\circ}$ e antebraço pronado

Colocação dos eletrodos: O eletrodo deve ser posicionado no terço distal de uma linha entre o acrômio e a fossa cubital

x - posicionamento do eletrodo; • - origem e inserção muscular 
Tabela 2. (Continuação) Modo de colocação dos eletrodos segundo orientações da Recommendations for Surface Electromyography do Projeto SENIAN Hermens et al. (1999) e de Hintermeinster et al. (1998) (Continuação).

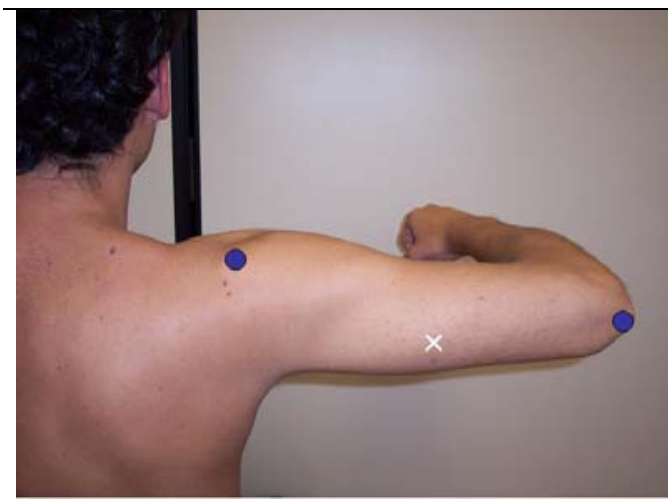

Músculo: Cabeça longa do músculo Tríceps Braquial

Origem: Tubéculo infraglenóide da escápula Inserção: Superfície posterior do olécrano e fáscia antebraquial.

Posicionamento inicial: Sentado, com abdução de ombro e flexão do cotovelo em $90^{\circ}$ e com o antebraço pronado.

Colocação dos Eletrodos: O eletrodo deve ser posicionado dois dedos (do voluntário) em sentido medial ao valor médio da linha formada entre a crista do acrômio e o olécrano

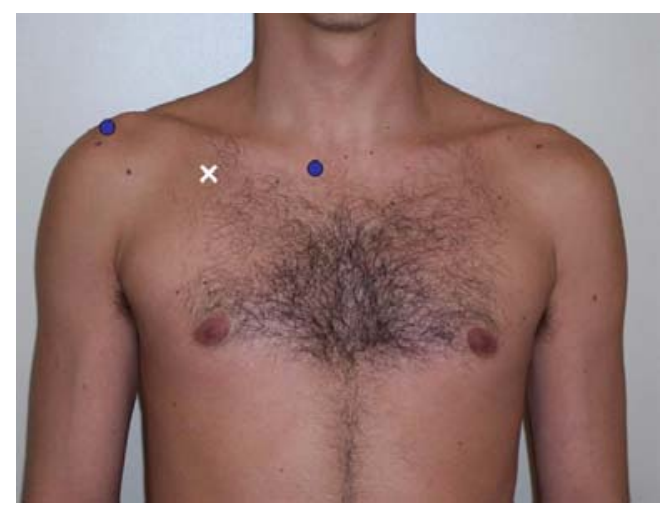

Músculo: Porção clavicular do músculo Peitoral Maior

Origem: Superfície anterior da metade esternal da clavícula

Inserção: Crista do tubérculo maior do úmero

Posicionamento inicial: Voluntário sentado com os braços ao longo do corpo

Colocação dos eletrodos: 5 centímetros abaixo da linha entre a articulação esternoclavicular e a cabeça do úmero, em seu terço proximal.

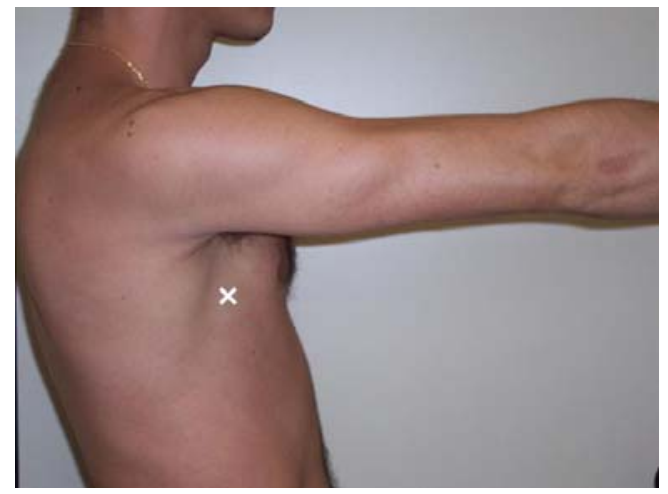

Músculo: Músculo Serrátil Anterior

Origem: Superfícies externas e bordas superiores das oito ou nove costelas superiores

Inserção: Superfície costal da borda medial da escápula

Posicionamento inicial: Voluntário sentado com o membro superior fletido em $90^{\circ}$

Colocação dos eletrodos: $\mathrm{Na}$ região abaixo da axila entre a borda anterior do músculo grande dorsal e a borda posterior do músculo peitoral maior

$\mathbf{x}$ - posicionamento do eletrodo; • - origem e inserção muscular. 


\subsection{Exercícios Propostos}

Cada voluntário realizou três diferentes exercícios isométricos de forma aleatória, em superfície estável, com a extremidade distal do segmento fixa e carga axial controlada. Todos os exercícios foram realizados com o membro superior dominante posicionado com o braço em $90^{\circ}$ de flexão no plano sagital, antebraço em $0^{\circ}$ de extensão do cotovelo e $90^{\circ}$ de extensão da mão.

Wall-press: voluntário em posição ortostática, com o membro superior dominante em $90^{\circ}$ de flexão de braço no plano sagital e mão em $90^{\circ}$ de extensão. Os voluntários realizaram este exercício empregando uma força de compressão axial a 100\% e 80\% do esforço isométrico máximo (Figura 13)

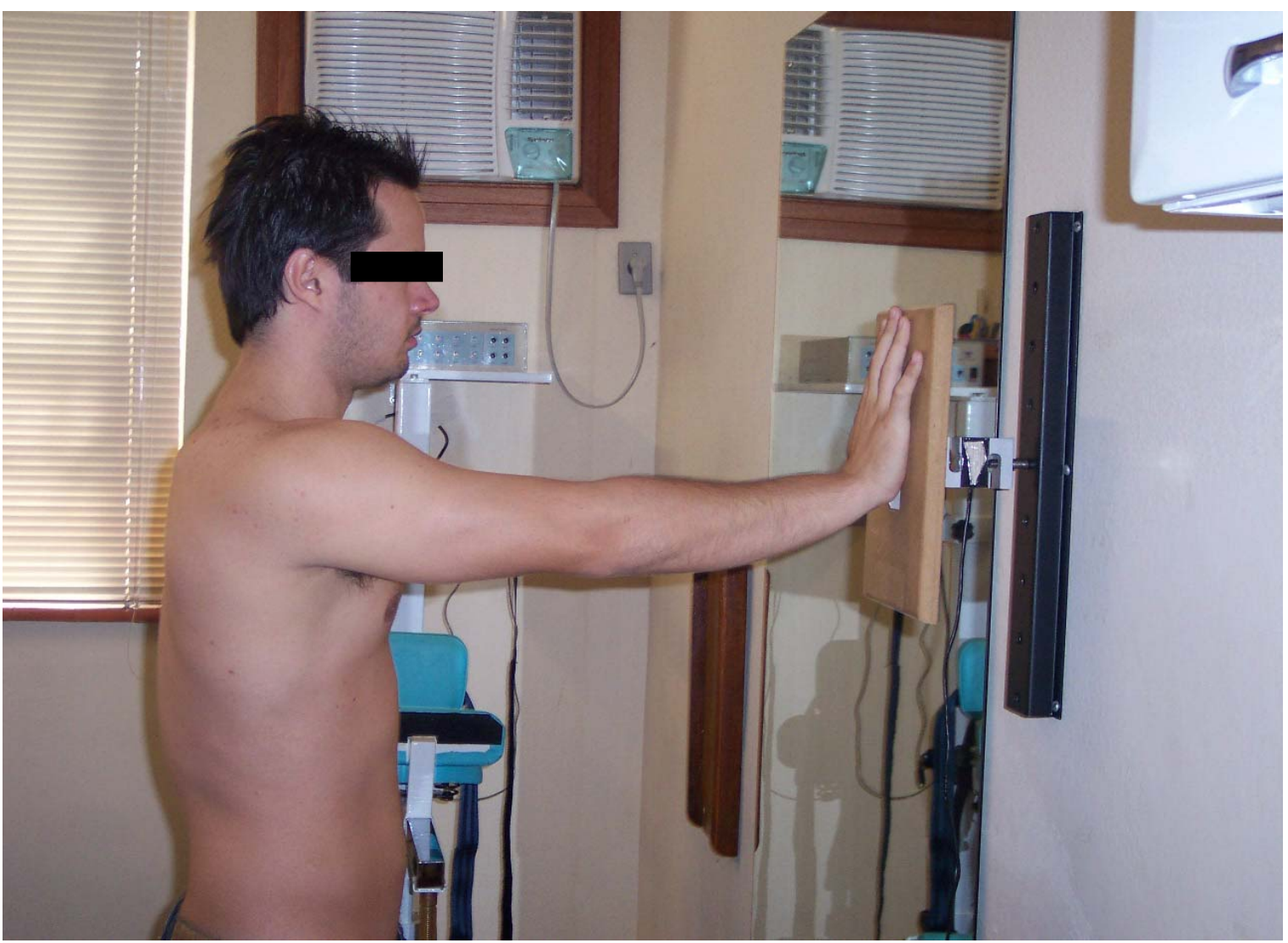

Figura 13: Exercício wall-press realizado em superfície estável. 
Bench-press: voluntário em decúbito dorsal, com os pés apoiados na maca, membro superior dominante a $90^{\circ}$ de flexão de braço e $90^{\circ}$ de extensão de punho. Os voluntários realizaram este exercício empregando uma força de compressão axial a $100 \%$ e $80 \%$ do esforço isométrico máximo (Figura 14).

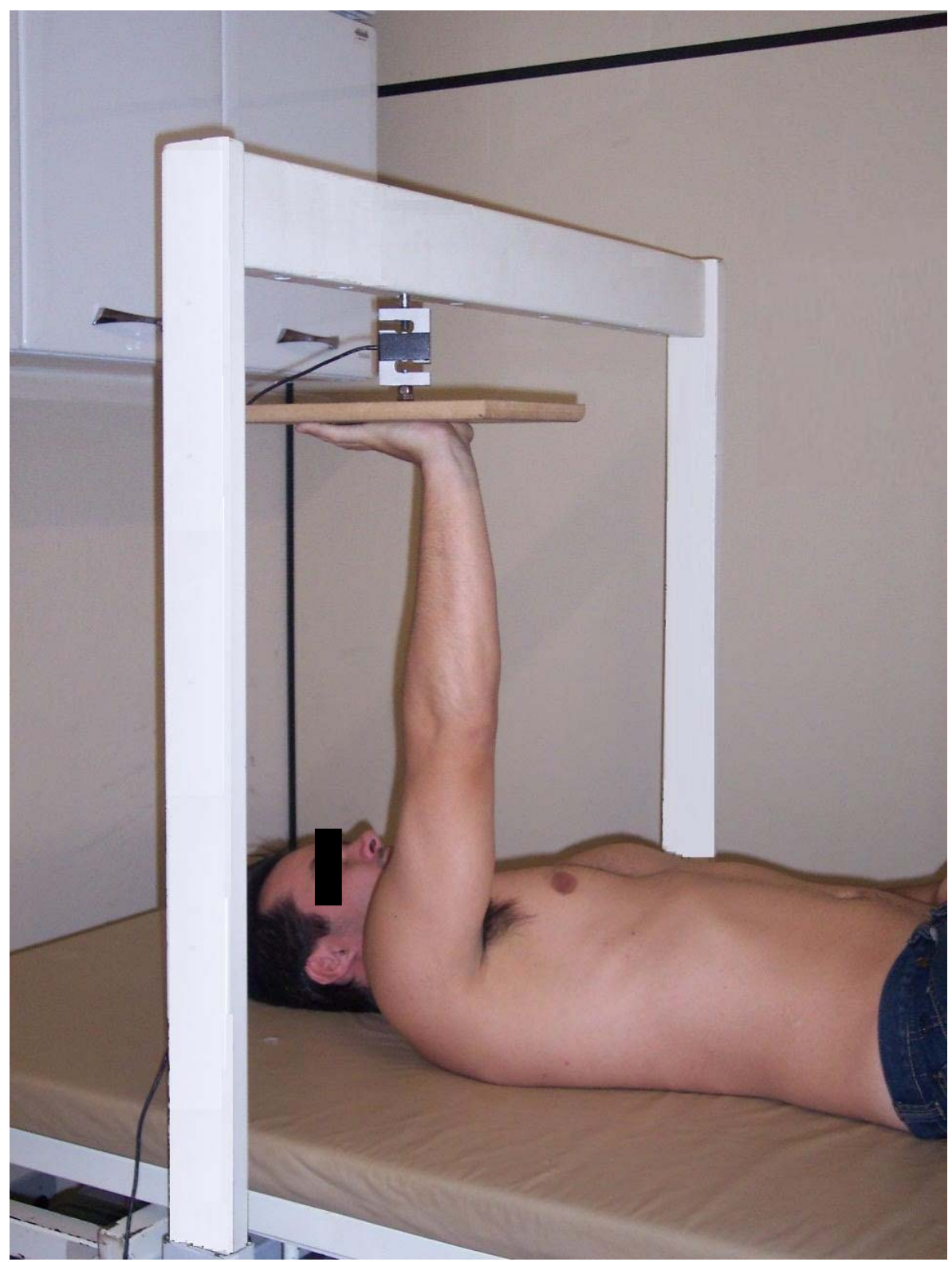

Figura 14: Exercício bench-press realizado em superfície estável. 
Push-up: voluntário em decúbito ventral, com coxa e perna em $90^{\circ}$ de flexão, posição neutra de tronco e com o membro superior dominante em $90^{\circ}$ de flexão de braço e mão em $90^{\circ}$ de extensão. Um caixote de madeira foi posicionado sob os joelhos do voluntário para adequação de sua postura nos exercícios. Os voluntários realizaram este exercício empregando uma força de compressão axial a 100\% e $80 \%$ do esforço isométrico máximo (Figura 15).

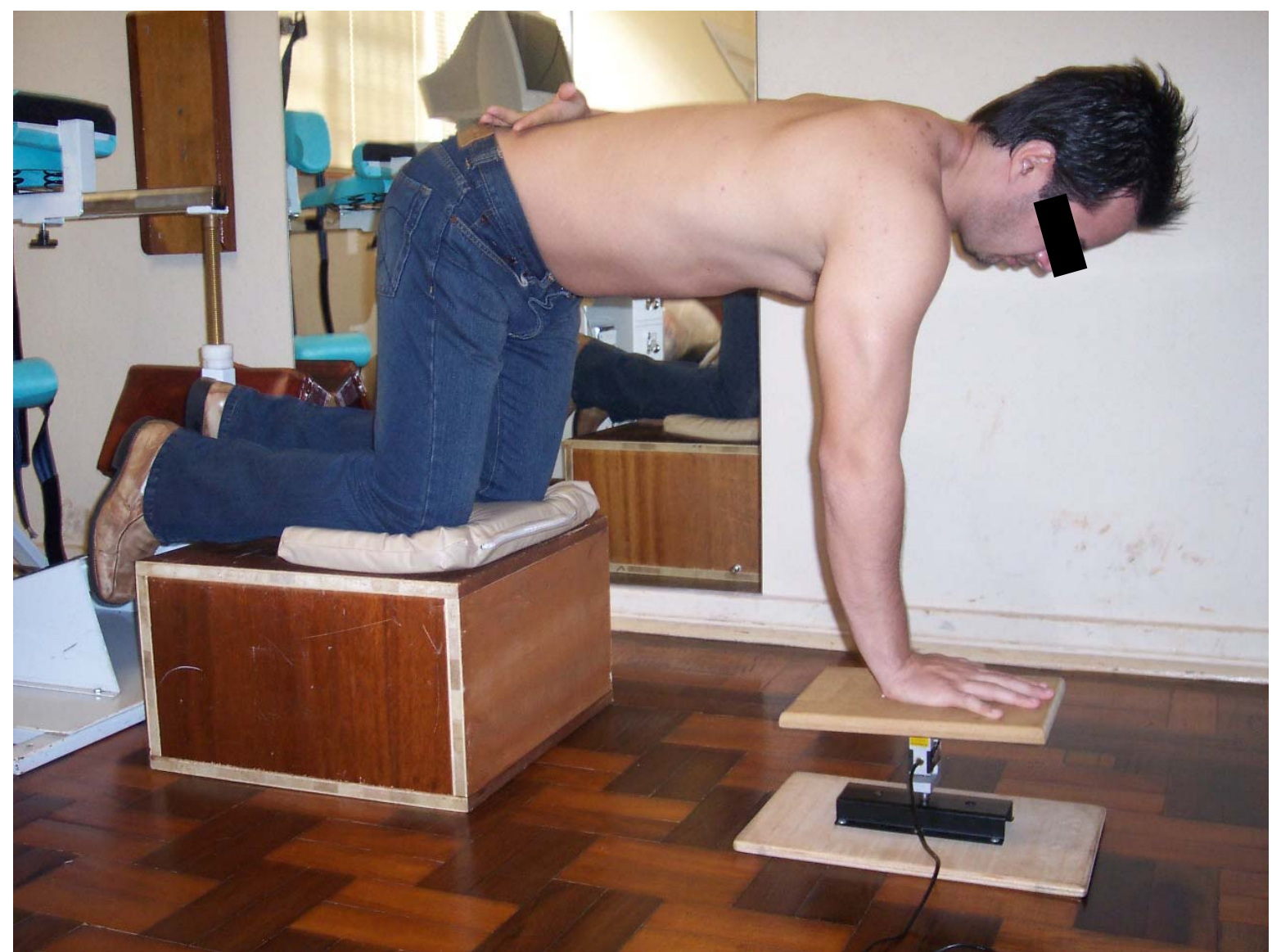

Figura 15: Exercício push-up realizado em superfície estável. 


\subsection{Análise dos Dados}

A análise dos dados foi realizada com janelamento do sinal em 4 segundos dos 6 segundos coletados, sendo o primeiro e o último segundo da coleta excluídos da análise. Essa exclusão foi utilizada em decorrência do tempo que o voluntário demorou a estabilizar a quantidade de carga pré-estabelecida, o que ocorria logo no primeiro segundo. Assim, os quatros segundos intermediários da coleta apresentaram o sinal eletromiográfico visualmente mais homogêneo e compatível com o nível de esforço desejado.

Foram obtidos traçados eletromiográficos brutos dos valores em microvolts do Root Mean Square (RMS) para os registros dos exercícios realizados. Os sinais eletromiográficos brutos foram filtrados digitalmente com um filtro passa-faixa de 20 $500 \mathrm{~Hz}$ e, posteriormente, normalizados. O procedimento de normalização foi feito pela razão entre o valor médio de RMS obtido de cada músculo em cada exercício pelo valor máximo de RMS obtido dos registros da CIVM para cada músculo correspondente. Estes dados foram utilizados para a comparação da atividade eletromiográfica dos músculos avaliados entre os três exercícios nos dois diferentes níveis de esforço isométrico máximo e entre o mesmo exercício nos dois níveis de esforço isométrico máximo.

Os dados normalizados também foram referidos em valores percentuais em cada exercício para os dois níveis de carga com a finalidade de expressar os níveis de atividade eletromiográfica que cada exercício foi capaz de gerar. Para descrever o nível de atividade foi utilizada a classificação proposta por Di Giovine et al. (1992), que considerou a atividade como mínima se menor que $20 \%$, moderada entre $20 \%$ $40 \%$, alta entre de $41 \%-60 \%$ e muito alta acima de $61 \%$. 


\subsection{Análise Estatística}

Com o propósito de avaliar a influência do esforço isométrico na comparação dos valores normalizados de RMS durante as comparações propostas neste trabalho foi utilizado o modelo linear de efeitos mistos (MCLEANS, SANDER; SROUP, 1991). Este tipo de análise de dados é proposta quando as respostas de um mesmo indivíduo estão agrupadas e a suposição de independência entre as observações de um mesmo grupo não é adequada (SCHALL, 1991). No caso, as respostas (valores de RMS normalizados) podem ser consideradas como agrupadas por voluntários e a informação de cada um dos voluntários submetido a cada um dos exercícios é utilizada no modelo na forma de efeitos aleatórios. Após a construção do modelo, foi realizada uma análise de resíduos e a transformação logarítmica foi adequada para manter algumas suposições associadas ao modelo proposto. O modelo do ajuste foi realizado através do procedimento PRO MIXED do programa SAS, versão 8 (LITELL et al., 1996). Um nível de $5 \%(p<0,05)$ foi estabelecido para definir a significância estatística entre os valores comparados. 
"A maior recompensa pelo trabalho não é o que a pessoa ganha, mas o que ela se torna através dele"

John Ruskin

\section{Resultados}




\section{Resultados}

Neste capítulo serão apresentados os resultados referentes à comparação entre os três exercícios analisados nos dois diferentes níveis de esforço isométrico empregados e os resultados da comparação entre o mesmo exercício nos dois diferentes níveis de esforço isométrico.

Os níveis de atividade eletromiográfica obtida para os músculos avaliados, expressos em valores percentuais de RMS normalizado, serão expostos com a finalidade de demonstrar o nível de atividade eletromiográfica obtida em cada exercício nos dois níveis de esforço isométrico.

\subsection{Comparação da atividade eletromiográfica dos músculos avaliados entre os exercícios realizados com $\mathbf{1 0 0 \%}$ e $\mathbf{8 0} \%$ do esforço isométrico máximo}

O teste estatístico aplicado evidenciou que, quando comparados os valores normalizados de RMS dos músculos estudados entre os exercícios propostos, alguns dos valores de RMS normalizados dos músculos avaliados apresentaram diferença estatisticamente significativa $(p<0,05)$. O Modelo Linear de Efeitos Mistos demonstrou que as diferenças encontradas estão relacionadas aos resultados obtidos tanto da comparação entre os exercícios a $100 \%$ do esforço isométrico máximo quanto da comparação entre os exercícios a $80 \%$ do esforço isométrico máximo. Esses resultados encontram-se nas tabelas 3 e 4 . Os resultados referentes aos dois níveis de esforço isométrico.

Durante as comparações entre o wall-press e o bench-press, o valor de RMS normalizado da cabeça longa do músculo bíceps braquial e das fibras superiores do músculo trapézio apresentaram diferença estatisticamente significativa $(p<0,05)$, com maior valor de RMS normalizado no exercício wall-press em relação ao bench-press. Já os valores de RMS normalizados da cabeça longa do músculo tríceps braquial, do músculo serrátil anterior e das fibras posteriores do músculo deltóide apresentaram 
diferença estatisticamente significativa $(p<0,05)$, com maior valor de RMS normalizado no exercício bench-press em relação ao exercício wall-press (tabelas 3 e 4).

A comparação entre os exercícios bench-press e push-up demonstrou que o valor de RMS normalizado de alguns músculos apresentou diferença estatisticamente significativa $(p<0,05)$ tanto a $100 \%$ quanto a $80 \%$ do esforço isométrico máximo. Os valores de RMS normalizados das fibras anteriores do músculo deltóide, da cabeça longa do músculo tríceps braquial e do músculo serrátil anterior demonstraram atividade eletromiográfica significativamente maior no exercício bench-press em relação ao exercício push-up. O exercício push-up, em relação ao exercício benchpress, demonstrou atividade eletromiográfica significativamente maior para as fibras superiores do músculo trapézio (tabelas 3 e 4).

O exercício wall-press, em comparação ao push-up, apresentou atividade eletromiográfica significativamente maior das fibras anteriores do músculo deltóide, do músculo peitoral maior, da cabeça longa do músculo bíceps braquial e das fibras superiores do músculo trapézio, enquanto a cabeça longa do músculo tríceps braquial e as fibras posteriores do músculo deltóide apresentaram atividade eletromiográfica significativamente maior no exercício push-up, resultados referentes aos dois níveis de esforço isométrico máximo (tabelas 3 e 4). 
Tabela 3. Valores médios e desvios-padrão obtidos da comparação entre os valores de RMS normalizados pela contração isométrica voluntária máxima dos músculos avaliados durante os exercícios wall-press, bench-press e push-up realizados com $100 \%$ do esforço isométrico máximo $(n=15$ para DP e $n=20$ para os demais músculos).Unidade Arbitrária (U.A.)

\begin{tabular}{cccc}
\hline M & WP x BP 100\% & BP x PU 100\% & WP x PU 100\% \\
\hline DA & $0,23 \pm 0,02 \times 0,26 \pm 0,03$ & $0,26 \pm 0,03 \times 0,16 \pm 0,03^{*}$ & $0,23 \pm 0,02 \times 0,16 \pm 0,03^{*}$ \\
PM & $0,23 \pm 0,05 \times 0,20 \pm 0,02$ & $0,20 \pm 0,02 \times 0,10 \pm 0,04 *$ & $0,23 \pm 0,05 \times 0,10 \pm 0,04^{*}$ \\
BB & $0,12 \pm 0,02 \times 0,06 \pm 0,01^{*}$ & $0,06 \pm 0,01 \times 0,05 \pm 0,01$ & $0,12 \pm 0,02 \times 0,05 \pm 0,01 *$ \\
TB & $0,08 \pm 0,01 \times 0,46 \pm 0,03^{*}$ & $0,46 \pm 0,03 \times 0,25 \pm 0,05 *$ & $0,08 \pm 0,01 \times 0,25 \pm 0,05 *$ \\
TS & $0,19 \pm 0,02 \times 0,05 \pm 0,02^{*}$ & $0,05 \pm 0,02 \times 0,12 \pm 0,02 *$ & $0,19 \pm 0,02 \times 0,12 \pm 0,02 *$ \\
SA & $0,31 \pm 0,03 \times 0,47 \pm 0,03^{*}$ & $0,47 \pm 0,03 \times 0,33 \pm 0,02 *$ & $0,31 \pm 0,03 \times 0,33 \pm 0,02$ \\
DP & $0,07 \pm 0,02 \times 0,23 \pm 0,02 *$ & $0,23 \pm 0,02 \times 0,17 \pm 0,02$ & $0,07 \pm 0,02 \times 0,17 \pm 0,02 *$ \\
\hline
\end{tabular}

M (músculo); WP (wall-press); BP (bench-press); PU (push-up); DA (fibras anteriores do músculo deltóide); PM (peitoral maior); BB (bíceps braquial), TB (tríceps braquial); TS (fibras superiores do músculo trapézio); SA (serrátil anterior); DP (fibras posteriores do músculo deltóide).

*Modelo Linear de Efeitos Mistos: $p<0,05$

Tabela 4. Valores médios e desvios-padrão obtidos da comparação entre os valores de RMS normalizados pela contração isométrica voluntária máxima dos músculos avaliados durante os exercícios wall-press, bench-press e push-up realizados com $80 \%$ do esforço isométrico máximo $(n=15$ para DP e $n=20$ para os demais músculos).Unidade Arbitrária (U.A.)

\begin{tabular}{cccc}
\hline M & WP $\times$ BP 80\% & BP x PU 80\% & WP x PU 80\% \\
\hline DA & $0,15 \pm 0,010 \times 0,18 \pm 0,030$ & $0,18 \pm 0,030 \times 0,08 \pm 0,008^{*}$ & $0,15 \pm 0,010 \times 0,08 \pm 0,008^{*}$ \\
PM & $0,12 \pm 0,010 \times 0,14 \pm 0,020$ & $0,14 \pm 0,020 \times 0,05 \pm 0,020^{*}$ & $0,12 \pm 0,010 \times 0,05 \pm 0,020^{*}$ \\
BB & $0,07 \pm 0,007 \times 0,05 \pm 0,003^{*}$ & $0,05 \pm 0,003 \times 0,03 \pm 0,007$ & $0,07 \pm 0,007 \times 0,03 \pm 0,007 *$ \\
TB & $0,06 \pm 0,006 \times 0,33 \pm 0,020^{*}$ & $0,33 \pm 0,020 \times 0,21 \pm 0,020^{*}$ & $0,06 \pm 0,006 \times 0,21 \pm 0,020^{*}$ \\
TS & $0,13 \pm 0,020 \times 0,04 \pm 0,010^{*}$ & $0,04 \pm 0,010 \times 0,06 \pm 0,010^{*}$ & $0,13 \pm 0,020 \times 0,06 \pm 0,010^{*}$ \\
SA & $0,31 \pm 0,030 \times 0,37 \pm 0,030 *$ & $0,37 \pm 0,030 \times 0,21 \pm 0,010 *$ & $0,31 \pm 0,030 \times 0,21 \pm 0,010$ \\
DP & $0,05 \pm 0,010 \times 0,14 \pm 0,010 *$ & $0,14 \pm 0,010 \times 0,10 \pm 0,010$ & $0,05 \pm 0,010 \times 0,10 \pm 0,010 *$ \\
\hline
\end{tabular}

M (músculo); WP (wall-press); BP (bench-press); PU (push-up); DA (fibras anteriores do músculo deltóide anterior); PM (peitoral maior); BB (bíceps braquial), TB (tríceps braquial); TS (fibras superiores do músculo trapézio); SA (serrátil anterior); DP (fibras posterores do músculo deltóide).

* Modelo Linear de Efeitos Mistos: $p<0,05$ 


\subsection{Comparação da atividade eletromiográfica a $100 \%$ e $80 \%$ do esforço isométrico máximo para um mesmo exercício.}

O Modelo Linear de Efeitos Mistos demonstrou não haver diferença estatisticamente significativa $(p<0,05)$ entre os valores de RMS normalizados obtidos dos músculos avaliados ao serem comparados para um mesmo exercício nos dois diferentes níveis de esforço isométrico (tabela 5).

Tabela 5. Valores médios e desvios-padrão obtidos da comparação entre os valores de RMS normalizados pela contração isométrica voluntária máxima dos músculos avaliados durante o mesmo exercício realizado com $100 \%$ e $80 \%$ do esforço isométrico ( $n=15$ para DP e $n=20$ para os demais músculos). Unidade Arbitrária (U.A.)

\begin{tabular}{cccc}
\hline M & WP 100\% x WP 80\% & BP 100\% x BP 80\% & PU 100\% x PU 80\% \\
\hline DA & $0,23 \pm 0,02 \times 0,15 \pm 0,010$ & $0,26 \pm 0,030 \times 0,18 \pm 0,030$ & $0,16 \pm 0,03 \times 0,08 \pm 0,008$ \\
PM & $0,23 \pm 0,05 \times 0,12 \pm 0,010$ & $0,20 \pm 0,020 \times 0,14 \pm 0,020$ & $0,10 \pm 0,04 \times 0,05 \pm 0,020$ \\
BB & $0,12 \pm 0,02 \times 0,07 \pm 0,007$ & $0,06 \pm 0,001 \times 0,05 \pm 0,003$ & $0,05 \pm 0,01 \times 0,03 \pm 0,007$ \\
TB & $0,08 \pm 0,02 \times 0,06 \pm 0,006$ & $0,46 \pm 0,060 \times 0,33 \pm 0,020$ & $0,25 \pm 0,05 \times 0,21 \pm 0,020$ \\
TS & $0,19 \pm 0,02 \times 0,13 \pm 0,020$ & $0,05 \pm 0,020 \times 0,04 \pm 0,010$ & $0,12 \pm 0,02 \times 0,06 \pm 0,010$ \\
SA & $0,31 \pm 0,03 \times 0,23 \pm 0,020$ & $0,47 \pm 0,030 \times 0,37 \pm 0,030$ & $0,33 \pm 0,02 \times 0,21 \pm 0,010$ \\
DP & $0,05 \pm 0,01 \times 0,07 \pm 0,020$ & $0,23 \pm 0,020 \times 0,14 \pm 0,010$ & $0,17 \pm 0,02 \times 0,10 \pm 0,010$ \\
\hline
\end{tabular}

M (músculo); WP (wall-press); BP (bench-press); PU (push-up); DA (fibras anteriores do músculo deltóide); PM (peitoral maior); BB (bíceps braquial), TB (tríceps braquial); TS (fibras superiores do músculo trapézio); SA (serrátil anterior); DP (fibras posteriores do músculo deltóide posterior).

Durante o exercício wall-press, o músculo serrátil anterior teve uma atividade eletromiográfica significativamente maior que a dos demais músculos. As fibras anteriores do músculo deltóide tiveram atividade eletromiográfica igual a do peitoral maior e estes músculos tiveram atividade eletromiográfica significativamente maior que os demais, com exceção do serrátil anterior. Os músculos bíceps braquial e tríceps braquial tiveram igual atividade eletromiográfica, porém tiveram atividade eletromiográfica significativamente maior que as fibras posteriores do músculo deltóide e atividade eletromiográfica significativamente menor que os demais 
músculos. Por fim, as fibras superiores do músculo trapézio tiveram atividade eleromiográfica significativamente maior que as fibras posteriores do músculo deltóide e que os músculos bíceps braquial e tríceps braquial (tabela 6).

No exercício bench-press, o músculo serrátil anterior teve atividade eletromiográfica igual ao do músculo tríceps braquial e estes dois músculos tiveram atividade eletromiográfica significativamente maior quando comparados aos demais. As fibras anteriores e posteriores do músculo deltóide e o músculo peitoral maior tiveram igual atividade eletromiográfica. O músculo bíceps braquial teve atividade eletromiográfica igual a das fibras superiores do músculo trapézio e os dois músculos tiveram atividade eletromiográfica significativamente menor que os demais (tabela 6).

No exercício push-up, a atividade eletromiográfica do músculo serrátil anterior foi a maior e a do bíceps braquial foi a menor quando comparada a dos demais músculos e o tríceps braquial só não teve atividade eletromiográfica significativamente maior que o músculo serrátil anterior. O músculo peitoral maior e as fibras posteriores do músculo deltóide tiveram atividade eletromiográfica significativamente menor que os demais músculos, com exceção ao bíceps braquial. As fibras anteriores do músculo deltóide tiveram atividade eletromiográfica significativamente maior que as fibras superiores do músculo trapézio, que o músculo peitoral maior e bíceps braquial, enquanto que as fibras superiores do músculo trapézio só tiveram atividade eletromiográfica significativamente menor quando comparadas aos músculos tríceps braquial e serrátil anterior (tabela 6). 
Tabela 6. Valores médios e desvios-padrão obtidos da comparação entre a atividade eletromiográfica dos músculos estudados, referidas em valores de RMS normalizados, nos exercícios wall-press, bench-press e push-up com $100 \%$ e $80 \%$ do torque máximo. ( $n=15$ para DP e $n=20$ para os demais músculos). Unidade Arbitrária (U.A.)

\begin{tabular}{ccccccc}
\hline & \multicolumn{2}{c}{ Wall-press } & \multicolumn{2}{c}{ Bench-press } & \multicolumn{2}{c}{ Push-up } \\
\hline M & $\mathbf{1 0 0} \%$ & $\mathbf{8 0} \%$ & $\mathbf{1 0 0} \%$ & $\mathbf{8 0} \%$ & $\mathbf{1 0 0} \%$ & $\mathbf{8 0} \%$ \\
\hline DA & $0,23 \pm 0,020^{*}$ & $0,15 \pm 0,010^{*}$ & $0,26 \pm 0,030^{*}$ & $0,18 \pm 0,030^{*}$ & $0,16 \pm 0,030^{\bullet}$ & $0,08 \pm 0,008^{\bullet}$ \\
PM & $0,23 \pm 0,050$ & $0,12 \pm 0,010$ & $0,20 \pm 0,020$ & $0,14 \pm 0,020$ & $0,10 \pm 0,040$ & $0,05 \pm 0,020$ \\
BB & $0,12 \pm 0,020^{* *}$ & $0,07 \pm 0,007 * *$ & $0,06 \pm 0,001^{*}$ & $0,05 \pm 0,003^{* *}$ & $0,05 \pm 0,010$ & $0,03 \pm 0,007$ \\
TB & $0,08 \pm 0,020$ & $0,06 \pm 0,006$ & $0,46 \pm 0,060$ & $0,33 \pm 0,020$ & $0,25 \pm 0,050$ & $0,21 \pm 0,020$ \\
TS & $0,19 \pm 0,020$ & $0,13 \pm 0,020$ & $0,05 \pm 0,020$ & $0,04 \pm 0,010$ & $0,12 \pm 0,020$ & $0,06 \pm 0,010$ \\
SA & $0,31 \pm 0,030$ & $0,23 \pm 0,020$ & $0,47 \pm 0,030$ & $0,37 \pm 0,030$ & $0,33 \pm 0,020$ & $0,21 \pm 0,010$ \\
DP & $0,05 \pm 0,010$ & $0,07 \pm 0,020$ & $0,23 \pm 0,020$ & $0,14 \pm 0,010$ & $0,17 \pm 0,020$ & $0,10 \pm 0,010$ \\
\hline
\end{tabular}

M (músculo); DA (fibras anteriores do músculo deltóide); PM (peitoral maior); BB (bíceps braquial), TB (tríceps braquial); TS (fibras superiores do músculo trapézio);

SA (serrátil anterior); DP (fibras posteriores do músculo deltóide).

* diferença significativa em relação a todos os músculos, exceto em relação ao PM.

** diferença significativa em relação a todos os músculos, exceto em relação ao TB.

- diferença significativa em relação a todos os músculos, exceto em relação ao PM e DP.

"diferença significativa em relação a todos os músculos, exceto em relação ao TS.

- diferença significativa em relação a todos os músculos

Modelo Linear de Efeitos Mistos: $p<0,05$

\subsection{Análise da porcentagem de ativação eletromiográfica nos exercícios wall- press, bench-press e push-up.}

A tabela 7 ilustra os resultados da descrição dos valores de RMS normalizados, descritos em valores percentuais, referenciando a porcentagem da atividade eletromiográfica de cada músculo em cada exercício e nos dois níveis de esforço isométrico máximo. A porcentagem da atividade eletromiográfica foi considerada mínima se menor que $20 \%$, moderada de $21 \%-40 \%$, alta de $41 \%-60 \%$ e muito alta acima de 60\% (Di Giovine et al., 1992). De acordo com essa classificação, os exercícios empregados nesta pesquisa foram considerados adequados para fortalecer um músculo quando eles foram capazes de gerar atividade eletromiográfica dentro das porcentagens moderada, alta e muito alta.

Em relação às porcentagens de atividade eletromiográfica no exercício wallpress, os resultados demonstraram atividade moderada para a porção anterior do músculo deltóide, para o músculo peitoral maior e para o serrátil anterior a $100 \%$ do esforço isométrico máximo. Atividade moderada do serrátil anterior também foi 
registrada durante a realização deste exercício a $80 \%$ do esforço isométrico máximo. Os demais músculos foram ativados minimamente tanto a $100 \%$ quanto a $80 \%$ do esforço isométrico máximo.

O exercício bench-press ativou moderadamente a porção anterior do músculo deltóide e o peitoral maior e registro de ativação alta foi obtido para a cabeça longa do músculo tríceps braquial e para o músculo serrátil anterior quando realizado com $100 \%$ do torque isométrico máximo. Quando realizado a $80 \%$ do esforço isométrico máximo, este exercício ativou moderadamente a cabeça longa do músculo tríceps braquial e o serrátil anterior. Em relação aos demais músculos, a atividade foi considerada mínima nos dois valores de esforço empregados.

Durante a realização do exercício push-up, valores moderados de atividade foram obtidos para a cabeça longa do músculo tríceps braquial e para o serrátil anterior, nos dois valores de esforço isométrico máximo. Os demais músculos foram ativados minimamente, tanto a $100 \%$ quanto a $80 \%$ do esforço isométrico máximo.

Tabela 7. Porcentagem de atividade elétrica durante os exercícios wall-press, benchpress push-up, obtidas através de valores de RMS normalizados. Atividade mínima menor que $20 \%$, moderada entre $20 \%-40 \%$, alta entre $41 \%-60 \%$ e muito alta acima de $60 \%$. ( $n=15$ para DP e $n=20$ para os demais músculos)

\begin{tabular}{lcccccc}
\hline & \multicolumn{2}{c}{ Wall-Press } & \multicolumn{2}{c}{ Bench-press } & \multicolumn{2}{c}{ Push-up } \\
\hline M & $\mathbf{1 0 0} \%$ Força & $\mathbf{8 0} \%$ Força & $\mathbf{1 0 0} \%$ Força & $\mathbf{8 0} \%$ Força & $\mathbf{1 0 0} \%$ Força & $\mathbf{8 0} \%$ Força \\
\hline DA & $23 \%$ & $15 \%$ & $26 \%$ & $18 \%$ & $16 \%$ & $8 \%$ \\
PM & $23 \%$ & $12 \%$ & $20 \%$ & $14 \%$ & $10 \%$ & $5 \%$ \\
BB & $12 \%$ & $7 \%$ & $6 \%$ & $5 \%$ & $5 \%$ & $3 \%$ \\
TB & $8 \%$ & $6 \%$ & $46 \%$ & $33 \%$ & $25 \%$ & $21 \%$ \\
TS & $19 \%$ & $13 \%$ & $5 \%$ & $4 \%$ & $12 \%$ & $6 \%$ \\
SA & $31 \%$ & $23 \%$ & $47 \%$ & $37 \%$ & $33 \%$ & $21 \%$ \\
DP & $3 \%$ & $5 \%$ & $3 \%$ & $14 \%$ & $17 \%$ & $10 \%$ \\
\hline
\end{tabular}

M (músculo); DA (fibras anteriores do músculo deltóide); PM (peitoral maior); BB (bíceps braquial), TB (tríceps braquial); TS (fibras superiores do músculo trapézio); SA (serrátil anterior); DP (deltóide posterior). 


\subsection{Força produzida durante os exercícios wall-press, bench-press e push-up} nos dois níveis de esforço isométrico

Os valores de carga obtidos durante os exercícios estão na Tabela 8. Os maiores valores de carga foram obtidos no exercício bench-press, nos dois níveis de esforço isométrico. Os valores intermediários de carga foram alcançados durante o push-up e os menores valores de carga foram obtidos durante o exercício wall-press, também nos dois níveis de esforço isométrico.

Tabela 8. Valores médios e desvio-padrão dos valores de carga obtidos durante os exercícios $(n=20)$

\begin{tabular}{cccc}
\hline & Wall-press & Bench-press & Push-up \\
\hline $\mathbf{1 0 0} \%$ Esforço I sométrico Máximo & $7.5 \pm 0.12 \mathrm{kgf}$ & $46.6 \pm 0.60 \mathrm{kgf}$ & $31.3 \pm 0.26 \mathrm{kgf}$ \\
$\mathbf{8 0} \%$ Esforço I sométrico Máximo & $6.0 \pm 0.07 \mathrm{kgf}$ & $36.4 \pm 0.47 \mathrm{kgf}$ & $25.8 \pm 0.32 \mathrm{kgf}$ \\
\hline
\end{tabular}

Kgf (quilograma-força) 
"Ninguém está mais sujeito a cometer mais erros do que aquele que age baseado apenas no seu pensamento"

Marques de Vauvenargues

\section{Discussão}




\section{Discussão}

Os resultados do presente estudo demonstraram que não houve uma semelhança nos valores de RMS normalizados dos músculos avaliados nas comparações feitas entre os três exercícios, embora eles fossem biomecanicamente semelhantes, não confirmando a hipótese inicial deste trabalho. Também foi verificado que os dois níveis de esforços isométricos utilizados durante os exercícios não foram capazes de influenciar a resposta eletromiográfica.

Oliveira, Carvalho e De Brum (2006) e Oliveira et al. (2006) também encontraram diferentes níveis de atividade eletromiográfica entre exercícios biomecanicamente comparáveis e estes autores relatam que, apesar da similaridade biomecânica entre os exercícios, a diferença entre os valores eletromiográficos pode estar relacionada à quantidade de esforço isométrico (OLIVEIRA; CARVALHO; DE BRUM, 2006) e a certas características dos exercícios, como a co-ativação promovida pela carga axial, que podem ter favorecido a ativação de um músculo em relação a outro (OLIVEIRA et al., 2006). Os resultados do presente estudo, por outro lado, discordam de Dillman et al. (1994) e Blackard, Jensen e Ebben (1999), que demonstraram que exercícios biomecanicamente semelhantes promovem níveis de atividade eletromiográfica semelhante em músculos motores primários.

No entanto, durante os estudos de Dillman, Murray e Hintermeister (1994) e de Blackard, Jensen e Ebben (1999), os voluntários realizaram os exercícios com carga axial em contração dinâmica e com cargas de igual valor e não com porcentagem de carga relativa ao esforço isométrico máximo, o que tornaria as comparações mais fidedignas.

Apesar das diferenças nas amplitudes eletromiográficas em exercícios com carga axial serem dependentes da intensidade desta carga, estudos têm avaliado esta variável a partir de exercícios realizados com mesmo valor de carga (DILLMAN et al., 1994; BLACKARD; JENSEN; EBBEN, 1999) ou de esforço isométrico (OLIVEIRA; CARVALHO; DE BRUM, 2004; OLIVEIRA et al., 2006). Diferentemente destas 
pesquisas, o presente estudo optou pela escolha de um valor de esforço isométrico e pela padronização desses valores para cada exercício.

Ao observarmos a postura e os movimentos realizados pelo corpo humano, notamos que a musculatura atua em conjunto para a manutenção destes posicionamentos e é influenciada pela posição do segmento corporal em relação à gravidade, pela resistência aplicada e pela velocidade do movimento não sendo, portanto, resultado de uma ação muscular isolada. Dessa forma, nos movimentos em cadeia cinética fechada todos os músculos do segmento podem estar ativos para produzir um movimento desejado, conter um movimento indesejável ou para estabilizar uma articulação (SMITH; WEISS; LEHMKUHL, 1997).

Dessa forma, apesar do objetivo inicial do trabalho não ter sido analisar a atuação dos pares de força do complexo articular do ombro, é importante considerar que a estabilidade dinâmica deste complexo durante os movimentos de elevação do braço é decorrente da ação conjunta entre estes pares de força. O par de forças deltóide-manguito rotator produz uma ação muscular agonista/antagonista que diminui as forças de cisalhamento geradas pela ação do deltóide, causando uma compressão da cabeça umeral na cavidade glenóidea, fornecendo equilíbrio dinâmico à articulação glenoumeral em qualquer posição do braço (WILK; ARRIGO; ANDREWS, 1997; EKSTRON; SODERBERG; DONATELLI, 2004; REINOLD et al., 2004). As fibras superiores do trapézio e o serrátil anterior constituem o par de forças que atuam na articulação escapulotorácica, produzindo rotação superior da escápula durante os movimentos do braço, mantendo uma adequada relação comprimento-tensão dos músculos que atuam no úmero e tem uma importante função estabilizadora nesta articulação (INMAN; SAUNDERS; ABBOTT, 1944; KANKAR; IRRGANG; WHITNEY, 1993; WILK; ARRIGO; ANDREWS, 1997). Considerações sobre o par de forças deltóide-manguito rotador não poderão ser feitas, visto que a atividade elétrica do manguito rotator não foi avaliada nesta pesquisa. Entretanto, serão feitas considerações sobre o par de forças trapézio serrátil anterior. 
Durante a análise eletromiográfica do serrátil anterior e das fibras superiores do trapézio nos três exercícios estudados nesta pesquisa, verificamos que não houve um aumentou ou uma diminuição simultânea e significativa da atividade eletromiográfica destes músculos, ou seja, no par de forças serrátil-trapézio, mas foram observadas alterações significativas destes músculos isoladamente. Uma provável explicação para estes achados é a diferença de posicionamento entre os exercícios. O wall-press possui um componente de carga rotacional, ausente no exercício push-up e bench-press, o que justificaria a maior atividade elétrica das fibras superiores do músculo trapézio, necessária para manter a rotação superior da escápula, evidenciando a necessidade de se avaliar a direção da carga, se rotacional ou axial durante os exercícios (LEPHART; HENRY, 1996). Já o bench-press possui uma grande estabilidade da escápula garantida pelo posicionamento e pelo peso corporal, mantendo-a mais estável junto ao gradil costal, tornando-a menos dependente da ação do músculo serrátil anterior e da porção superior do músculo trapézio em relação aos demais exercícios.

A não diferença estatisticamente significativa da atividade elétrica do músculo serrátil anterior entre os exercícios wall-press e push-up pode ser justificada pelo apoio unilateral, que tornou estes dois exercícios mais instáveis em relação ao benchpress. Além disso, à ausência do movimento de protração escapular nestes exercícios pode ter causado menor atividade do serrátil anterior, visto que a literatura tem demonstrado que os exercícios que envolvem a protração e/ou rotação superior escapular são responsáveis pelo maior nível de atividade eletromiográfica do músculo serrátil anterior (MOSELEY et al., 1992; LUDEWIG; COOK; NAWOCZENSKI, 1996; LEAR; GROSS, 1998; DECKER et al., 1999; EKSTROM et al., 2003).

Já o bench-press possui uma estabilidade escapular garantida pelo posicionamento e pelo peso corporal, mantendo-a mais estável junto ao gradil costal, tornando-a menos dependente da ação do músculo serrátil anterior e da porção superior do músculo trapézio em relação aos demais exercícios. Entretanto, o apoio bilateral da cintura escapular, associado à estabilidade do posicionamento pode ter 
favorecido a atividade do serrátil anterior, proporcionando um maior torque isométrico de protração escapular, apesar deste movimento ter sido limitado. Além disso, a maior estabilidade neste exercício pode ter causado uma diminuição da atividade da musculatura sinergista do membro superior avaliado (fibras médias e inferiores do trapézio, rombóides e elevador da escápula) e da cintura escapular contralateral em relação aos demais exercícios que, associado a um possível aumento de torque na articulação escapulotorácica, favoreceu a atividade eletromiográfica do serrátil anterior.

Estes achados evidenciam a necessidade de se avaliar a musculatura estabilizadora sinergista da escápula em exercícios para extremidade superior, incluindo movimentos não considerados nesta pesquisa, como a protração, retração e rotação superior da escápula. Além disso, durante os exercícios wall-press e push-up, o músculo serrátil anterior contralateral ao membro avaliado pode ter atuado de maneira significativa durante os exercícios para manter a estabilidade da cintura escapular e o posicionamento do exercício, diminuindo a necessidade da ação do serrátil do membro dominante.

Apesar dos valores de esforço isométrico avaliados no presente estudo não terem sido capazes de produzir diferença na atividade eletromiográfica do par de força trapézio-serrátil e durante a comparação do mesmo exercício nos dois níveis de esforço, eles foram capazes de alterar as características de ativação da musculatura avaliada entre os exercícios, possivelmente ocasionadas pelas diferentes representações de $100 \%$ e $80 \%$ de esforço máximo que o voluntário foi capaz de realizar durante os exercícios sem que saísse do posicionamento padrão. A causa desta diferença pode estar relacionada ao fato de que os exercícios propostos nesta pesquisa possuem características próprias que diferenciam a capacidade de gerar força e, conseqüentemente, alteram a atividade eletromiográfica.

No exercício wall-press, o valor médio de força registrado foi de $7,5 \pm 0,12 \mathrm{kgf}$, menor que os valores médios encontrados para os exercícios push-up e bench-press. Essa menor produção de força pode ter sido ocasionada pela posição ortostática do 
voluntário durante o exercício e a falta de um apoio dorsal fixo que dificultaram o emprego de um esforço maior contra uma base de apoio, pois um aumento na força levaria o voluntário a protrair a escápula, causando alteração na postura padrão para a realização do exercício.

No push-up, o aumento do esforço isométrico contra a base de apoio poderia causar as mesmas alterações na articulação escapulotorácica que no wall-press e, além disso, o posicionamento do voluntário neste exercício impede a produção de uma força menor do que a necessária para sustentação do próprio peso corporal, influenciando a quantidade de esforço necessária para a execução do exercício. A força média registrada durante o push-up foi de $31,3 \pm 0,26 \mathrm{kgf}$. É importante ressaltar que não foi possível comparar outros valores de esforço isométrico máximo nesta pesquisa porque apenas o posicionamento do voluntário para a realização do exercício push-up, em geral, ocasionava aproximadamente $75 \%$ do esforço máximo.

Situação diferente foi encontrada no bench-press, em que o posicionamento do voluntário permitiu uma maior produção de força, provavelmente em conseqüência do apoio dorsal fixo, que gerou maior estabilidade e, possivelmente, maior facilidade em

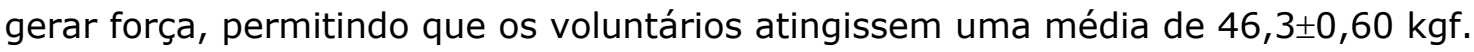

Estudos sobre fadiga muscular têm demonstrado que a ativação entre músculos sinergistas possui um recrutamento assincrônico durante baixos níveis de contração muscular, porém, quando os níveis de contração aumentam, esse recrutamento não é evidente (GRITTI; SCHIEPPATI, 1989; SCHIEPPATI; ROMANO; GRITTI, 1990; FALLENTIN; JORGENSEN; SIMONSEN, 1993; KOUZAKI et al., 2002). Gritti e Schieppati (1989) e Schieppati, Romano e Gritti (1990) sugeriram que o recrutamento assincrônico de unidades motoras durante a atividade sinergista em contrações realizadas em níveis máximos e submáximos de contração está relacionada ao equilíbrio entre aferências periféricas em movimentos voluntários. Ainda que o tempo de contração muscular do presente estudo não tenha sido suficiente para causar fadiga muscular, a ausência de similaridade eletromiográfica pode ter sido decorrente da proximidade entre os valores de esforço isométrico, pois o mecanismo 
que o sistema nervoso central utiliza em contrações de fadiga durante esforço elevado pode ter sido o mesmo, o que pode não ter causado diferenças na amplitude eletromiográfica.

Durante a realização do exercício wall-press, os resultados deste estudo encontraram uma menor atividade eletromiográfica das fibras anteriores do músculo deltóide e do peitoral maior durante a realização do exercício wall-press com apoio unilateral que a encontrada por Dillman, Murray e Hintermeister (1994). Em relação ao bench-press e ao push-up, os resultados também diferem dos achados de Dillman, Murray e Hintermeister (1994), que encontraram maiores atividades eletromiográficas para as fibras anteriores do músculo deltóide e peitoral maior quando comparadas às obtidas no bench-press e menor atividade eletromiográfica das fibras posteriores do músculo deltóide e do peitoral e similaridade eletromiográfica das fibras anteriores do músculo deltóide durante o push-up.

Os resultados do presente estudo diferem dos encontrados por Blackard, Jensen e Ebben (1999), pois foi observada uma maior atividade eletromiográfica da cabeça longa do músculo tríceps braquial durante os exercícios bench-press e pushup, enquanto a porção clavicular do músculo peitoral maior teve menor atividade eletromiográfica durante o bench-press e maior atividade eletromiográfica durante o push-up. Entretanto, estes autores realizaram os exercícios com mesmo valor de carga e não em valores relativos ao esforço isométrico máximo, o que pode ter contribuído para a divergência dos resultados. Além disso, os trabalhos de Dillman et al. (1994) e Blackard, Jensen e Ebben (1999), avaliaram exercícios em contrações dinâmicas, outro fator que pode causar maiores variações do sinal eletromiográfico quando comparado com contrações isométricas (DE LUCA, 1997). Embora o registro dinâmico seja mais interessante por ser mais próximo à aplicação clínica e as atividades de vida diária, variações no comprimento muscular, na velocidade ou no tipo de contração e a mudança do número de unidades motora sob o sítio de aquisição do eletrodo torna sua aquisição mais vulnerável (DE LUCA, 1997). 
Os resultados do presente estudo, referentes ao exercício push-up, revelaram atividade eletromiográfica semelhante para as fibras posteriores do músculo deltóide, para as fibras superiores do músculo trapézio e para o serrátil anterior e maior atividade eletromiográfica das fibras anteriores do músculo deltóide quando comparadas aos resultados obtidos por Decker et al. (1999) durante knee push-up. Porém, maiores valores de amplitude eletromiográfica do músculo serrátil anterior e das fibras superiores do músculo trapézio foram encontradas nas pesquisas de Lear e Gross (1998) e de Ludewig et al. (2004). Entretanto, Lear e Gross (1998) e Ludewig et al. (2004) realizaram o exercício push-up com apoio nos pés enquanto Decker et al. (1999) realizaram o knee push-up, o que poderia ser justificar as diferenças entre os estudos.

Ao compararmos os resultados obtidos neste estudo durante o exercício pushup aos resultados obtidos por Uhl et al. (2003) durante o tripod position, observamos valores semelhantes de atividade eletromiográfica para as fibras anteriores do músculo deltóide e menores valores eletromiográficos para as fibras posteriores do músculo deltóide e peitoral maior. Assim como no estudo de Uhl et al. (2003), ao analisarmos os valores de atividade eletromiográfica das fibras posteriores do músculo deltóide obtida no presente estudo observa-se que este músculo atingiu os maiores valores de atividade eletromiográfica normalizado quando comparados aos demais músculos avaliados. Uhl et al (2003) justificam essa maior atividade das fibras posteriores do músculo deltóide como necessária para prevenir a excessiva queda do ombro contralateral, com o objetivo de manter o tronco paralelo ao solo.

A atividade eletromiográfica do músculo peitoral maior e da cabeça longa do músculo tríceps braquial obtida nas pesquisas de Cogley et al. (2005) e Gouvali e Boudolos (2005) durante a realização de variações do exercício push-up, entre eles o push-up padrão foram maiores que as encontradas no presente estudo. Essas diferenças podem ter sido causadas pela realização dos exercícios de forma dinâmica e com apoio bilateral, diferentemente desta pesquisa que realizou os exercícios com apoio unilateral e em isometria. Outro motivo que pode ter causado diferenças entre 
os resultados é que a atividade eletromiográfica destes dois estudos foi analisada em valores de root means square (RMS) e não por valores de integral da envoltória do registro eletromiográfico, sugerido pelas recomendações do Projeto SENIAN (HERMENS et al., 1999) como melhor análise de amplitude eletromiográfica para contrações dinâmicas.

Ao compararmos os dados da atividade eletromiográfica obtida na pesquisa de Lehman (2005) durante o exercício bench-press realizado a 100\% da distância biacromial, $90^{\circ}$ de flexão de ombro e em posição pronada do antebraço, que se assemelha ao bench-press desta pesquisa, observamos que a atividade do peitoral maior e da cabeça longa do músculo bíceps braquial foram maiores que os encontrados no presente estudo. A realização dos exercícios de maneira dinâmica e com apoio bilateral durante a pesquisa de Lehman (2005) podem ter causado variações entre os resultados, porque este posicionamento pode levar a uma maior descarga de peso sobre os membros.

Barnett; Kippers e Turner (2005) estudaram a atividade eletromiográfica da cabeça longa do músculo tríceps braquial, das fibras anteriores do músculo deltóide e do peitoral maior no flat bench-press (horizontal) e o vertical bench-press, que se assemelham, respectivamente, ao bench-press e ao wall-press desta pesquisa. Em relação ao flat bench-press, estes autores encontraram valores de atividade eletromiográfica próximos a 0,5 mV.s para a porção clavicular do peitoral maior, próximos a 0,7 mV.s para as fibras anteriores do músculo deltóide e próximos a 0,72 mV.s para a cabeça longa do tríceps braquial. Os resultados do vertical bench-press evidenciaram valores próximos a 0,3 mV.s para a porção clavicular do peitoral maior, próximos a 0,9 mV.s para as fibras anteriores do músculo deltóide e próximos a 0,45 mV.s para a cabeça longa do tríceps braquial

Welsch; Bird e Mayhew (2005) analisaram a atividade eletromiográfica das fibras anteriores do músculo deltóide e do peitoral maior em variações do exercício bench-press e, entre eles, o dumbbell bench-press, que se assemelha ao bench-press dessa pesquisa. Estes pesquisadores encontraram atividade eletromiográfica de 
$78,5 \pm 17,5$ mV.s para o músculo peitoral maior e de $85,3 \pm 10,5 \mathrm{mV} . \mathrm{s}$ para as fibras anteriores do músculo deltóide.

Porém, os resultados obtidos por Barnett, Kippers e Turner (2005) e por Welsch, Bird e Mayhew (2005) não podem ser comparados aos desta pesquisa de maneira fidedigna porque foram analisados em millivolt.segundo, ou seja, não foram normalizados. Se comparações de atividade eletromiográfica são feitas entre músculos, dias, sujeitos ou estudos, o procedimento de normalização é recomendado para que os resultados possam ser comparados com dados similares de outros estudos (SODERBERG, KNUTSON, 2000).

Ao compararmos os resultados do presente estudo com os obtidos na pesquisa de Oliveira et al. (2006), observamos diferenças que podem estar relacionadas ao procedimento experimental, à análise dos dados e ao sexo da amostra, visto que o exercício wall-press destes pesquisadores foi realizado no plano da escápula, o procedimento de normalização foi feito pelo valor médio de três CIVMs e a amostra era feminina. Em relação aos exercícios wall-press e bench-press, os resultados desta pesquisa demonstraram menores valores de atividade eletromiográfica para os músculos peitoral maior, bíceps e tríceps braquial, fibras superiores do músculo trapézio e fibras anteriores do músculo deltóide. O posicionamento do membro superior no plano da escápula durante o exercício wall-press proporcionou uma relação comprimento-tensão nos músculos avaliados diferente da relação comprimento-tensão no wall-press feito no plano sagital, causando uma variação no número de unidades motoras sob o sítio de detecção dos eletrodos, justificando as diferenças dos resultados encontrados entre os trabalhos. Outra fonte de divergência nos resultados pode ter sido o procedimento de normalização, pois o presente estudo normalizou os dados brutos pelo valor máximo obtido de três contrações isométricas voluntárias máximas.

Em relação ao exercício bench-press, apesar dos valores eletromiográficos terem sido maiores no trabalho de Oliveira et al (2006), houve uma semelhança no padrão de distribuição de atividade eletromiográfica, visto que os dois estudos 
resultaram em uma maior atividade eletromiográfica do músculo tríceps braquial, seguido de uma maior atividade das fibras anteriores do músculo deltóide, do peitoral maior, das fibras superiores do músculo trapézio e do bíceps braquial. Cogley (2005) observaram uma maior atividade eletromiográfica, apesar de não ser estatisticamente significativa, em mulheres quando comparada aos homens durante a realização do exercício bench-press, o que pode ter causado as diferenças entre os resultados, pois a amostra do presente estudo era masculina e da pesquisa de Oliveira et al. (2006), feminina.

Os exercícios wall-press, bench-press e push-up em esforço isométrico máximo e apoio unilateral também foram estudados por Oliveira, Carvalho e De Brum (2006), cujos resultados mostram maior atividade eletromiográfica das fibras anteriores do músculo deltóide, do peitoral maior, das fibras superiores do músculo trapézio e do músculo serrátil anterior em todos os exercícios em relação aos valores encontrados neste estudo, com exceção da cabeça longa do músculo tríceps braquial, que apresentou menores valores de atividade eletromiográfica. Durante os exercícios bench-press e push-up, como na pesquisa de Oliveira et al. (2006), houve uma semelhança dos valores eletromiográficos, pois quando comparamos os valores de RMS normalizados, vimos que os músculos possuem a mesma ordem crescente de padrão de distribuição de atividade eletromiográfica dos músculos avaliados nos dois estudos.

Oliveira, Carvalho e De Brum (2006) e Oliveira et al. (2006) analisaram a atividade eletromiográfica durante esforço isométrico máximo e carga axial sem feedback sonoro e encontraram valores maiores de atividade eletromiográfica para a maioria dos músculos avaliados quando comparados aos do presente estudo. A utilização de um feedback sonoro pode ter causado as diferenças entre os resultados, pois sua utilização assegura que o nível de esforço isométrico foi mantido durante todo o registro do sinal eletromiográfico, com uma margem de erro de no máximo $10 \%$ da força pré-estabelecida. 
Os diferentes níveis de atividade eletromiográfica dos músculos avaliados durante os exercícios propostos nesta pesquisa sugere que cada exercício pode ser empregado em diferentes estágios de reabilitação, dependendo da condição do complexo articular do ombro que o paciente possui, do músculo ou grupo muscular a ser tratado e da fase do programa de reabilitação, pois o nível de atividade eletromiográfica, o nível de esforço gerado em cada exercício e a postura necessária para realizar um exercício são fatores a serem considerados nos diferentes estágios de reabilitação, além da classificação do exercício.

A análise de quanto um determinado exercício é capaz de ativar um músculo ou um grupo muscular auxilia a compreensão clínica em relação ao grau de ativação da musculatura envolvida, o que torna mais clara a escolha de exercícios para um programa de reabilitação (UHL et al., 2003). Os resultados do presente estudo demonstram que os níveis de atividade eletromiográfica normalizados obtidos durante os exercícios avaliados tiveram uma variação de $3 \%$ a $47 \%$ do valor de amplitude da contração isométrica voluntária máxima obtida em prova de função muscular. Lehman et al. (2006) também encontraram para o exercício push-up feito em base estável, valores de amplitude eletromiográfica considerados baixos para produzir aumento de força muscular, atribuindo seus resultados ao fato da amostra da sua pesquisa ser de voluntários atletas. Entretanto, os resultados do presente estudo são referentes a uma amostra de voluntários sedentários, não concordando com a consideração feita por Lehman et al. (2006) de que uma amostra com menor treinamento físico poderia atingir níveis de ativação capazes de gerar força muscular.

Os resultados do presente estudo, baseados na classificação de Di Giovine (1992), demonstraram atividade moderada (20\%-40\% da CIVM) para a porção anterior do músculo deltóide e peitoral maior a $100 \%$ do esforço isométrico máximo e do serrátil anterior a $100 \%$ e a $80 \%$ do esforço isométrico máximo no exercício wallpress. Durante o bench-press, alta atividade ( $41 \%-60 \%$ da CIVM) foi obtida para a cabeça longa do músculo tríceps braquial e do serrátil anterior e atividade moderada para a porção anterior do músculo deltóide e para o peitoral maior a $100 \%$ do esforço 
isométrico máximo. Em $80 \%$ do esforço isomérico máximo, este exercício ativou moderadamente a cabeça longa do músculo tríceps braquial e o serrátil anterior. Atividade moderada da cabeça longa do músculo tríceps braquial e do serrátil anterior foi encontrada nos dois valores de esforço isométrico máximo durante o push-up.

Embora exercícios com sustentação de peso sejam empregados em programas de reabilitação, poucas informações existem sobre a demanda imposta no ombro durante estes exercícios (UHL et al., 2003). Sendo assim, a carga imposta durante os exercícios em associação com a atividade eletromiográfica gerada é importante sob o ponto de vista clínico, pois facilita a inclusão de exercícios em diferentes fases de um programa de reabilitação. Em relação aos achados deste estudo, o wall-press seria um exercício indicado em fases precoces de reabilitação por gerar menores valores de carga e por ativar a musculatura em níveis consideráveis, ao passo que o bench-press seria indicado em fases finais ou posteriores ao emprego do wall-press, pois maiores cargas e valores de atividade eletromiográfica foram obtidas durante este exercício. $\mathrm{O}$ push-up, apesar de gerar uma carga maior em relação ao wall-press, a atividade eletromiográfica obtida foi menor para a maioria dos músculos avaliados. Estes achados, associados a uma maior dificuldade de posicionamento do voluntário durante a sua realização favorecem a escolha clínica do wall-press.

Em relação à discussão existente sobre as terminologias empregadas para classificar os exercícios para a extremidade superior, observamos inúmeros fatores que podem influenciar a atividade muscular durante um exercício (LEPHART; HENRY, 1996; BLACKARD; JENSEN; EBBEN, 1999) e podemos notar que uma terminologia talvez não consiga classificar os exercícios em poucas categorias, pois os fatores fisiológicos que interferem em um determinado exercício podem não interferir em outro, o que poderia gerar uma classificação extensa (DI FÁBIO, 1999). Dessa forma, a tentativa de definir melhor uma classificação dos exercícios para o membro superior pode acabar criando outros "jargões" além dos tão empregados "cadeia cinética aberta" e "cadeia cinética fechada" (DI FÁBIO, 1999). 
Desse modo, os resultados deste estudo concordam com Di Fábio (1999) e com Harbst e Wilder (2000), pois ao definirmos um exercício através de suas ações biomecânicas e neuromusculares, incluindo o número de articulações recrutadas, a magnitude e direção da carga, a ação neuromuscular e a especificidade do treinamento é possível fornecer uma descrição mais detalhada do exercício, do que apenas classificá-lo em uma determinada categoria. 
"Mesmo se eu soubesse que amanhã o mundo se partiria em pedaços, eu ainda plantaria a minha macieira"

Martin Luther King J r.

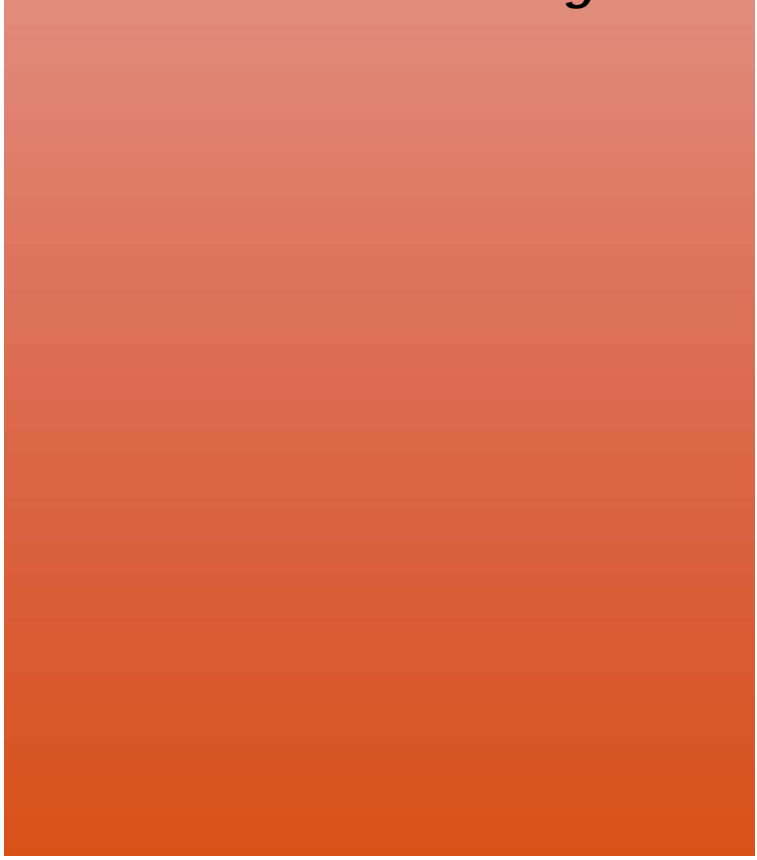

\section{Conclusão}




\section{Conclusão}

Através dos resultados obtidos nestas condições experimentais, obtivemos as seguintes conclusões:

- Os resultados evidenciaram que os valores de carga analisados neste estudo podem não ter sido suficientes para interferir nos valores obtidos das comparações feitas entre o mesmo exercício nos diferentes níveis de carga. Também evidenciaram que exercícios biomecanicamente comparáveis não necessariamente produzem atividade eletromiográfica semelhante quando comparados entre si, mesmo controlando a carga aplicada.

- Em relação ao esforço gerado, o bench-press foi o exercício em que os voluntários realizaram maior esforço isométrico e o wall-press o que eles realizaram o menor esforço isométrico. Apesar do objetivo deste trabalho não ter sido fazer uma relação EMG-força, podemos observar que o bench-press, quando comparado aos demais exercícios, gerou maiores níveis de atividade eletromiográfica para a maioria dos músculos estudados, possivelmente causada pelo maior esforço isométrico realizado. Apesar do esforço isométrico gerado no exercício wall-press ser menor que o realizado no push-up, a maioria dos músculos avaliados tiveram maior atividade eletromiográfica no wall-press, que pode ter sido ocasionada pela diferença do posicionamento do voluntário durante a realização do exercício.

- O wall-press é indicado em fases precoces de reabilitação por gerar atividade eletromiográfica considerável em um menor valor de esforço isométrico, enquanto que o bench-press é mais indicado em fases tardias do programa de reabilitação, por promover maiores valores de esforço isométrico e de atividade eletromiográfica quando comparado aos demais exercícios. 
“No Egito, as bibliotecas eram chamadas "tesouros dos remédios da alma". De fato, nelas curava-se a ignorância, a mais perigosa das enfermidades e origem de todas as outras"

Jacques - Bénigne Bossuet

\section{Referências Bibliográficas}




\section{Referências Bibliográficas}

1. ALKNER, B. A., TESCH, P. A.; BERG, H. E. Quadriceps RMG/force relationship in knee extension and leg press. Med Sci Sports Exerc., n. 32, p. 459-463, 2000.

2. BABAULT, N.; POUSSON, M.; MICHAUT, A.; VAN HOECKE, J. Effect of quadriceps femoris muscle length on neural activation during isometric and concentric contractions. J Appl Physiol., n. 94, p.983-990, 2003.

3. BARNETT, C.; KIPPERS, V.; TURNER, P. Effects of Variations of the Bench Press Exercise on the EMG Activity of Five Shoulder Muscles. J Strength Cond Res., n. 9, v. 4, p.222-227, 1995.

4. BASMAJIAN, J. V.; DE LUCA, C. J. Muscle Alive: Their functions revealed by electromyography. 5a Edição. Baltimore: William \& Wilkins, 1985.

5. BECKER, R.; AWISZUS, F. Physiological alteratios of maximal voluntary quadriceps activation by changes of knee joint angle. Muscle \& Nerve, n. 24, p.67-672, 2001.

6. BIGLAND-RITCHIE, B. R.; FURBUSH, F. H.; GANDEVIA, S. C.; THOMAS, C. K. Voluntary discharge frequencies of human motoneurons at different muscle lengths. Muscle \& Nerve, n. 15, p. 130-137, 1992.

7. BLACKARD, D. O.; JENSEN, R. L.; EBBEN, W. P. Use of the EMG analysis in challenging kinetic chain terminology. Med Sci Sports Exerc., n. 31, v. 3, p. 443-448, 1999.

8. CLARK, M. A.; FATER, D.; REUTEMAN. Core (Trunk) Stabilization and Its Importance for Closed Kinetic Chain Reabilitation. Orthop Phys Ther Clin North Am., n. 2, v. 9, p. 103-105, 2000.

9. COGLEY, R. M.; ARCHAMBAULT, T. A.; FIBEGER, J. F.; KOVERMAN, M. M.; YOUDAS, J. W.; HOLLMAN, J. H. Comparison of muscle activation using various hand positions during the push-up exercise. J Strength Cond Res., n. 19, v. 3, p.628-633, Ago, 2005.

10. DAVIES, C. J. Functional Progression of a Patient Through a Rehabilitation Program. Orthop Phys Ther Clin North Am., n. 2, v. 9, p. 103-105, 2000.

11. DE LUCA, C. J. The use of electromyography in biomechanics. J Biomech., n. 13, p. $135-163,1997$.

12. DECKER, M. J.; HINTERMEISTER, R. A.; FABER, K. J.; HAWKINS, R. J. Serratus Anterior Muscle Activity During Select Rehabilitation Exercises. Am J Sports Med., n. 27, p.784-791, 1999.

13. DI FÁBIO, R. P. Making jargon from kinetic and kinematic chains. J Orthop Sports Phys Ther., n. 29, v. 3, p. 142-143, Mar, 1999. 
14. DI GIOVINE, N. M.; JOBE, F. W.; PINK, M.; PERRY, J. An electromyographic analysis of the upper extremity in pitching. J Shoulder Elb Surg., n. 1, p. 1525, 1992

15. DILLMAN, C. J.; MURRAY, T. A.; HINTERMEISTER, R. A. Biomechanical differences of open and closed chain exercise with respect to the shoulder. J Sports Rehabil., n. 3, p. 228-238, 1994.

16. EKSTROM, R. A.; DONATELLI, R. A.; SODEBERG, G. L. Surface electromyographic analysis of exercises for the trapezius and serratus anterior muscles. J Orthop Sports Phys Ther., n. 33, p.33:247-57, 2003.

17. FALLENTIN, N.; JORGERSEN, K.; SIMONSEN, E. B. Motor unit recruitment durinc prolonged isometric contractions. Eur J Appl Physiol Occup Physiol., n.67, v.4, p.335-41, 1993.

18. FARINA, D.; MERLETTI, R.; ENOKA, R. M. The extraction of neural strategies from the surface EMG. J Appl Physiol., n. 96, p. 1486-1495, 2004.

19. GOUVALI, M. K.; BODOULOS, K. Dynamic and electromyographical analysis in variants of push-up exercise. J Strength Cond Res., n. 19, v. 1, p. 146-151, Fev, 2005.

20. GRAY, G. W.; PETERSON, J.; BRYANT C. Plane Sense. Fitness Manage. n. 8, p 31-33, 1992

21. GRITTI, I.; SCHIEEPPATI, M. Short-latency inhibition of soleus motoneurones by impulses in Ia afferents from the gastrocnemius muscle in humans. J Physiol., $\mathrm{n}$ 416, p. 469-84, Sep, 1989.

22. HARBST, K. B.; WILDER, P. A. Neurophysiology, Motor Control and Learning Basis of Closed Kinetic Chain Exercise. Orthop Phys Ther Clin North America., n. 2 , v. 9, p. 137-149, 2000.

23. HECKATHORNE, C. W.; CHILDRESS, D. S. Relationships of the surfaceelectromyogram to the force, length, velocity, and conduction rate of the cineplastic human biceps. Am J Sports Med., n. 60, p. 1-19, 1981.

24. HENNEMAN, E.; SOMJEN, G.; CARPENTER, D. O. Functional significance of cell size in spinal Motoneurons. J Neurophysiol., n. 28, p.560-80, 1965.

25. HERMENS, H. J.; FRERIKS, B.; STEGMAN, D.; BLOCK, J.; RAU, G, DISSLHORSTKLUG; HÄGG, G. European Recommendations for Surface Electromyography - Results of the SENIAN Project. Enschede, The Netherlandes: Roessingh Research and Development, 1999.

26. HINTERMEISTER, R. A.; LANGE, G. W.; SCHULTHEIS, J. M.; BEY, M. J.; RAWKINS, R. J. Electromyographic activity and applied load during shoulder rehabilitation exercises using elastic resistance. Am J Sports Med., n. 26, p. 210- 220, 1998. 
27. INMAN, V. T.; SAUNDERS, J. B. M.; ABBOTT, L. C. Observations on the function of the shoulder joint. J Bone J oint Surg., n. 26, v. 1, p. 1-30, 1944.

28. KANKAR A.; Irrgang, J. J.; Whitney, S. L. Nonoperative management of Secundary Shoulder Impigement Syndrome. J Orthop Sposrts Phys Ther., n. 17, v. 5, p. $212-$ 224, 1993.

29. KELLY, B. T.; KIRKENDALL, D. T.; LEVY, A. S.; SPEER, K. P. Current research or Muscle activity about the Shoulder. Instr. Cours Lect., n. 4, p. 4:53-66, 1997.

30. KENDALL, F. P.; MCCREARY, E. K.; PROVANCE, P. G. Músculos - Provas $\epsilon$ Funções. 4a Edição. São Paulo-SP: Editora Manole LTDA, p. 235-298, 1995.

31. KENNEDY, P. M.; CRESSWELL, A. G. The effect of muscle length on motor unit recruitment during isometric plantar flexion in humans. Exp Brain Res., n. 137, p. $258-264,2001$.

32. KIBLER, B.; LIVINGSTON, W.; BRUCE, R. Current concepts in shoulder rehabilitation. Adv Oper Orthop., n.3, p. 249-299, 1995.

33. KIBLER, B.; LIVINGSTON, W. Closed-Chain Rehabilitation for Upper and Lowe Extremities. J Am Acad Orthop Surg., n. 9, p. 412-421, 2001.

34. KOUZAKI, M.; SHINOARA, M.; MASQANI, K.; KANEHISA, H.; FUKUNAGA, T. Alternate muscle activity observed between knee extensor synergists during low. level sustained contractions. J Appl Physiol., n. 93. v. 2, p.675-84, 2002.

35. KRASPISIN, J. E.; GRABINER, M. D. Joint angle-dependence of elbow flexor activation levels during isometric and isokinetic maximum voluntary contractions.

Clin Biomech., n. 15, p. 743-749, 2000.

36. KUKULKA, C.G.; CLAMANN, P. Comparison of the recruitment and discharge propertiers of motor units in human braquial biceps and adductor pollicis during isometric contractions. Brain Res., n. 219, p. 45-55, 1981.

37. LAWRENCE, J. H.; DE LUCA, C. J. Myoelectric Signal vs Force Relationship in Different Human Muscle. J Applied Physiol., n. 54, p. 1653-1659, 1983.

38. LEAR, L. J.; GROSS, M. T. An Electromyographical Analysisof the Scapular StabilizingSynergists During aPush-up Progression. J OSPT,. n. 28, v. 3, p. 146157, 1998.

39. LEHMAN, G. J. The influence of grip width and forearm pronation/supination on upper-body myoelectric activity during the flat bench press. J Strenght Cond Res., n. 19, v. 3, p. 587-591, Ago, 2005.

40. LEHMAN, G. J.; MACMILLAN, B.; MACINTYRE, I.; CHIVERS, I.; FLUTER, M. Shoulder muscle EMG activity during push up variations on and off a Swiss ball. Dyn Med., n. 9, p. 1-7, Jun, 2006.

41. LEPHART, S. M.; HENRY, T. J. The Physiological Basis for Open and Closed Chain 
Rehabilitation for the Upper Extremity. J Sports Rehabil., n.5, p.71-87, 1996.

42. LITTELL, R. C.; MILLIKEN, G. A.; STROUP, W.W.; WOLFINGER, R. D. SAS System of Non-linear Mixed Models. Cary, NC: SAS Institute Inc, 1996.

43. LUDEWIG, P. M.; HOFF, M. S.; OSOWSKI, E. E.; MESCHKE, S. A.; RUNDQUIST, P. J. Relative Balance of serratus anterior and upper trapezius muscle activity during push-up exercises. Am J Sports Med., n.32, v. 2, p. 484-93, 2004.

44. MCDONAGH, M. J. N.; DAVIES, C. T. M. Adaptive response of mammalian skeletal muscle to exercise with high loads. Eur J Appl Physiol Occup Physiol., n. 52, p.139-55, 1984.

45. MCGEE, D. J. Avaliação Musculoesquelética. 4a Edição. São Paulo: Editora Manole, 2005.

46. MCLEAN, R. A.; SANDERS, W. L.; SROUP, W. W. A unified approach to mixed linear models. Am Statistic., n. 45; p. 54-64, 1991.

47. MOSELEY JUNIOR, J. B.; JOBE, F. W.; PINK, M.; PERRY, J.; TIBONE, J. EMG analysis of the scapular muscles during a shoulder rehabilitation program. Am J Sports Med., n. 20, v. 2, p. 128-34, 1992.

48. NEWMAN, S. A.; JONES, G.; NEWHAM, D. J. Quadriceps voluntary activation at different joint angles measured by two stimulation techniques. Eur J Appl Physiol., n. 89, p. 49-499, 2003.

49. NOURBAKHSH, M. R.; KUKULKA, C. G. Relationship between muscle length and moment arm om EMG activity of human triceps surae muscle. J Electromyogr Kinesiol., n. 14, p. 263-273, 2004.

50. OliVEIRA, A. S.; FREITAS, C. M. S.; MONARETTI, F. H.; FERREIRA, F.; NOGUTi, R.; BÉRZIN, F. Avaliação eletromiográfica de músculos da cintura escapular e braço durante exercícios com carga axial e rotacional. RBME, n. 12, p. 1-5, 2006.

51. OliveirA, A. S.; CARVALHO, M. M.; DE BRUM, D. P. C. Activation of the shoulder and arm muscles during axial load exercises on a stable base of support and on a medicine ball. J Electromyogr Kinesiol., 2006 (accept; in press).

52. PANARIELLO, R. A. The closed kinetic chain in strength training. Natl Strenght Cond Assoc J ., n. 13, p. 29-33, 1991.

53. PASQUET, B.; CARPENTIER, A.; DUCHATEAU, J. Change in Muscle Fascicle Length Influences the Recruitment and Discharge Rate of Motor Units During isometric Contractions. J Neurophysiol., n. 94, p. 3126-3133, 2005.

54. PERRY, J.; BECKEY, G. A. EMG-force relationship in skeletal muscle. Crit Rev Biomed Eng., n. 7, v. 1, p 1-22, 1981. 
55. POLGAR, J.; JOHNSON, M. A.; WEIGHTMAN, D.; APPLETON. Data on fiber size in thirty-six human muscles: an autopsy study. J. Neurol. Sci., n. 19, p. 307-318, 1973.

56. RASSIER, D. E.; MACINTOSH, B. R.; HERZOG, W. Lenght dependence of active force production in skeletal muscle. J. Appll. Physiol., n. 86, v. 5, p. 14451457, 1999.

57. REINOLD, M. M.; WILK K. E.; FLEISIG; G. S.; ZHENG, N.; BARRENTINE S. W.; CHMIELEWSKI, T.; CODY, R. C.; JAMESON, G. G.; ANDREWS, J. R. Electromyographic Analysis of the Rotator Cuff and Deltoid Musculature During Common Shoulder External Rotation exercises. J Orthp Phys Ther., n.34, v. 7, p. 385-394, 2004.

58. RIVERA, J. Open Versus Closed Kinetic Chain Rehabilitation of the Lower Extremity: A Funcional and Biomechanical Analysis. J Sports Rehabil., n. 3, p. 154-167, 1994.

59. SCHALL, R. Estimulation in generalized linear models with random effects. Biometrika, n. 78, p. 719-727, 1991.

60. SCHIEPATI, M.; ROMANO, C.; GRITTI, I. Convergence of Ia fibres from synergistic and antagonistic muscles onto interneurones inhibitory to soleus in humans. J Physiol., n. 431, p. 365-77, Dec, 1990.

61. SMITH, L. A.; WEISS, E. L.; LEHMKUHL, L. D. Cinesiologia Clínica de Brunnstrom. 5a Edição. São Paulo-SP: Editora Manole LTDA, p. 259-297, 1997.

62. SODEBERG, G. L.; KNUTSON, L. M. A guide for use and interpretation of kinesiologic electromyographic data. Phys Ther., n. 80, p. 485-98, 2000.

63. SOLOMONOV, M.; BARATTA, R.; SHOJI, H.; D'AMBROSIA, R. Electromyogram power spectra frequencies associated with motor unit recruitment strategies. J Appl Physiol., n. 68, v. 3, p.1177-1185, 1990.

64. STEINDLER, A. Kinesiology of the Human Body Under Normal and Pathological Conditions. Springfield: Il. Charles C. Thomas, 1955.

65. STONE, J. A.; LUEKEN, J. S.; PARTIN, N. B.; TIMM, K. E.; RYAN, E. J. Closed kinetic chain rehabilitation for the glenoumeral joint. J Athl Training., n. 28, p. 28:34-37, 1993.

66. SUTER, E.; HERZOG, W. Extend of muscle inhibition as a function of knee angle. J Electromyogr Kinesiol., n.7, p. 123-130, 1997.

67. TAX, J. J.; VAN DER GOM, D.; GIELEN, C. C. A. M.; KLEYNE, M. Differences in central control of $\mathrm{m}$. biceps brachii in movment tasks and force tasks. Exp Brain Res., n.79, p. 138-142, 1990. 
68. UHL, T. L.; CARVER, T. J.; MATTACOLA, C. G.; MAIR, S. D.; NITZ, A. J. Shoulder musculature activation during upper extremity weight-bearing exercise. J Orthop Sports Phys Ther., n. 33, v. 3, p. 109-117, Mar, 2003.

69. VAN DER LINDEN, D. W.; KUKULKA, C. G.; SODERBERG, G. L. The effect of muscle length on motor unit discharge characteristics in human tibialis anterior muscle. Exp Brain Res., n. 84, p. 210-218, 1991.

70. WELSCH, E. A.; BIRD, M.; MAYHEW, J. L. Electromyographic activity of the pectoralis major and anterior deltoid muscles during three upper-body lifts. J Strength Cond Res., n. 19, v. 2, p. 449-452, May, 2005.

71. WILK, E. K.; ARRIGO, C. A.; ANDREWS, J. R. Closed and Open Kinetic Chain Exercise for the Upper Extremity. J Sports Rehabil., n. 5, p. 88-102, 1996.

72. WOODS, J. J.; BIGLAND-RITCHIE, B. linear and non-linear surface EMG/force relationships in human muscles. An anatomical/functional argument for the existence of both. Am J Phys., n. 62, v. 6, p. 287-299, 1983. 


\section{APÊNDI CE A - Testes Ortopédicos}

- Neer (teste irritativo para o manguito rotador): A mão esquerda fixa a escápula e mão direita eleva rapidamente o membro superior em flexão anterior (MAGEE, 2005).

- Hawkins (teste irritativo para o manguito rotador e avalia a força do supraespinhoso e infraespinhoso): O membro superior abduzido no plano escapular, rodado internamente $O$ paciente tenta realizar rotação externa enquanto o examinador faz força no sentido oposto (MAGEE, 2005).

- Jobe: teste que avalia o músculo supraespinhoso. Realizado de maneira comparativa com o lado oposto, o paciente abduz ativamente os braços no plano da escápula, em rotação interna e o examinador faz força em sentido oposto (MAGEE, 2005).

- Yergason: teste irritativo para o tendão da porção longa do bíceps braquial. O paciente deixa o braço aduzido, com o antebraço fletido a $90^{\circ} \mathrm{e}$ em posição neutra de prono-supinação. A resistência é feita no sentido da supinação do antebraço (MAGEE, 2005).

- Gerber: analisa a integridade do manguito rotador. $O$ paciente estende o braço em rotação interna e flexão de antebraço. A resistência é feita pelo examinador no sentido da rotação interna do ombro. A integridade muscular permite que o paciente tenha a capacidade de manter a mão afastada da região lombar (MAGEE, 2005).

- Rockwood: (analisa a instabilidade ântero-posterior da articulação glenoumeral) pinçando a cabeça umeral o examinador observa hiperelasticidade, instabilidade, e subluxação. (MAGEE, 2005).

- Do Sulco (para luxação inferior da cabeça do úmero) pinça a região da espinha da escápula e clavícula, e traciona com a outra mão a parte inferior do úmero para baixo (MAGEE, 2005).

- Teste de Estabilidade Ligamentar do Cotovelo: (empregado para analisar a integridade dos ligamentos colaterais medial e lateral do cotovelo). O braço do paciente fica com o antebraço levemente fletido e o terapeuta realiza uma força no sentido medial para analisar a integridade do ligamento colateral medial e vice-versa (MAGEE, 2005).

- Teste de Cozen: (avalia tendinite dos extensores do punho). O cotovelo do paciente é fletido e o punho estendido. É feita uma força no dorso do punho, no sentido da flexão (MAGEE, 2005).

- Teste de Epicondilite Medial: (avalia a presença de tendinite dos flexores do punho). O cotovelo e o punho do paciente são fletidos. É feita uma força no punho, no sentido da extensão (MAGEE, 2005).

- Teste de Phalen: avalia a presença de compressão do nervo mediano. Os punhos são fletidos de forma que dorso das mãos ficam em contato. Esta posição deve ser mantida durante 1 minuto e a ausência de dor e parestesia indicam ausência da doença (MAGEE, 2005). 


\section{APÊNDI CE B - TERMO DE CONCORDÂNCI A PARA OS PARTI CI PANTES DA \\ PESQUISA}

Consentimento formal de participação no estudo intitulado: "AVALIAÇÃO

ELETROMIOGRÁFICA DA CINTURA ESCAPULAR E MEMBRO SUPERIOR DURANTE

EXERCÍCIOS COM A EXTREMIDADE DISTAL FIXA E CARGA AXIAL"

Pesquisador responsável: Helga Tatiana Tucci

Orientadora Responável: Profa. Dra. Anamaria Siriani de Oliveira.

Eu,

portador do RG no:

residente à no

bairro

Cidade:

declaro que tenho

anos de idade e que concordo em participar, voluntariamente, na pesquisa conduzida pelos alunos responsáveis e por seu (sua) respectivo(a) orientador(a).

\section{Objetivo do Estudo:}

O objetivo deste trabalho será avaliar e comparar a atividade eletromiográfica dos músculos que serão estudados, ou seja, captar a atividade elétrica normal existente nos músculos através da colocação de eletrodos na pele (pequenas placas de metal que não machucam, não causam dor e não dão choque) durante a realização de 3 diferentes exercícios para o membro superior (braço e antebraço).

\section{Explicação do Procedimento:}

Estou ciente que farei 3 exercícios usando roupas confortáveis e que os responsáveis pela pesquisa farão marcações em áreas do meu braço e antebraço para colocar eletrodos, que serão fixados com fita adesiva. Tenho conhecimento de que os pesquisadores depilarão com lâmina de barbear e limparão com álcool minha pele no local de colocação dos eletrodos. Também estou ciente que não serei submetido a nenhum tipo de tratamento sem ter conhecimento ou sem meu consentimento e posso me desligar desta pesquisa a qualquer momento, me comprometendo somente a comunicar pelo menos um dos responsáveis por esta pesquisa.

\section{Possíveis Benefícios:}

Estou ciente que não existem benefícios diretos para minha pessoa devido à participação nesta pesquisa e que os dados obtidos pelos responsáveis auxiliaram no maior conhecimento a respeito dos exercícios estudados e na investigação de métodos de avaliação fisioterápicos capazes de auxiliar futuramente outros pesquisadores nesta área e os pacientes que vierem a utilizar estes exercícios. 


\section{Desconforto e risco:}

Fui informado que este experimento não trará nenhum tipo de desconforto ou risco a minha saúde e que minha identidade será mantida em sigilo absoluto.

\section{Seguro de Saúde ou de Vida:}

Eu entendo que não existe nenhum tipo de seguro de saúde ou de vida que possa vir a me beneficiar em função de minha participação neste estudo.

\section{Liberdade de Participação:}

A minha participação neste estudo é voluntária. É meu direito interromper minha participação a qualquer momento sem que isso incorra em qualquer penalidade ou prejuízo à minha pessoa. Também entendo que o pesquisador tem o direito de excluir meus dados deste estudo no caso de abandono do experimento, coleta incompleta ou conduta inadequada durante o período de coleta.

\section{Sigilo de I dentidade:}

As informações obtidas nesta pesquisa não serão de maneira alguma associadas a minha identidade e não poderão ser consultadas por pessoas leigas sem minha autorização oficial. Estas informações poderão ser utilizadas para fins estatísticos ou científicos, desde que fique resguardados a minha total privacidade e meu anonimato.

Para questões relacionadas a este estudo, contate:

Profa. Dra. Anamaria Siriani de Oliveira ou Helga Tatiana Tucci Curso de Fisioterapia - Faculdade de Medicina de Ribeirão Preto - FMRP-USP

Fone: (0XX16) 3602-4413

e-mail: siriani@fmrp.usp.br; helgatucci@yahoo.com.br

Os responsáveis pelo estudo me explicarão todos os riscos envolvidos, a necessidade da pesquisa e se prontificaram a responder todas as minhas questões sobre o experimento. Eu aceitei participar deste estudo de livre e espontânea vontade. Entendo que é meu direito manter uma cópia deste consentimento.

Ribeirão Preto, de de 200

Assinatura do Voluntário:

Helga Tatiana Tucci

Pesquisadora Responsável
Profa Dra Anamaria Siriani de Oliveira Orientadora Responsável 


\section{APÊNDI CE C - Ficha de Avaliação}

Nome:

Endereço:

Cidade:

Data de Nascimento:

Estado:

___ Profissão:

Data: __ _ _

Telefone:

Sexo: ( ) M ( ) F Idade:

Peso: $\mathrm{Kg}$

Altura:

Dominância: ( ) Destro ( ) Canhoto

Cor:

$\mathrm{cm}$

\begin{tabular}{|l|l|l|l|l|l|l|l|l|}
\hline \multicolumn{7}{|c|}{ Avaliação da Amplitude de Movimento Passiva (em graus) } \\
\hline Ombro & D & E & Cotovelo & D & E & $\begin{array}{l}\text { Punho } \\
\text { Direito }\end{array}$ & D & E \\
\hline Flexão & & & Flexão & & & Flexão & & \\
\hline Extensão & & Extensão & & & Extensão & & \\
\hline Abdução & & & Pronação & & & Desvio Radial & & \\
\hline Rotação E & & Supinação & & & Desvio Ulnar & & \\
\hline Rotação I & & & & & & & & \\
\hline
\end{tabular}

\begin{tabular}{|l|l|l|l|l|l|l|l|l|}
\hline \multicolumn{7}{|c|}{ Avaliação da Amplitude de Movimento Ativa (em graus) } \\
\hline Ombro & D & E & $\begin{array}{l}\text { Cotovelo } \\
\text { Direito }\end{array}$ & D & E & $\begin{array}{l}\text { Punho } \\
\text { Direito }\end{array}$ & D & E \\
\hline Flexão & & & Flexão & & & Flexão & & \\
\hline Extensão & & & Extensão & & & Extensão & & \\
\hline Abdução & & & Pronação & & & Desvio Radial & & \\
\hline Rotação E & & & Supinação & & & Desvio Ulnar & & \\
\hline Rotação I & & & & & & & & \\
\hline
\end{tabular}

\begin{tabular}{|c|c|c|c|}
\hline \multicolumn{4}{|c|}{ Testes Específicos } \\
\hline Ombro & Ombro & Cotovelo & Punho \\
\hline Neer: D ( ) E ( ) & Teste do Sulco: D( ) E ( ) & Epicondilite Medial: & Teste de \\
\hline Geber:D（ ）E（） & Rocwood: D（）E（） & $\mathrm{D}(\mathrm{l}) \mathrm{E}(\mathrm{l})$ & $\begin{array}{ll}D(\quad) \\
E(\end{array}$ \\
\hline Jobe: $\mathrm{D}(\mathrm{)}) \mathrm{E}(\mathrm{)}$ & Yegarson: D ( ) E ( ) & Epicondilite Lateral: & \\
\hline Hawkins: D ( ) E ( ) & & $D(\quad) \quad E(\quad)$ & \\
\hline & & $\begin{array}{l}\text { Estabilidade } \\
\text { Ligamentar: } \\
\text { D( ) E ( ) }\end{array}$ & \\
\hline
\end{tabular}

\begin{tabular}{|c|c|c|c|c|c|}
\hline \multicolumn{7}{|c|}{ Teste de Força Muscular } \\
\hline Braço & D & E & Braço & D & E \\
\hline Bíceps Braquial & & & $\begin{array}{c}\text { Trapézio } \\
\text { Superior }\end{array}$ & & \\
\hline $\begin{array}{c}\text { Deltóide } \\
\text { Anterior }\end{array}$ & & & Serrátil Anterior & & \\
\hline Peitoral Maior & & & Tríceps Braquial & & \\
\hline Punho & D & E & Punho & D & E \\
\hline Grupo Flexor & & & Grupo Extensor & & \\
\hline
\end{tabular}




\begin{tabular}{|r|r|r|r|r|r|}
\hline \multicolumn{7}{|c|}{ Comprimento do Segmento ( cm) } \\
\hline Braço D & Braço E & Antebraço D & Antebraço E & Mão D & Mão E \\
\hline $\mathrm{cm}$ & $\mathrm{cm}$ & $\mathrm{cm}$ & $\mathrm{cm}$ & $\mathrm{cm}$ & $\mathrm{cm}$ \\
\hline
\end{tabular}

- Comprimento do braço: medida realizada entre o acrômio e o epicôndilo lateral do úmero

- Comprimento do antebraço: medida realizada entre o epicôndilo lateral do úmero e o processo estilóide do rádio

- Comprimento da mão: medida realizada entre o terço medial da prega de flexão do punho e a extremidade distal do dedo médio

Observações: 


\section{HOSPITAL DAS CLÍNICAS DA FACULDADE DE MEDICINA} DE RIBEIRÃO PRETO DA UNIVERSIDADE DE SÃO PAULO

Ribeirão Preto, 20 de novembro de 2003

Oficio $n^{\circ} 3456 / 2003$

$\mathrm{CEP} / \mathrm{CDGC}$

Prezada Senhora:

O trabalho intitulado "AVALIAÇÃO

ELETROMIOGRÁFICA DA CINTURA ESCAPULAR E MEMBRO SUPERIOR DURANTE EXERCÍCIOS COM A EXTREMIDADE DISTAL FIXA E CARGA AXIAL", foi analisado pelo Comitê de Ética em Pesquisa, em sua $169^{a}$ Reunião Ordinária realizada em $17 / 11 / 2003$, e enquadrado na categoria: APROVADO, de acordo com o Processo HCRP $\mathrm{n}^{\circ} 10201 / 2003$.

Aproveito a oportunidade para apresentar a Vossa Senhoria protestos de estima e consideração.

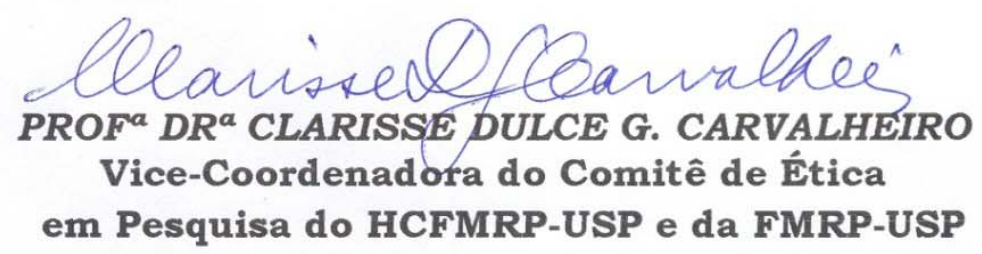

Ilustríssima Senhora

HELGA TATIANA TUCCI

PROF $^{a}$ DR $^{a}$ ANAMARIA SIRIANI DE OLIVEIRA (Orientadora)

Depto. de Biomecânica, Medicina e Reabilitação do Aparelho Locomotor Em mãos 